In cooperation with the Wisconsin Department of Natural Resources and the Minnesota Pollution Control Agency

\title{
Concentrations of Polycyclic Aromatic Hydrocarbons (PAHs) in Urban Stormwater, Madison, Wisconsin, 2005-08
}

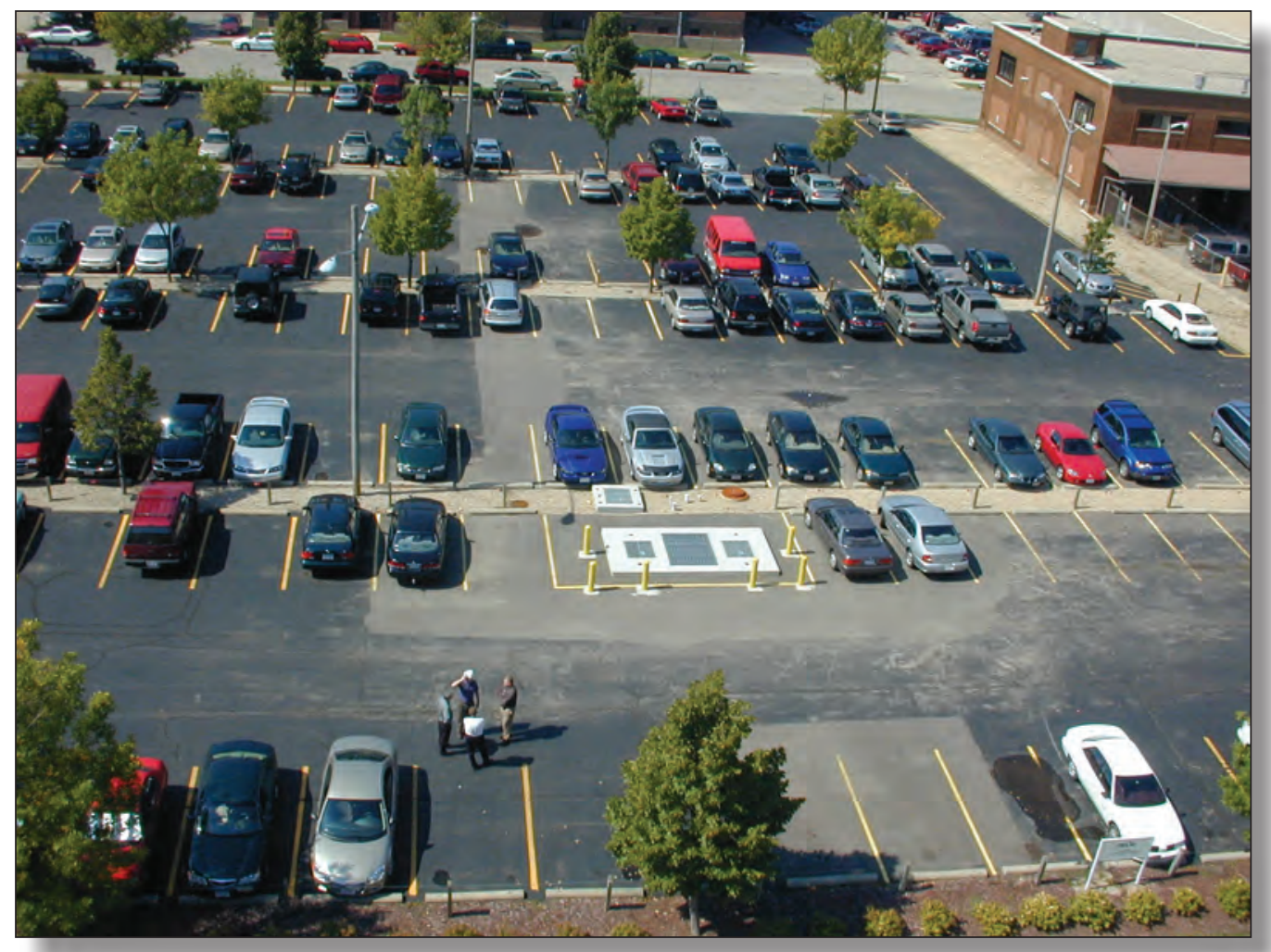

Open-File Report 2009-1077 



\section{Concentrations of Polycyclic Aromatic Hydrocarbons (PAHs) in Urban Stormwater, Madison, Wisconsin, 2005-08}

By William R. Selbig

In cooperation with the Wisconsin Department of Natural Resources and the Minnesota Pollution Control Agency

Open-File Report 2009-1077 


\title{
U.S. Department of the Interior \\ KEN SALAZAR, Secretary
}

\author{
U.S. Geological Survey \\ Suzette M. Kimball, Acting Director
}

U.S. Geological Survey, Reston, Virginia: 2009

For more information on the USGS—-the Federal source for science about the Earth, its natural and living resources,
natural hazards, and the environment, visit http://www.usgs.gov or call 1-888-ASK-USGS
For an overview of USGS information products, including maps, imagery, and publications,
visit http://www.usgs.gov/pubprod
To order this and other USGS information products, visit http://store.usgs.gov

Any use of trade, product, or firm names is for descriptive purposes only and does not imply endorsement by the U.S. Government.

Although this report is in the public domain, permission must be secured from the individual copyright owners to reproduce any copyrighted materials contained within this report.

Suggested citation:

Selbig, W.R., 2009, Concentrations of polycyclic aromatic hydrocarbons (PAHs) in urban stormwater,

Madison, Wisconsin, 2005-08: U.S. Geological Survey Open-File Report 2009-1077, 46 p. 


\section{Contents}

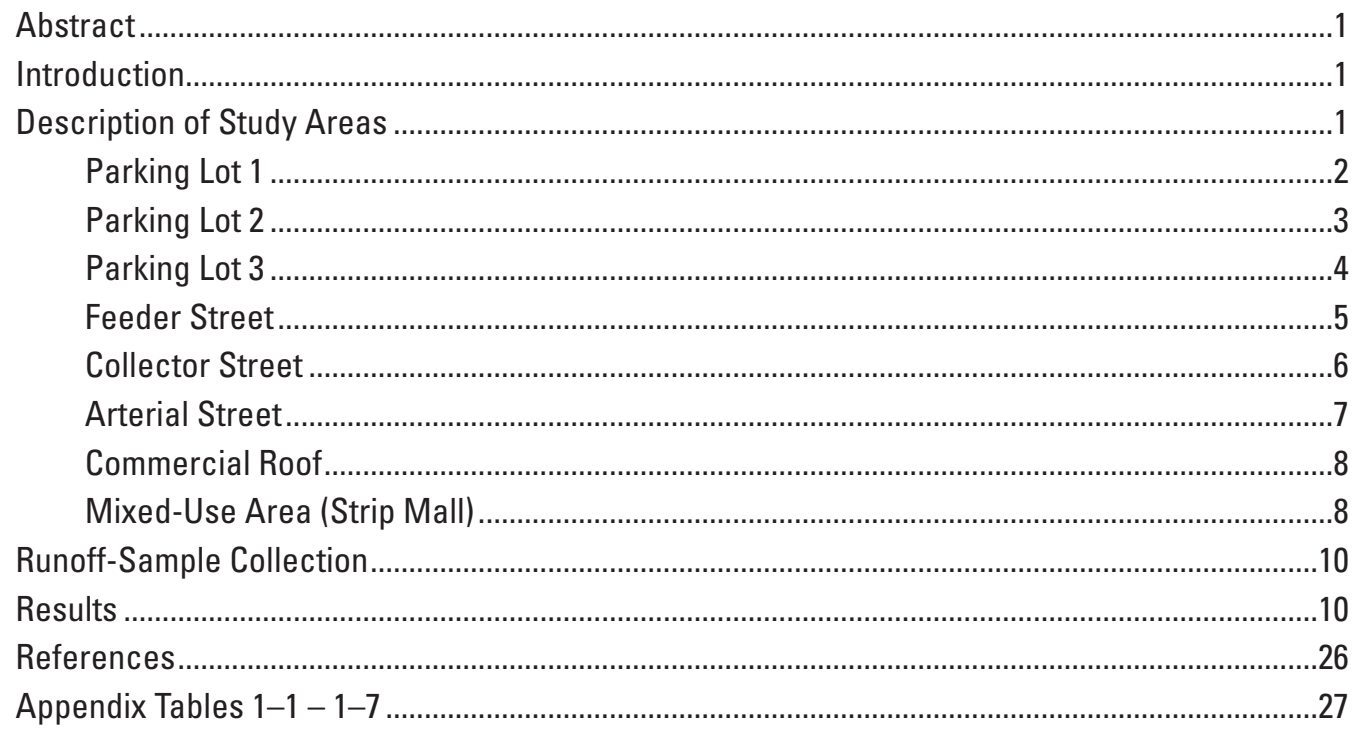

\section{Figures}

1-8. Photographs showing:

1. Parking lot number 1. A, Ground-level view. $B$, Aerial view with delineated

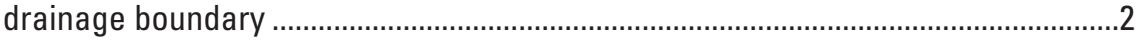

2. Parking lot number 2. $A$, Ground-level view. $B$, Aerial view with delineated drainage boundary .....

3. Parking lot number 3. $A$, Ground-level view. $B$, Aerial view with delineated drainage boundary ............................................................................................... 4

4. Photograph of feeder street, Madison, Wis. ........................................................... 5

5. Photograph of collector (minor arterial) street, Middleton, Wis. ...............................6

6. Arterial street. $A$, Ground-level view. $B$, Aerial view with delineated drainage boundary

7. Photograph of commercial roof, Madison, Wis. .......................................................8

8. Mixed use (strip mall) study site, Fitchburg, Wis. A, Ground-level view. $B$, Aerial view with delineated drainage boundary..................................................

9-11. Graphs showing:

9. Percent contribution of individual PAH compounds from source areas monitored in Madison, Wis. (2008)......

10A. Geometric mean concentrations of polycyclic aromatic hydrocarbons from parking lots in Madison, Wis., and Marquette, Mich.

10B. Geometric mean concentrations of polycyclic aromatic hydrocarbons from commercial roofs in Madison, Wis., and Marquette, Mich.

10C. Geometric mean concentrations of polycyclic aromatic hydrocarbons from feeder streets in Madison, Wis., and Marquette, Mich.

10D. Geometric mean concentrations of polycyclic aromatic hydrocarbons from collector streets in Madison, Wis., and Marquette, Mich. 
10E. Geometric mean concentrations of polycyclic aromatic hydrocarbons from arterial streets in Madison, Wis., and Marquette, Mich.

10F. Geometric mean concentrations of total polycyclic aromatic hydrocarbons from source areas monitored in Madison, Wis., and Marquette, Mich.

11. Mean concentration of total polycyclic aromatic hydrocarbons from source areas monitored in Madison, Wis. (2008)

\section{Tables}

1. Source areas and land uses sampled for definition of pollutant concentration................1

2. Limits of detection and detection frequencies of polycyclic aromatic hydrocarbons

$3 A$. Summary statistics of polycyclic aromatic hydrocarbons for parking lots that have and have not been sealed

$3 B$. Summary statistics of polycyclic aromatic hydrocarbons for residential feeder street.

3C. Summary statistics of polycyclic aromatic hydrocarbons for collector street................16

3D. Summary statistics of polycyclic aromatic hydrocarbons for arterial street...................17

$3 E$. Summary statistics of polycyclic aromatic hydrocarbons for commercial roof.............18

3F. Summary statistics of polycyclic aromatic hydrocarbons for the mixed-use area (strip mall)

\section{Conversion Factors and Abbreviations}

\begin{tabular}{lll}
\hline \multicolumn{1}{c}{ Multiply } & By & \multicolumn{1}{c}{ To obtain } \\
\hline inch (in.) & Length & \\
foot (ft) & 2.54 & centimeter $(\mathrm{cm})$ \\
& 0.3048 & meter $(\mathrm{m})$ \\
\hline acre & Area & \\
square foot $\left(\mathrm{ft}^{2}\right)$ & 0.4047 & hectare $(\mathrm{ha})$ \\
\hline & 0.09290 & square meter $\left(\mathrm{m}^{2}\right)$ \\
\hline liter (L) & Volume & \\
\hline
\end{tabular}

Temperature in degrees Celsius $\left({ }^{\circ} \mathrm{C}\right)$ may be converted to degrees Fahrenheit $\left({ }^{\circ} \mathrm{F}\right)$ as follows ${ }^{\circ} \mathrm{F}=\left(1.8 \times^{\circ} \mathrm{C}\right)+32$

Horizontal coordinate information is referenced to the 1991 adjustment of the North American Datum of 1983 (NAD 83/91).

Water year in USGS reports is the 12-month period October 1 through September 30. The water year is designated by the calendar year in which it ends. 


\title{
Concentrations of Polycyclic Aromatic Hydrocarbons (PAHs) in Urban Stormwater, Madison, Wisconsin, 2005-08
}

\author{
By William R. Selbig
}

\begin{abstract}
Concentrations of $18 \mathrm{PAH}$ compounds were characterized from six urban source areas (parking lots, feeder street, collector street, arterial street, rooftop, and strip mall) around Madison, Wisconsin. Parking lots were categorized into those that were or were not sealed. On average, chrysene, fluoranthene, and pyrene were the dominant PAH compounds in all urban stormwater samples. Geometric mean concentrations for most individual PAH compounds were significantly greater for a parking lot that was sealed than for lots that were not sealed. Results from this study are consistent with similar studies that measured PAH concentrations in urban stormwater samples in Marquette, Mich., and Madison, Wis.
\end{abstract}

\section{Introduction}

Environmental managers are often faced with the difficult challenge of developing strategies to mitigate a variety of pollutants entrained in urban runoff. Characterizing pollutant concentrations by source area may help focus managerial decision-making. Limited attention has been given to more unconventional and potentially toxic pollutants, such as polycyclic aromatic hydrocarbons (PAHs), owing to a lack of concentration data. Although there is growing evidence that PAHs and other organic pollutants are degrading the health of urban water resources, not enough data are available to do a mass balance on their sources.

In 2005, the U.S. Geological Survey (USGS), in cooperation with the Wisconsin Department of Natural Resources (WDNR), began a study to help municipalities reduce the uncertainty in their stormwater management planning by characterizing polycyclic aromatic hydrocarbon (PAH) concentrations in urban runoff from different source areas and land uses. As part of an interstate cooperative agreement, the Minnesota Pollution Control Agency (MPCA) joined the study in 2008. Water-quality samples were collected at multiple sites in Madison, Wis., for approximately 1 year at each site; the entire study spanned August 2005 through September 2008. The purpose of this report is to summarize PAH concentration data collected from six urban source areas in or near Madison, Wis., during the study and to compare these data to PAH concentrations reported in previous studies.

\section{Description of Study Areas}

This study characterized concentrations of individual PAH compounds as well as a total PAH summation from several urban source areas. Specific source areas and land-use categories are identified in table 1. Choice of these urban source areas was based on the prevalence of the specific types of source areas within urban watersheds. Data from source areas or land uses with multiple sampling locations were synthesized to represent their respective category. For example, data from three different commercial parking lots were synthesized into a single dataset representing all parking lots. Parking lots were further delineated by maintenance criteria as being either sealed or not sealed with an asphalt or coal-tar-based sealant. Each street was categorized by traffic volume as a feeder, collector, or arterial street. A summary of the geographic setting and physical description for each study area follows.

Table 1. Source areas and land uses sampled for definition of pollutant concentration.

\begin{tabular}{llc}
\hline \multicolumn{1}{c}{ Source area } & \multicolumn{1}{c}{ Land use } & Number of sites \\
\hline Parking lot & Commercial & 3 \\
Streets & $\begin{array}{c}\text { Residential, } \\
\text { commercial }\end{array}$ & 3 \\
Rooftop & $\begin{array}{c}\text { Institutional (flat) } \\
\text { Commercial } \\
\text { (strip mall) }\end{array}$ & 1 \\
Mixed use & not sealed) \\
\hline
\end{tabular}




\section{Parking Lot 1}
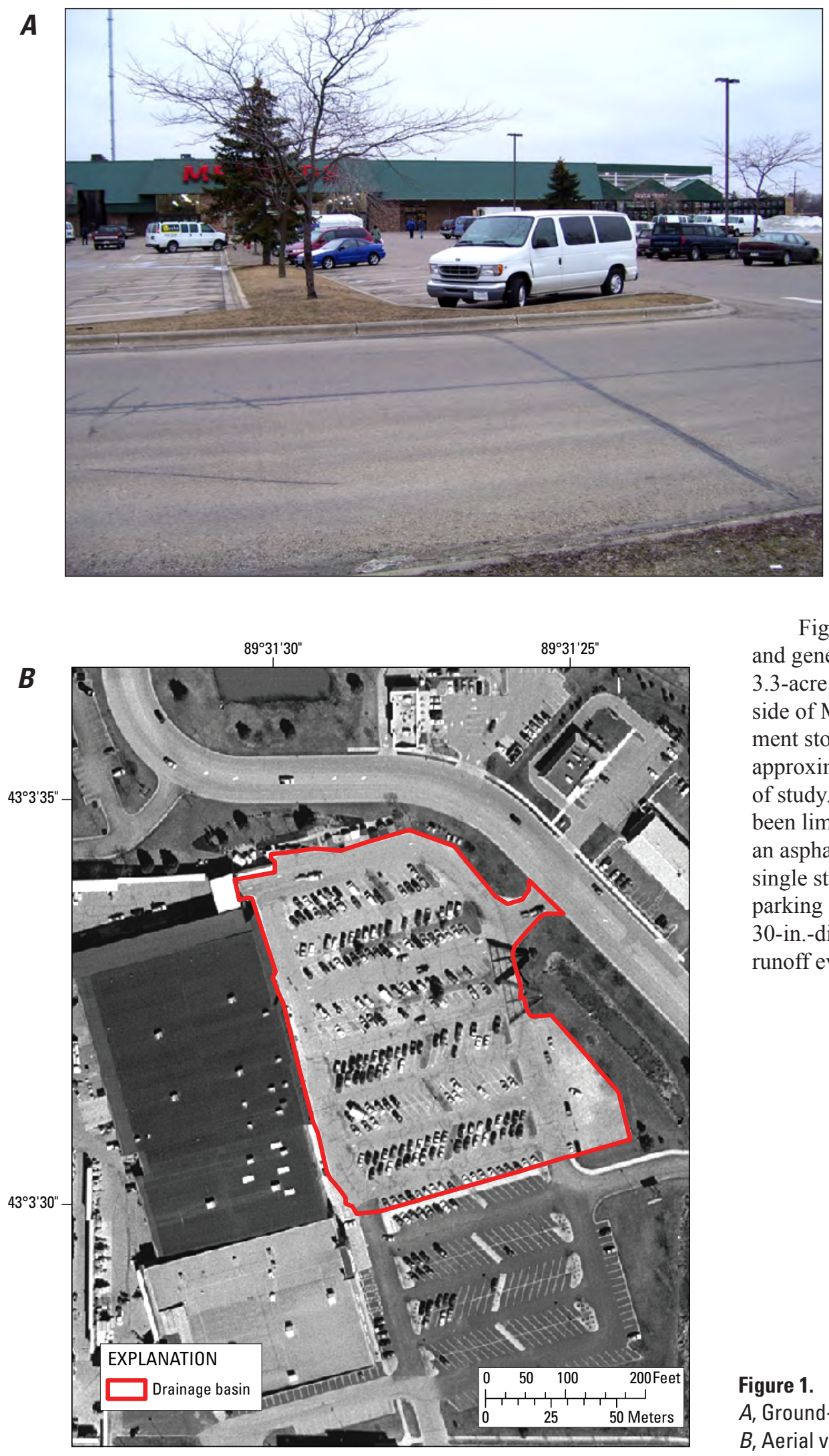

Figures $1 A$ and $1 B$ illustrate the layout and general appearance of parking lot 1 . This 3.3-acre commercial parking area is on the west side of Madison adjacent to a home improvement store. The asphalt-based surface was approximately 10 to 15 years old at the time of study. Maintenance of the asphalt lot has been limited to periodic sealing of cracks with an asphalt-based tar. Runoff is collected into a single storm-sewer inlet near the center of the parking lot, then conveyed through a concrete, 30-in.-diameter circular pipe from which the runoff eventually drains into an open ditch.

Figure 1. Parking lot number 1.

$A$, Ground-level view.

$B$, Aerial view with delineated drainage boundary. 


\section{Parking Lot 2}
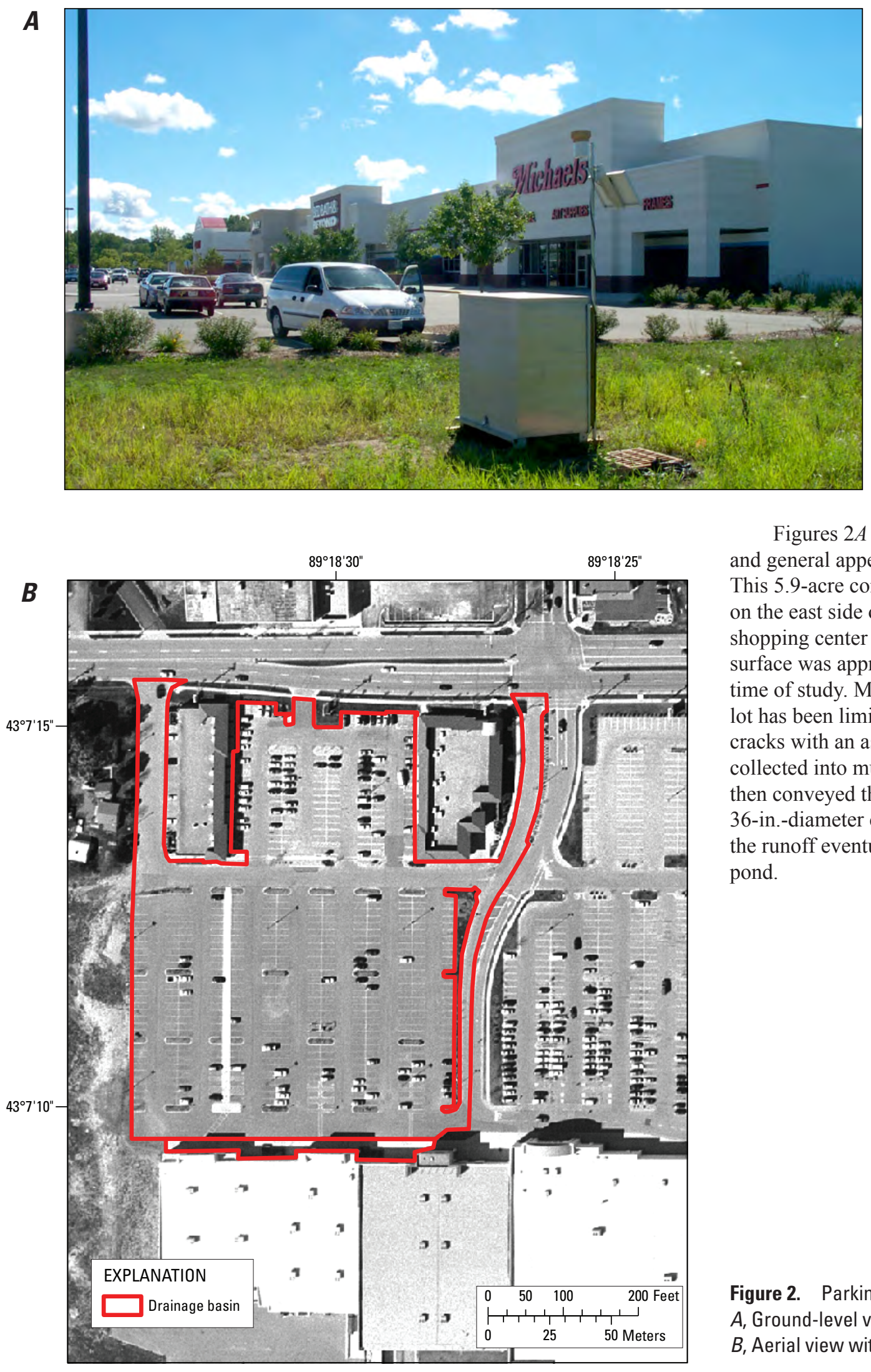

Figures $2 A$ and $2 B$ illustrate the layout and general appearance of parking lot 2 . This 5.9-acre commercial parking area is on the east side of Madison adjacent to a shopping center complex. The asphalt-based surface was approximately 5 years old at the time of study. Maintenance of the asphalt lot has been limited to periodic sealing of cracks with an asphalt-based tar. Runoff is collected into multiple storm-sewer inlets then conveyed through a common concrete, 36-in.-diameter circular pipe, from which the runoff eventually drains into a detention pond.

Figure 2. Parking lot number 2.

$A$, Ground-level view.

$B$, Aerial view with delineated drainage boundary. 


\section{Parking Lot 3}

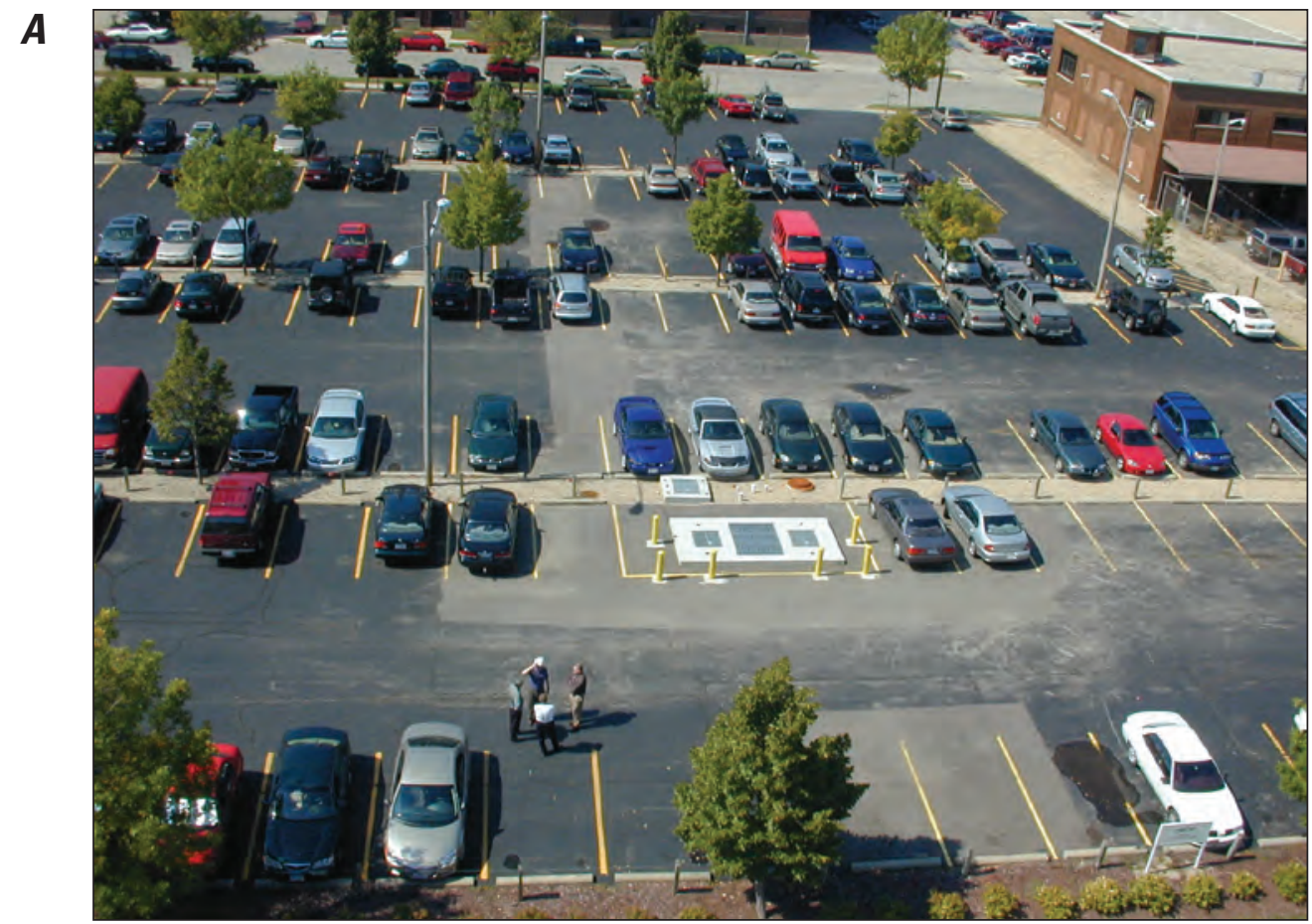

Figures $3 A$ and $3 B$ illustrate the layout and general

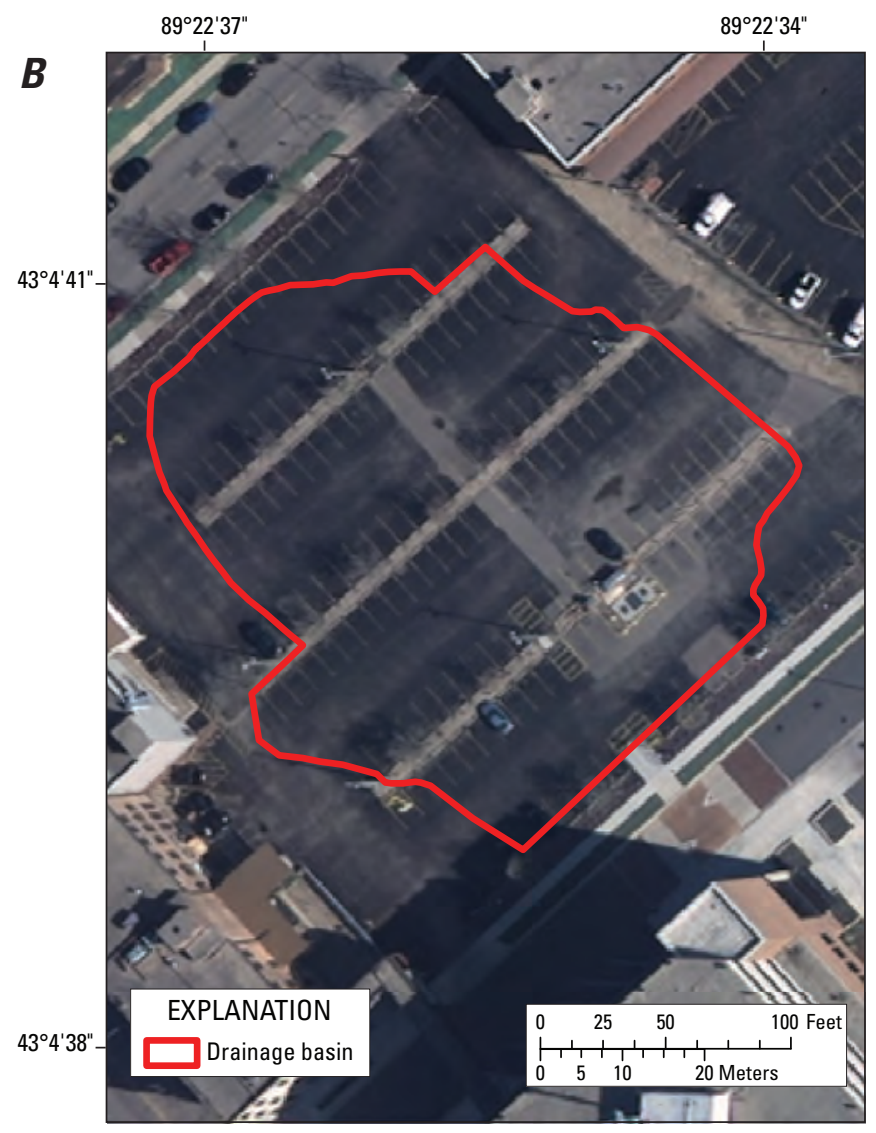
appearance of parking lot 3 . This 0.91 -acre parking lot is used primarily for employees of an electric generation plant during weekdays and as overflow parking for nearby businesses during weeknights and weekends (Judy Horwatich, U.S. Geological Survey, written commun., 2009). The asphalt-based surface was 22 years old at the time of study. Maintenance for the parking lot includes periodic application of seal coat. A seal coat of coal-tar was last applied in 2000.

Figure 3. Parking lot number 3 . $A$, Ground-level view. $B$, Aerial view with delineated drainage boundary. 


\section{Feeder Street}

This 0.4 -acre residential street had an average daily traffic count of fewer than 1,500 vehicles per day at the time of study. Runoff from the asphalt-based street is collected via concrete curb and gutter and conveyed into a nearby storm sewer. Runoff is from the street surface with no additional contributing source areas. A moderate amount of organic detritus is deposited on the street surface from overhead tree canopy, especially during spring and fall. The street was cleaned monthly during the study period, commencing in early spring and ending in late fall. Figure 4 shows the general appearance of the residential feeder street.

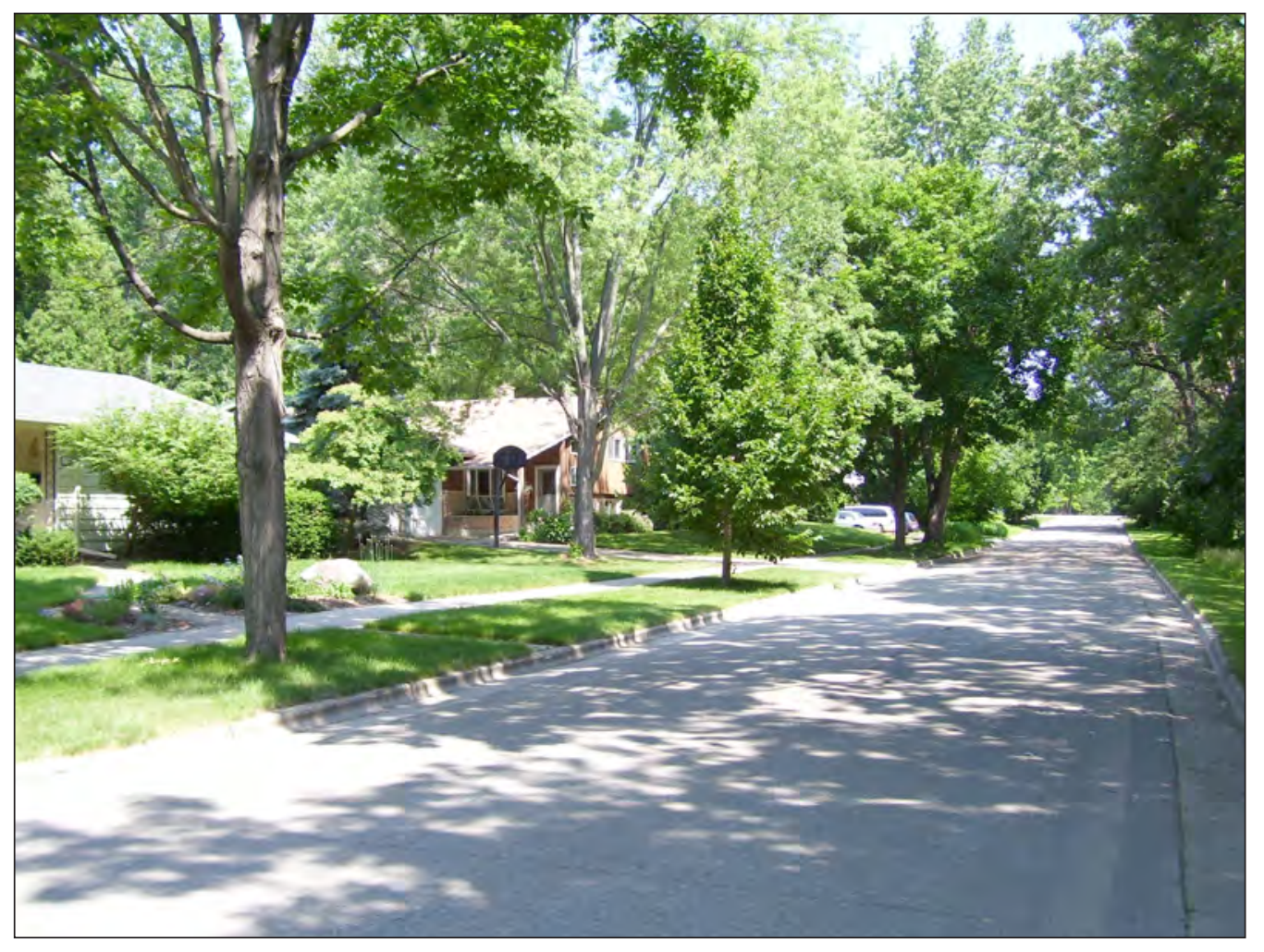

Figure 4. Feeder street, Madison, Wis. 


\section{Collector Street}

This 0.93 -acre commercial street had an average daily traffic count ranging between 10,000 to 15,000 vehicles per day at the time of study, designating it as a collector to minor arterial street. Runoff from the asphalt-based street is collected from two lanes of asphalt pavement in both the eastbound and westbound directions via concrete curb and gutter and then conveyed into a concrete, 15 -in.-diameter circular pipe. Streets are the major source of runoff; even though a grassed median separates the eastbound and westbound lanes, it was not considered a significant source of runoff. The street was cleaned monthly during the study period, commencing in early spring and ending in late fall. Figure 5 shows the general appearance of the collector street.

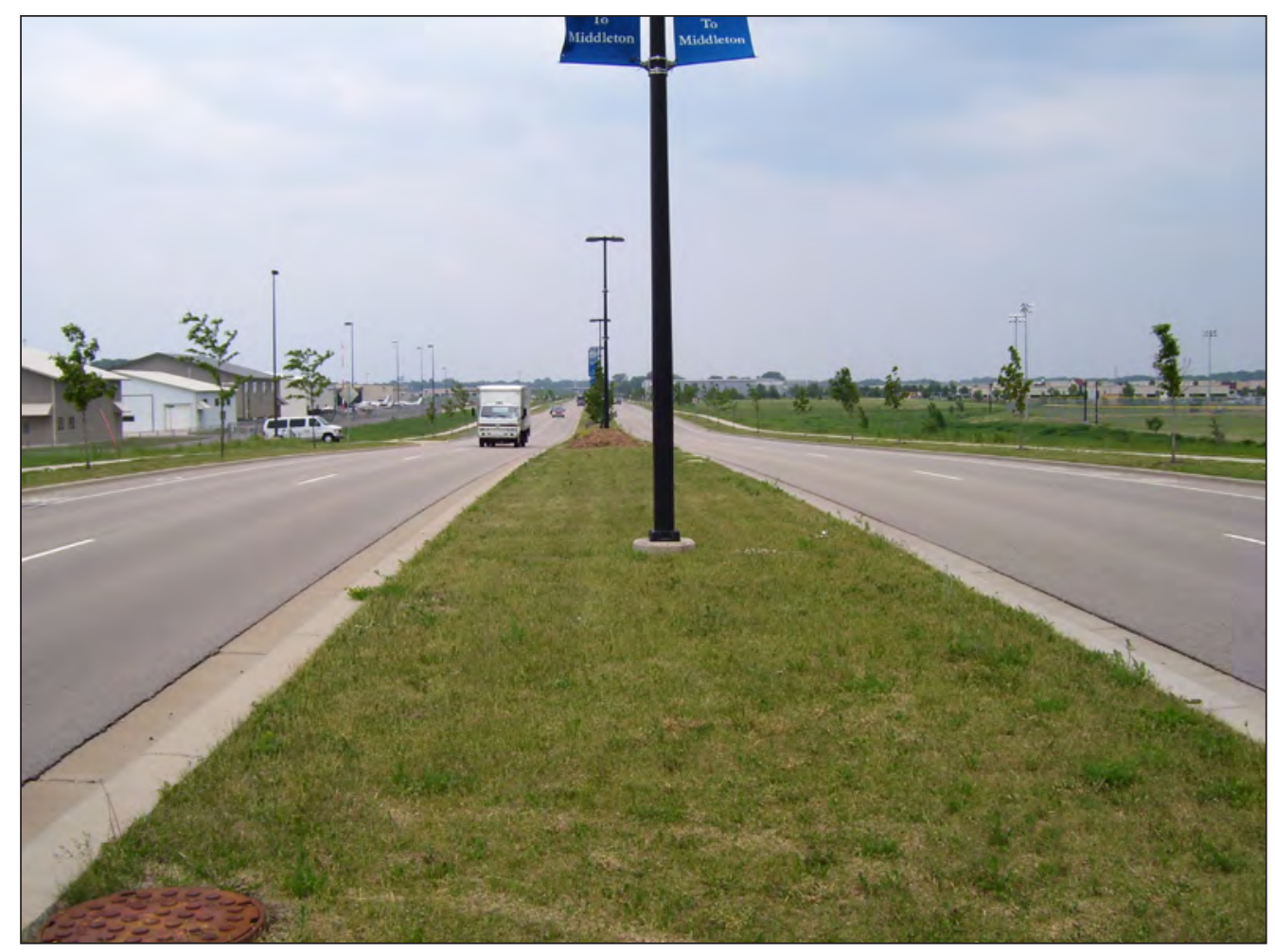

Figure 5. Collector (minor arterial) street, Middleton, Wis. 


\section{Arterial Street}

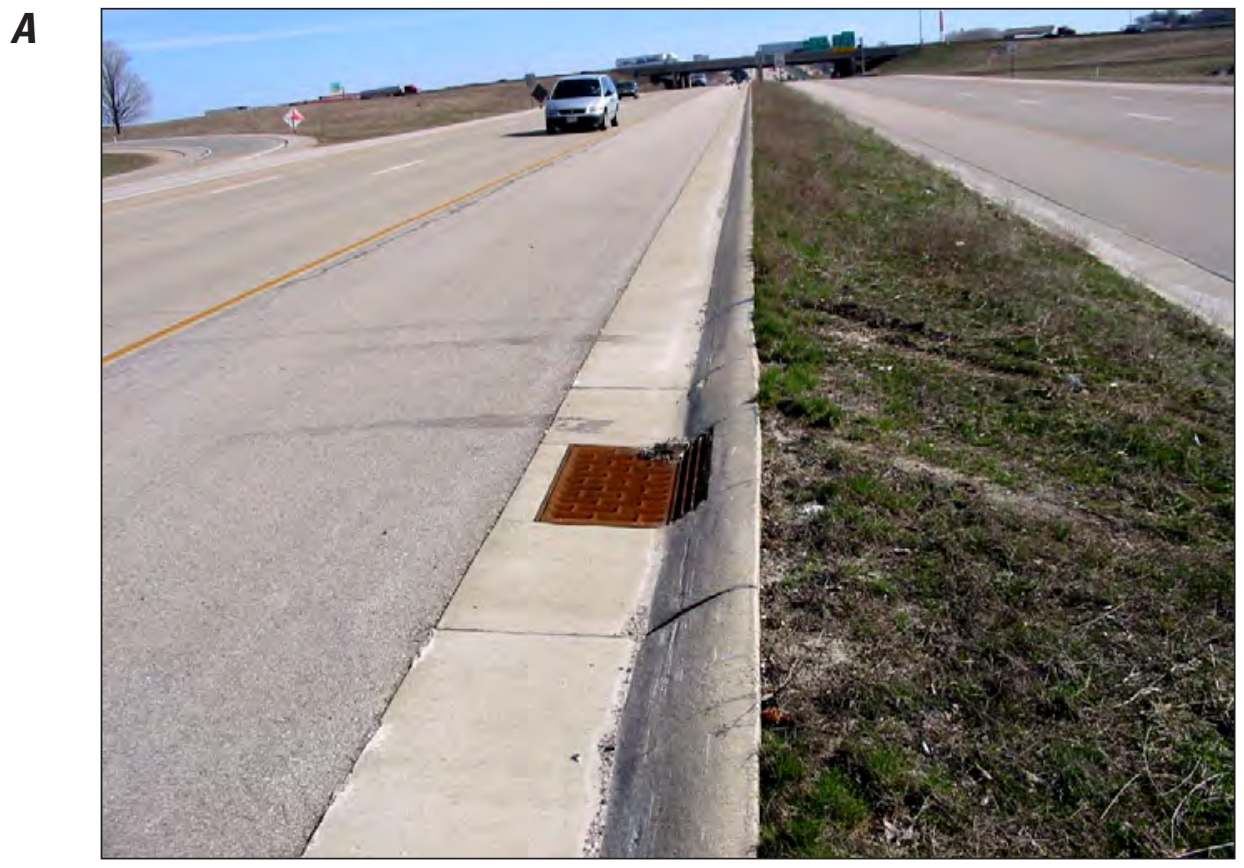

\section{B}

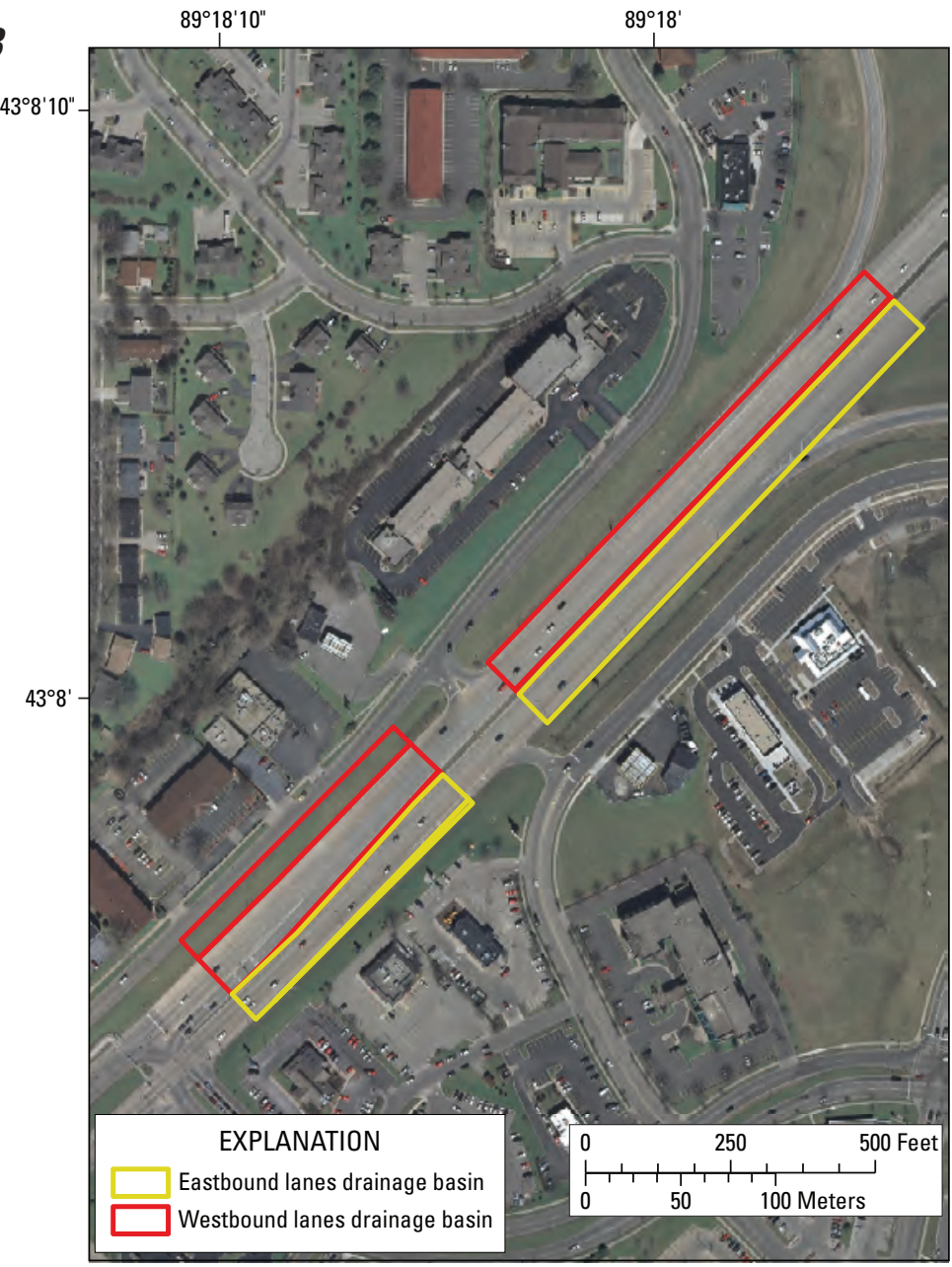

The arterial street is a length of U.S. Highway 151 in Madison, Wis. It was reconstructed in 1999 as divided highway with up to four lanes in each direction. The monitored stretch of highway has a drainage area of 2.27 acres and approximately 5,000 linear feet of curb and gutter that directs highway runoff into a concrete, 18-in.-diameter circular pipe (Judy Horwatich, U.S. Geological Survey, written commun., 2009). A 3-ft-wide grassed median separates the eastbound and westbound lanes. Runoff from a small, grassy hillside drains to the arterial street but was not considered a significant source of flow (Judy Horwatich, U.S. Geological Survey, oral commun., 2009). The concrete-based highway has 1/8-in. grooves oriented perpendicular to traffic flow. These grooves provide pavement drainage and traction for vehicles under slippery conditions. Average daily traffic count was approximately 40,000 vehicles per day at the time of study. Figures $6 A$ and $6 B$ show the general appearance of the arterial street.
Figure 6. Arterial street. $A$, Ground-level view. $B$, Aerial view with delineated drainage boundary. 


\section{Commercial Roof}

The commercial roof monitored as part of this study is a municipal wellhouse on the west side of Madison, Wis. Runoff from the 3,080- $\mathrm{ft}^{2}$ flat, rubber roof is directed equally to one of two aluminum downspouts. Samples were acquired at the end of a single downspout. Figure 7 shows the general appearance of the commercial roof.

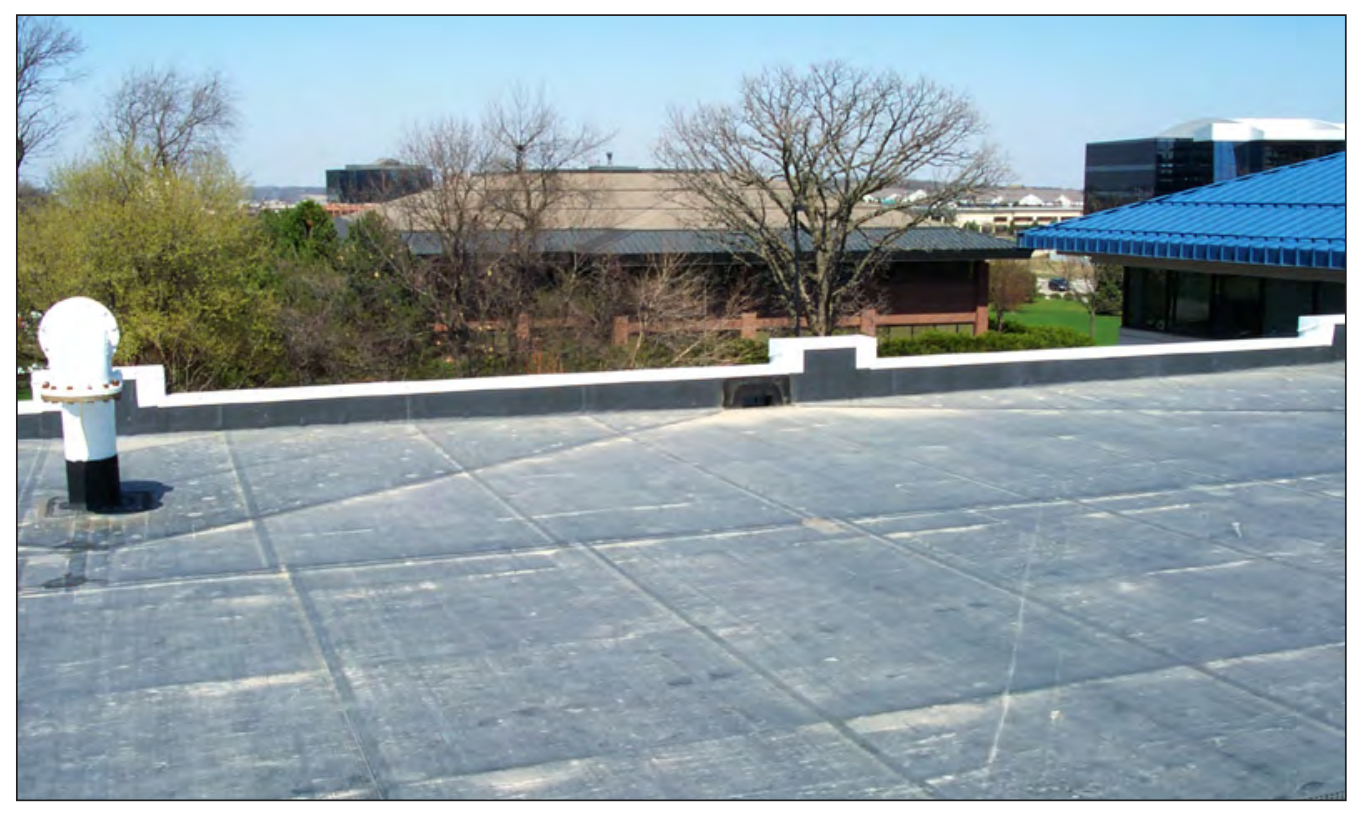

Figure 7. Commercial roof, Madison, Wis.

\section{Mixed-Use Area (Strip Mall)}

This 2.76-acre mixed-use area (representing the "strip mall" category sometimes used in urban stormwater studies and models) is in the City of Fitchburg, just south of Madison. Runoff originates from four primary source areas: parking lot (57 percent), roofs (24 percent), sidewalks (15 percent), and grassed areas (4 percent). Runoff is collected by multiple storm-sewer inlets and then conveyed through a single concrete, 12-in.-diameter circular storm sewer, from which the runoff eventually drains into an open ditch. Roofs within the strip-mall drainage basin are constructed primarily with asphalt composite shingles commonly found on residential dwellings. The gutters and downspouts are constructed primarily of painted extruded aluminum. The asphalt-based parking lot was approximately 10 years old at the time of study, having been constructed in 1999. Maintenance for the parking lot has included periodic application of seal coat. Sealant was last applied on July 16, 2008, at approximately halfway through the sampling timeframe of this study. It is unknown whether the sealant was asphalt or coal-tar based. Figures $8 A$ and $8 B$ show the general appearance and layout of the strip mall. 


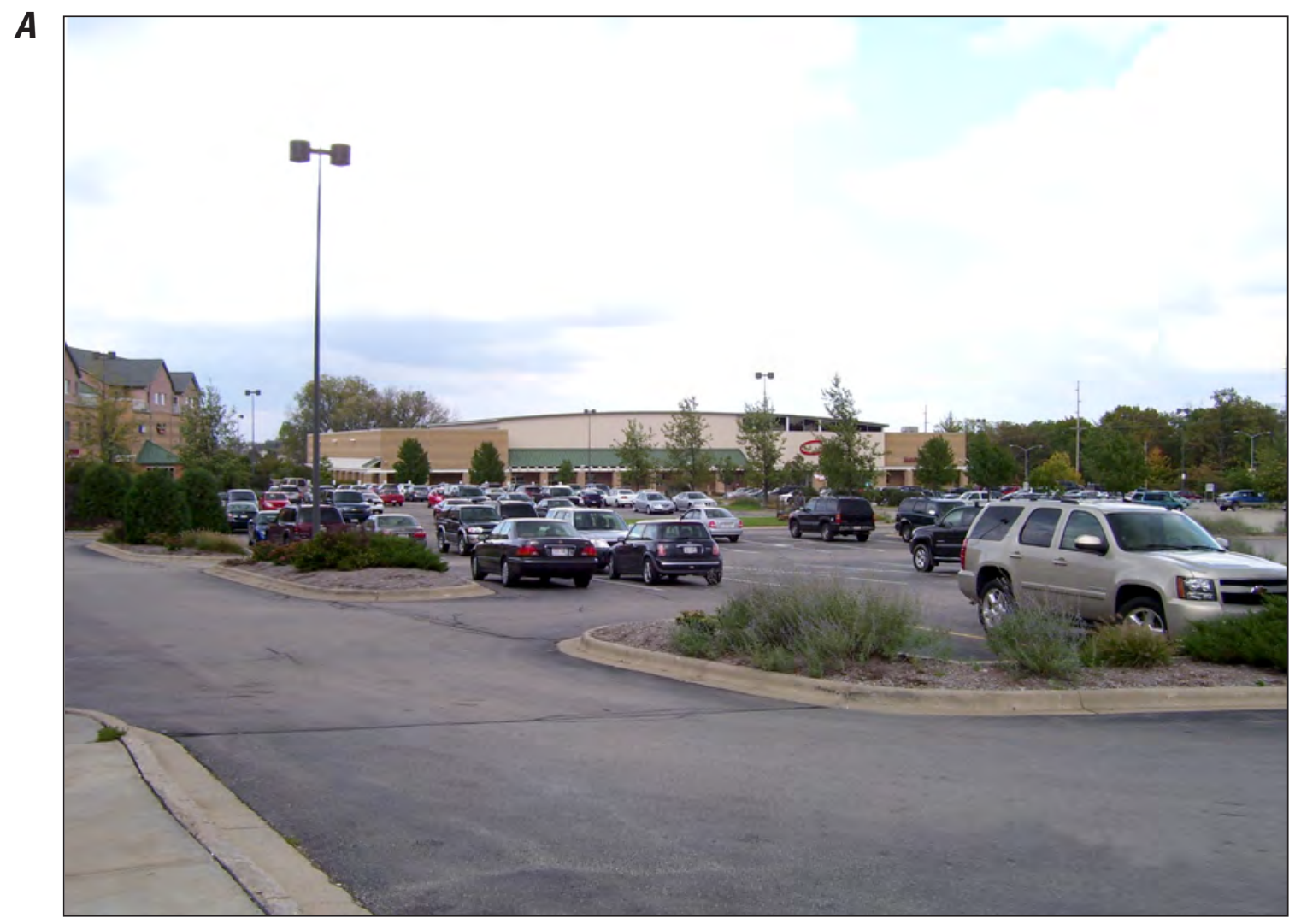

\section{B}

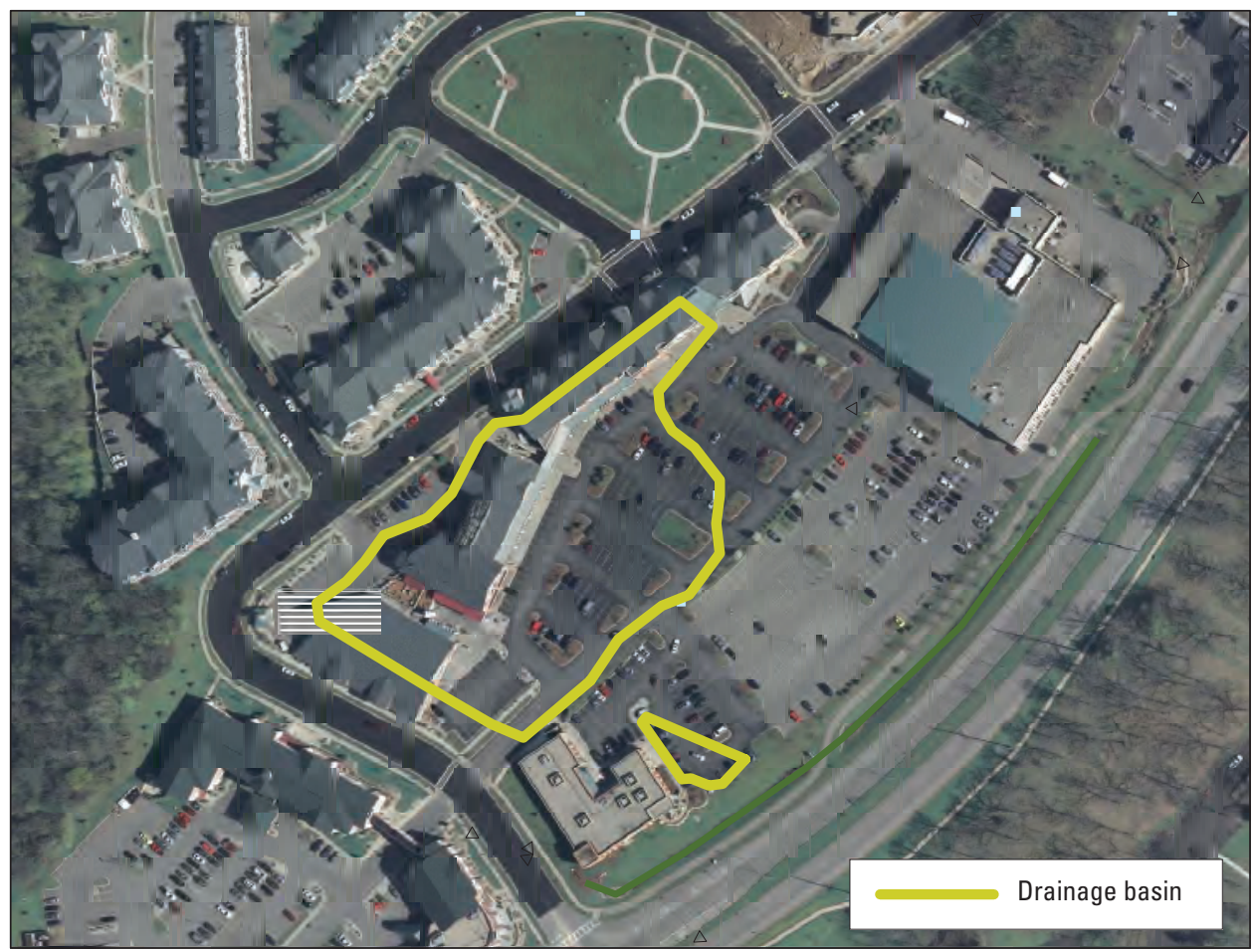

Figure 8. Mixed use (strip mall) study site, Fitchburg, Wis. $A$, Ground-level view.

$B$, Aerial view with delineated drainage boundary. 


\section{Runoff-Sample Collection}

An automated monitoring station was used to measure flow and collect samples near the basin outlet of each source area monitored in this study. Each monitoring station was equipped with automated stormwater-quality samplers and instruments to measure water level and velocity. Measurement, control, and storage of data were done by way of electronic dataloggers. Precipitation data were collected by use of a tipping-bucket rain gage calibrated to $0.01 \mathrm{inch}$. A probe with two different sensor systems was mounted to the bottom of each pipe. Each probe contained a pressure transducer to measure water level and a pair of ultrasonic transducers to measure velocity. A fifth-order polynomial was used to convert water level into cross-sectional area for each pipe configuration. Instantaneous pipe discharge was then computed by multiplying the cross-sectional area of the pipe by the associated mean velocity. Storm-runoff volumes were computed by summing the 1-minute-interval instantaneous discharge during the sampled storm.

Sample collection was activated by a rise in water level in the pipe during a precipitation event. Once the water-level threshold was exceeded, typically a depth of $0.15 \mathrm{ft}$ from the pipe floor, the volume of water passing the station was measured and accumulated at 1-minute increments until a volumetric threshold was reached. At that point, the sampler collected a discrete water sample and the volumetric counter was reset. The process was repeated until the water level receded below the threshold. The Teflon-lined intake nozzle of the sampler orifice was approximately $0.5 \mathrm{in}$. above the pipe floor. Subsamples, $1 \mathrm{~L}$ in volume, were transferred through the Teflon-lined sample tubing into a 10-L glass jar.

These flow-weighted samples were collected and composited into a single water sample, then split and processed for analysis. A Teflon churn splitter was used to composite and split samples into smaller, 1-L amber glass bottles for detection of PAH compounds. Processed samples were kept in a refrigerator at $4^{\circ} \mathrm{C}$ until delivered to the analytical laboratory, usually within 48 hours after runoff cessation. Because each discrete sample was composited into a single event sample, the resulting concentrations represent the event mean concentration (EMC). Samples were analyzed at the Wisconsin State Laboratory of Hygiene, in Madison.

\section{Results}

Table 2 lists individual PAH compounds for which samples were analyzed and the detection frequency for each source area or land use. The parking-lot source area was divided into lots that were or were not sealed with an asphalt or coal-tar-based sealant. A detection frequency of "none," "intermittent," or "common" indicates that concentrations in all, more than 50 percent, or fewer than 50 percent of the samples analyzed were below the detection limit for the corresponding PAH compound, respectively.

Of the 18 individual PAH compounds for which samples were analyzed, 6 were nearly always below the detection limit for all source areas monitored: acenaphthylene, dibenzo (A, H) anthracene, fluorene, 1-methylnaphthalene, 2-methylnaphthalene, and naphthalene. In most cases, individual PAH compounds that were never detected in runoff from the roof, the streets, or the mixed-use area were intermittently detected in runoff from parking lots. On average, chrysene, fluoranthene, and pyrene were the dominant PAH compounds in all urban stormwater samples (fig. 9). This finding is consistent with results from similar, previous studies that measured PAH concentrations in urban stormwater samples (Hoffman, 1985; Steuer and others, 1996,1997; Menzie and others, 2002; Stein and others, 2006 ). 
Table 2. Limits of detection and detection frequencies of polycyclic aromatic hydrocarbons.

$[\mu \mathrm{g} / \mathrm{L}$, micrograms per liter]

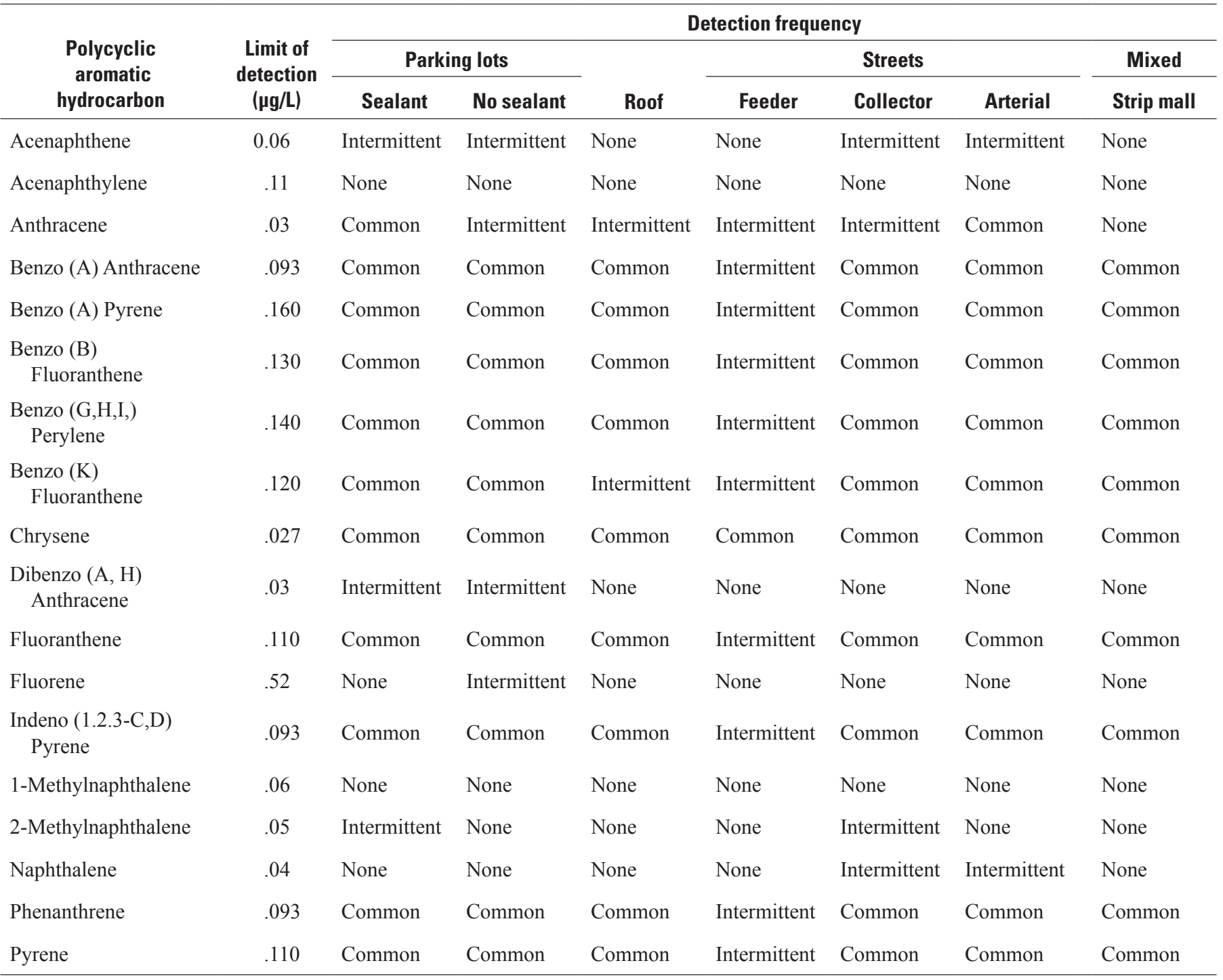




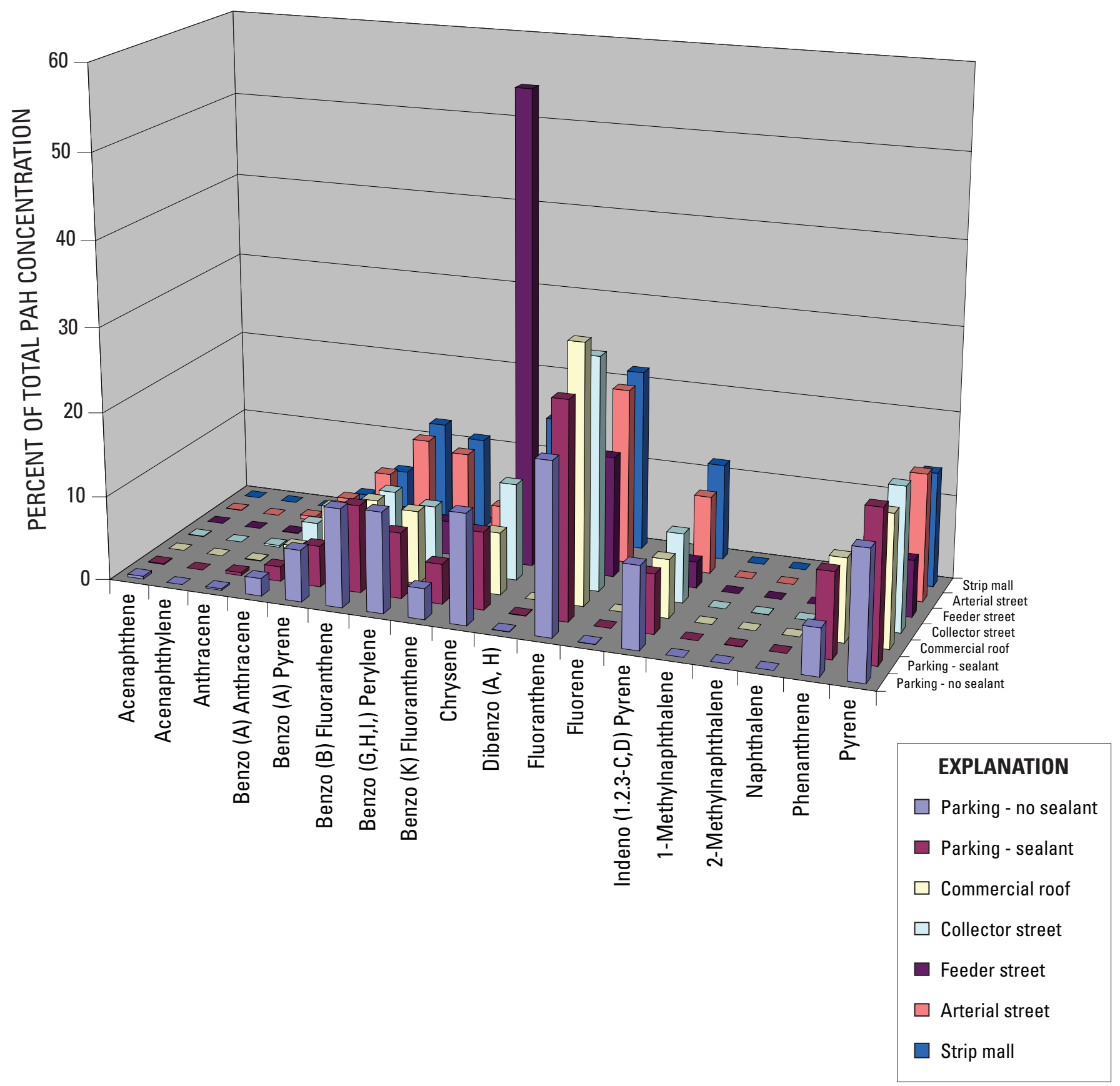

Figure 9. Percent contribution of individual PAH compounds from source areas monitored in Madison, Wis. (2008). 
Table 3A. Summary statistics of polycyclic aromatic hydrocarbons for parking lots that have and have not been sealed.

$[<$, less than; - , not determined; $\mu \mathrm{g} / \mathrm{L}$, micrograms per liter; chemical nomenclature is that of the Wisconsin State Laboratory of Hygiene $]$

\begin{tabular}{|c|c|c|c|c|c|c|c|c|}
\hline $\begin{array}{l}\text { Polycyclic aromatic } \\
\text { hydrocarbon }\end{array}$ & $\begin{array}{c}\text { Number of } \\
\text { observations }\end{array}$ & $\begin{array}{c}\text { Number } \\
\text { of } \\
\text { detections }\end{array}$ & $\begin{array}{l}\text { Minimum } \\
(\mu \mathrm{g} / \mathrm{L})\end{array}$ & $\begin{array}{l}\text { Maximum } \\
(\mu \mathrm{g} / \mathrm{L})\end{array}$ & $\begin{array}{l}\text { Median } \\
\text { ( } \mu \mathrm{g} / \mathrm{L})\end{array}$ & $\begin{array}{l}\text { Mean } \\
(\mu \mathrm{g} / \mathrm{L})\end{array}$ & $\begin{array}{l}\text { Standard } \\
\text { deviation }\end{array}$ & $\begin{array}{c}\text { Coefficient } \\
\text { of } \\
\text { variation }\end{array}$ \\
\hline Acenaphthene & 14 & 6 & $<.064$ & 0.17 & $<.064$ & 0.09 & 0.04 & 0.41 \\
\hline Acenaphthylene & 15 & 0 & $<0.11$ & $<0.11$ & $<0.11$ & - & - & - \\
\hline Benzo (A) Anthracene & 14 & 11 & 0.17 & 2.00 & 1.10 & 1.09 & 0.71 & 0.65 \\
\hline Benzo (A) Pyrene & 13 & 13 & 0.66 & 6.10 & 3.60 & 3.21 & 1.86 & 0.58 \\
\hline Benzo (B) Fluoranthene & 15 & 15 & 1.70 & 10.00 & 5.20 & 5.55 & 2.49 & 0.45 \\
\hline $\begin{array}{l}\text { Dibenzo }(\mathrm{A}, \mathrm{H}) \\
\text { Anthracene }\end{array}$ & 15 & 1 & $<0.12$ & 0.47 & $<0.12$ & - & - & - \\
\hline Fluoranthene & 15 & 15 & 3.70 & 25.00 & 13.00 & 13.81 & 6.17 & 0.45 \\
\hline Fluorene & 15 & 0 & $<0.52$ & $<0.52$ & $<0.52$ & - & - & - \\
\hline $\begin{array}{l}\text { Indeno (1.2.3-C,D) } \\
\quad \text { Pyrene }\end{array}$ & 15 & 15 & 1.10 & 6.20 & 3.80 & 3.75 & 1.60 & 0.43 \\
\hline 1-Methylnaphthalene & 15 & 0 & $<0.064$ & $<0.064$ & $<0.064$ & - & - & - \\
\hline 2-Methylnaphthalene & 15 & 4 & $<0.049$ & 0.11 & $<0.049$ & 0.06 & 0.02 & 0.34 \\
\hline
\end{tabular}

Tables $3 A$ through $3 F$ detail summary statistics for individual and total PAH concentrations. Descriptive statistics for datasets with censored values (values reported as less than the laboratory's limit of detection) were calculated by use of the nonparametric Kaplan-Meier method (Helsel, 2005). Total PAHs are the sum of individual, uncensored PAH compounds for each analyzed sample. Concentrations of PAH compounds for each sampled precipitation event are detailed in appendix tables 1-1 through 1-7. 
Table 3A. Summary statistics of polycyclic aromatic hydrocarbons for parking lots that have and have not been sealed-Continued.

$[<$, less than; - , not determined; $\mu \mathrm{g} / \mathrm{L}$, micrograms per liter; chemical nomenclature is that of the Wisconsin State Laboratory of Hygiene]

\begin{tabular}{|c|c|c|c|c|c|c|c|c|}
\hline $\begin{array}{l}\text { Polycyclic aromatic } \\
\text { hydrocarbon }\end{array}$ & $\begin{array}{c}\text { Number of } \\
\text { observations }\end{array}$ & $\begin{array}{c}\text { Number } \\
\text { of } \\
\text { detections }\end{array}$ & $\begin{array}{c}\text { Minimum } \\
(\mu \mathrm{g} / \mathrm{L})\end{array}$ & $\begin{array}{l}\text { Maximum } \\
(\mu \mathrm{g} / \mathrm{L})\end{array}$ & $\begin{array}{l}\text { Median } \\
\text { ( } \mu \mathrm{g} / \mathrm{L})\end{array}$ & $\begin{array}{l}\text { Mean } \\
(\mu \mathrm{g} / \mathrm{L})\end{array}$ & $\begin{array}{l}\text { Standard } \\
\text { deviation }\end{array}$ & $\begin{array}{c}\text { Coefficient } \\
\text { of } \\
\text { variation }\end{array}$ \\
\hline \multicolumn{9}{|c|}{ Parking lots_-Not sealed } \\
\hline Acenaphthene & 27 & 2 & $<0.064$ & 0.30 & $<0.064$ & - & - & - \\
\hline Acenaphthylene & 27 & 0 & $<0.11$ & $<0.11$ & $<0.11$ & - & - & - \\
\hline Benzo (A) Anthracene & 27 & 16 & $<0.093$ & 3.60 & 0.17 & 0.36 & 0.69 & 1.91 \\
\hline Benzo (A) Pyrene & 27 & 22 & $<0.16$ & 5.00 & 0.35 & 0.62 & 0.97 & 1.55 \\
\hline Benzo (B) Fluoranthene & 27 & 25 & $<0.13$ & 6.10 & 0.54 & 0.93 & 1.22 & 1.31 \\
\hline $\begin{array}{c}\text { Dibenzo (A, H) } \\
\text { Anthracene }\end{array}$ & 27 & 1 & $<0.034$ & 0.10 & $<0.034$ & - & - & - \\
\hline Fluoranthene & 27 & 26 & $<0.11$ & 16.00 & 1.05 & 1.94 & 3.17 & 1.64 \\
\hline Fluorene & 27 & 1 & $<0.52$ & 0.65 & $<0.52$ & - & - & - \\
\hline $\begin{array}{l}\text { Indeno }(1.2 .3-\mathrm{C}, \mathrm{D}) \\
\text { Pyrene }\end{array}$ & 27 & 26 & $<0.093$ & 4.00 & 0.43 & 0.70 & 0.83 & 1.18 \\
\hline 1-Methylnaphthalene & 27 & 0 & $<0.064$ & $<0.064$ & $<0.064$ & - & - & - \\
\hline 2-Methylnaphthalene & 27 & 0 & $<0.049$ & $<0.049$ & $<0.049$ & - & - & - \\
\hline
\end{tabular}


Table 3B. Summary statistics of polycyclic aromatic hydrocarbons for residential feeder street.

$[<$, less than; - , not determined; $\mu \mathrm{g} / \mathrm{L}$, micrograms per liter; chemical nomenclature is that of the Wisconsin State Laboratory of Hygiene $]$

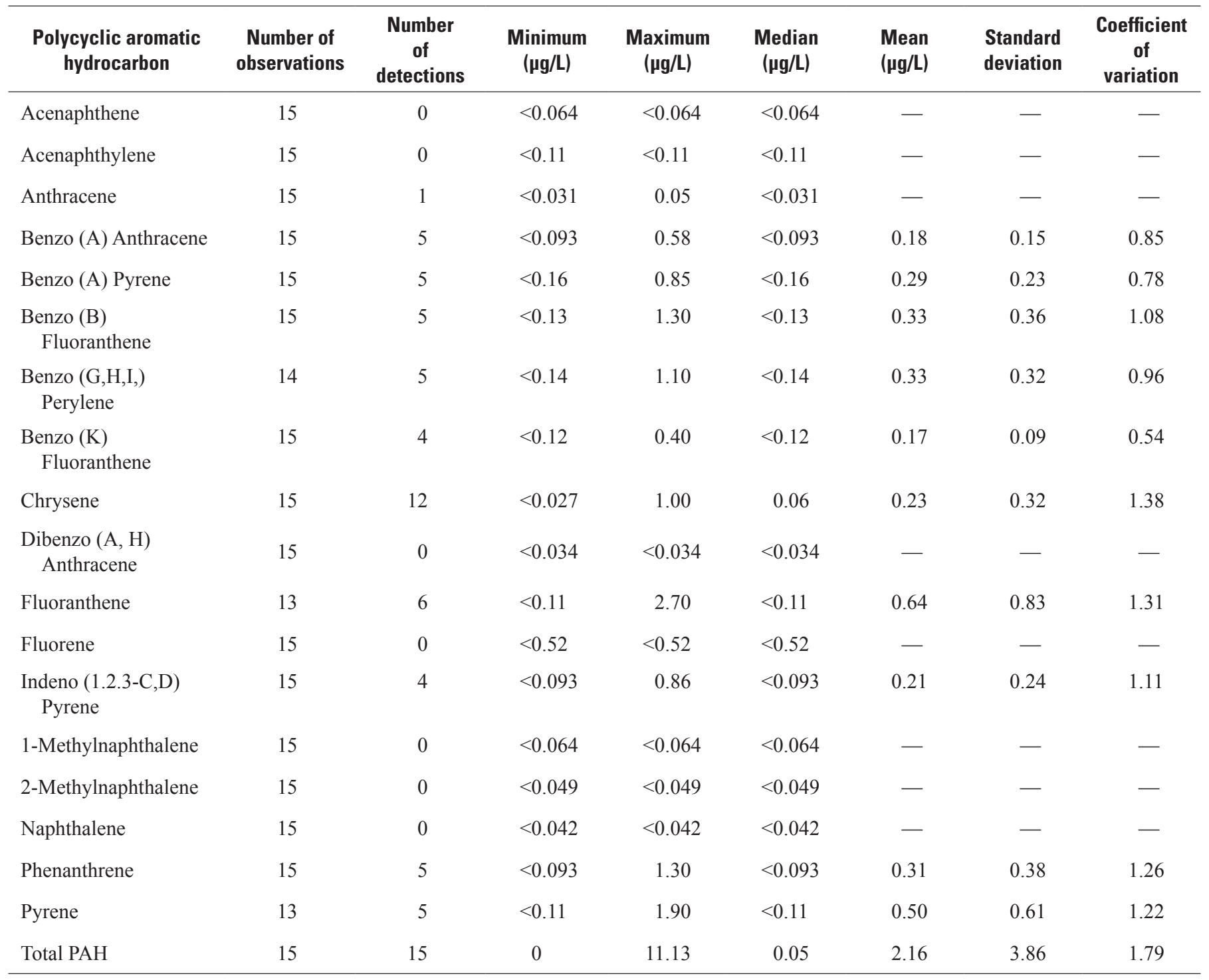


Table 3C. Summary statistics of polycyclic aromatic hydrocarbons for collector street.

$[<$, less than; - , not determined; $\mu \mathrm{g} / \mathrm{L}$, micrograms per liter; chemical nomenclature is that of the Wisconsin State Laboratory of Hygiene]

\begin{tabular}{|c|c|c|c|c|c|c|c|c|}
\hline $\begin{array}{c}\text { Polycyclic aromatic } \\
\text { hydrocarbon }\end{array}$ & $\begin{array}{c}\text { Number of } \\
\text { observations }\end{array}$ & $\begin{array}{c}\text { Number } \\
\text { of } \\
\text { detections }\end{array}$ & $\begin{array}{l}\text { Minimum } \\
(\mu \mathrm{g} / \mathrm{L})\end{array}$ & $\begin{array}{l}\text { Maximum } \\
(\mu \mathrm{g} / \mathrm{L})\end{array}$ & $\begin{array}{c}\text { Median } \\
(\mu \mathrm{g} / \mathrm{L})\end{array}$ & $\begin{array}{l}\text { Mean } \\
(\mu \mathrm{g} / \mathrm{L})\end{array}$ & $\begin{array}{l}\text { Standard } \\
\text { deviation }\end{array}$ & $\begin{array}{c}\text { Coefficient } \\
\text { of } \\
\text { variation }\end{array}$ \\
\hline Acenaphthylene & 17 & 0 & $<0.11$ & $<0.11$ & $<0.11$ & - & - & - \\
\hline Anthracene & 17 & 3 & $<0.031$ & 0.42 & $<0.031$ & - & - & - \\
\hline Benzo (A) Pyrene & 17 & 11 & $<0.16$ & 2.90 & 0.29 & 0.62 & 0.90 & 1.46 \\
\hline Benzo (B) Fluoranthene & 17 & 12 & $<0.13$ & 4.50 & 0.42 & 0.80 & 1.23 & 1.54 \\
\hline Benzo $(\mathrm{G}, \mathrm{H}, \mathrm{I}$,$) Perylene$ & 17 & 12 & $<0.14$ & 3.60 & 0.36 & 0.66 & 0.95 & 1.44 \\
\hline Fluoranthene & 17 & 16 & $<0.11$ & 9.60 & 0.93 & 1.72 & 2.80 & 1.63 \\
\hline Fluorene & 17 & 0 & $<0.52$ & $<0.52$ & $<0.52$ & - & - & - \\
\hline $\begin{array}{l}\text { Indeno }(1.2 .3-C, D) \\
\quad \text { Pyrene }\end{array}$ & 17 & 13 & $<0.093$ & 2.90 & 0.31 & 0.59 & 0.87 & 1.47 \\
\hline 1-Methylnaphthalene & 17 & 0 & $<0.064$ & $<0.064$ & $<0.064$ & - & - & - \\
\hline 2-Methylnaphthalene & 17 & 2 & $<0.049$ & 0.12 & $<0.049$ & - & - & - \\
\hline Naphthalene & 17 & 1 & $<0.042$ & 0.06 & $<0.042$ & - & - & - \\
\hline
\end{tabular}


Table 3D. Summary statistics of polycyclic aromatic hydrocarbons for arterial street.

$[<$, less than; - , not determined; $\mu \mathrm{g} / \mathrm{L}$, micrograms per liter; chemical nomenclature is that of the Wisconsin State Laboratory of Hygiene $]$

\begin{tabular}{|c|c|c|c|c|c|c|c|c|}
\hline $\begin{array}{l}\text { Polycyclic aromatic } \\
\text { hydrocarbon }\end{array}$ & $\begin{array}{c}\text { Number of } \\
\text { observations }\end{array}$ & $\begin{array}{l}\text { Number of } \\
\text { detections }\end{array}$ & $\underset{(\mu \mathrm{g} / \mathrm{L})}{\operatorname{Minimum}}$ & $\begin{array}{l}\text { Maximum } \\
(\mu \mathrm{g} / \mathrm{L})\end{array}$ & $\begin{array}{l}\text { Median } \\
(\mu \mathrm{g} / \mathrm{L})\end{array}$ & $\begin{array}{l}\text { Mean } \\
(\mu \mathrm{g} / \mathrm{L})\end{array}$ & $\begin{array}{l}\text { Standard } \\
\text { deviation }\end{array}$ & $\begin{array}{c}\text { Coefficient } \\
\text { of } \\
\text { variation }\end{array}$ \\
\hline Acenaphthene & 11 & 2 & $<0.064$ & 0.16 & $<0.064$ & - & - & - \\
\hline Acenaphthylene & 11 & 0 & $<0.11$ & $<0.11$ & $<0.11$ & - & - & - \\
\hline Anthracene & 11 & 7 & $<0.031$ & 0.56 & 0.05 & 0.15 & 0.19 & 1.27 \\
\hline Benzo (A) Anthracene & 11 & 9 & $<0.093$ & 4.00 & 0.25 & 0.94 & 1.35 & 1.43 \\
\hline Benzo (A) Pyrene & 10 & 10 & 0.17 & 6.80 & 0.52 & 1.80 & 2.34 & 1.30 \\
\hline Benzo (B) Fluoranthene & 11 & 11 & 0.24 & 12.00 & 0.67 & 2.64 & 3.82 & 1.45 \\
\hline Benzo $(\mathrm{G}, \mathrm{H}, \mathrm{I}$,$) Perylene$ & 11 & 11 & 0.27 & 7.70 & 0.56 & 2.00 & 2.59 & 1.30 \\
\hline Benzo (K) Fluoranthene & 11 & 10 & $<0.12$ & 4.80 & 0.30 & 1.15 & 1.59 & 1.39 \\
\hline Chrysene & 11 & 11 & 0.20 & 9.10 & 0.54 & 2.10 & 2.97 & 1.42 \\
\hline $\begin{array}{l}\text { Dibenzo }(\mathrm{A}, \mathrm{H}) \\
\text { Anthracene }\end{array}$ & 11 & 0 & $<0.06$ & $<0.06$ & $<0.06$ & - & - & - \\
\hline Fluoranthene & 11 & 11 & 0.49 & 22.00 & 1.20 & 4.83 & 7.07 & 1.47 \\
\hline Fluorene & 11 & 0 & $<0.52$ & $<0.52$ & $<0.52$ & - & - & - \\
\hline $\begin{array}{l}\text { Indeno }(1.2 .3-\mathrm{C}, \mathrm{D}) \\
\text { Pyrene }\end{array}$ & 11 & 11 & 0.23 & 7.30 & 0.51 & 1.84 & 2.46 & 1.34 \\
\hline 1-Methylnaphthalene & 11 & 0 & $<0.064$ & $<0.064$ & $<0.064$ & - & - & - \\
\hline 2-Methylnaphthalene & 11 & 0 & $<0.049$ & $<0.049$ & $<0.049$ & - & - & - \\
\hline Naphthalene & 11 & 2 & $<0.042$ & 0.05 & $<0.042$ & - & - & - \\
\hline Phenanthrene & 11 & 11 & 0.12 & 8.50 & 0.41 & 1.74 & 2.72 & 1.56 \\
\hline Pyrene & 11 & 11 & 0.33 & 16.00 & 0.87 & 3.51 & 5.17 & 1.48 \\
\hline Total PAH & 11 & 11 & 2.05 & 98.96 & 5.72 & 22.52 & 32.27 & 1.43 \\
\hline
\end{tabular}


Table 3E. Summary statistics of polycyclic aromatic hydrocarbons for commercial roof.

$[<$, less than; - , not determined; $\mu \mathrm{g} / \mathrm{L}$, micrograms per liter; chemical nomenclature is that of the Wisconsin State Laboratory of Hygiene]

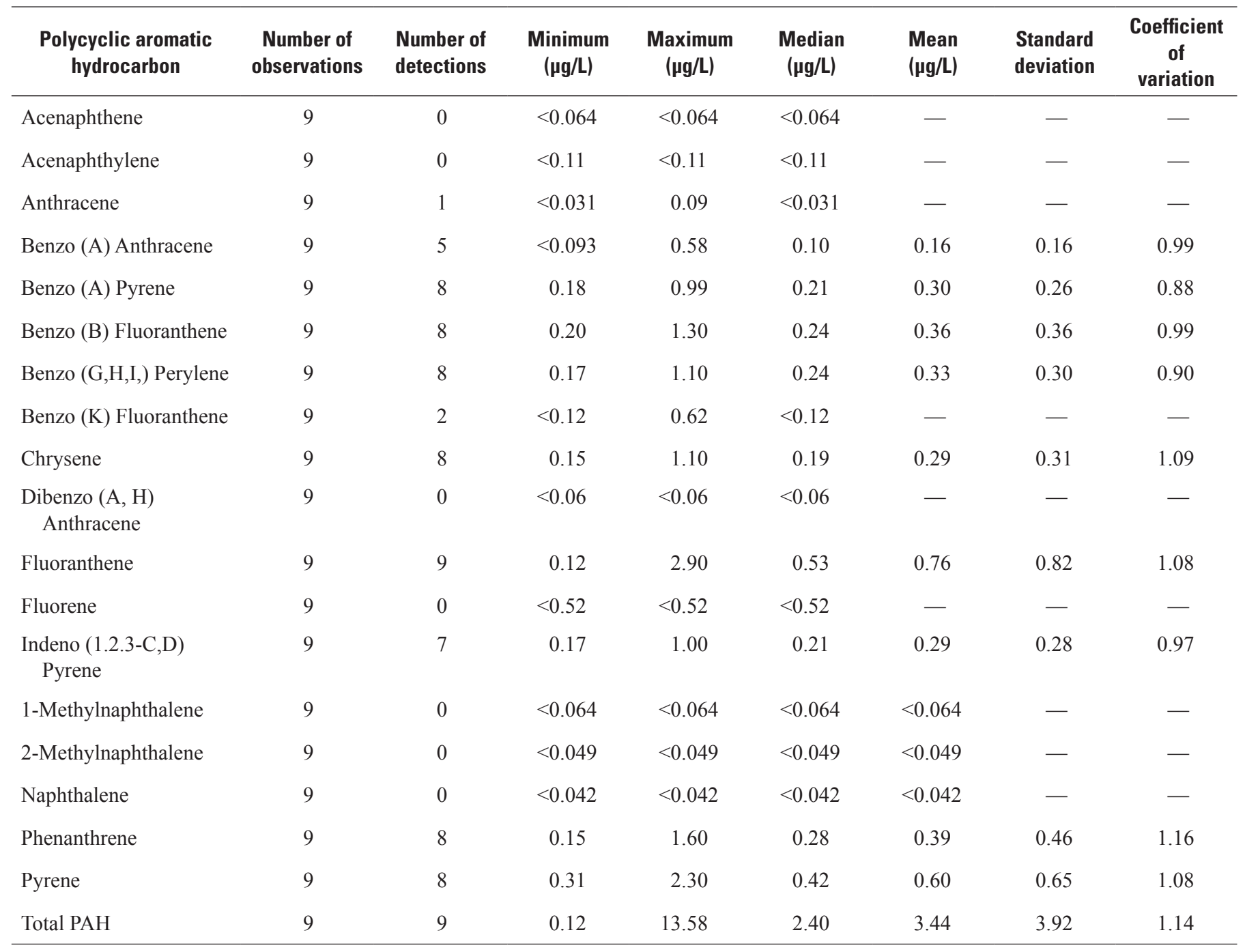


Table 3F. Summary statistics of polycyclic aromatic hydrocarbons for the mixed-use area (strip mall).

$[<$, less than; - , not determined; $\mu \mathrm{g} / \mathrm{L}$, micrograms per liter; chemical nomenclature is that of the Wisconsin State Laboratory of Hygiene $]$

\begin{tabular}{|c|c|c|c|c|c|c|c|c|}
\hline $\begin{array}{l}\text { Polycyclic aromatic } \\
\text { hydrocarbon }\end{array}$ & $\begin{array}{c}\text { Number of } \\
\text { observations }\end{array}$ & $\begin{array}{l}\text { Number of } \\
\text { detections }\end{array}$ & $\begin{array}{l}\text { Minimum } \\
(\mu \mathrm{g} / \mathrm{L})\end{array}$ & $\begin{array}{l}\text { Maximum } \\
(\mu \mathrm{g} / \mathrm{L})\end{array}$ & $\begin{array}{l}\text { Median } \\
\text { ( } \mu \mathrm{g} / \mathrm{L})\end{array}$ & $\begin{array}{l}\text { Mean } \\
(\mu \mathrm{g} / \mathrm{L})\end{array}$ & $\begin{array}{l}\text { Standard } \\
\text { deviation }\end{array}$ & $\begin{array}{c}\text { Coefficient } \\
\text { of } \\
\text { variation }\end{array}$ \\
\hline Acenaphthylene & 19 & 0 & $<0.11$ & $<0.11$ & $<0.11$ & - & - & - \\
\hline Anthracene & 19 & 0 & $<0.031$ & $<0.031$ & $<0.031$ & - & - & - \\
\hline Benzo (A) Pyrene & 19 & 15 & $<0.16$ & 1.20 & 0.32 & 0.46 & 0.33 & 0.72 \\
\hline Benzo (B) Fluoranthene & 19 & 18 & $<0.13$ & 1.70 & 0.60 & 0.74 & 0.53 & 0.72 \\
\hline Benzo $(\mathrm{G}, \mathrm{H}, \mathrm{I}$,$) Perylene$ & 19 & 17 & $<0.14$ & 1.70 & 0.56 & 0.69 & 0.48 & 0.70 \\
\hline Fluoranthene & 19 & 18 & $<0.11$ & 3.70 & 1.20 & 1.42 & 1.12 & 0.79 \\
\hline Fluorene & 19 & 0 & $<0.52$ & $<0.52$ & $<0.52$ & - & - & - \\
\hline $\begin{array}{l}\text { Indeno }(1.2 .3-\mathrm{C}, \mathrm{D}) \\
\quad \text { Pyrene }\end{array}$ & 19 & 18 & $<0.095$ & 1.50 & 0.55 & 0.65 & 0.45 & 0.69 \\
\hline 1-Methylnaphthalene & 19 & 0 & $<0.064$ & $<0.064$ & $<0.064$ & - & - & - \\
\hline 2-Methylnaphthalene & 19 & 0 & $<0.049$ & $<0.049$ & $<0.049$ & - & - & - \\
\hline Naphthalene & 19 & 0 & $<0.042$ & $<0.042$ & $<0.042$ & - & - & - \\
\hline
\end{tabular}




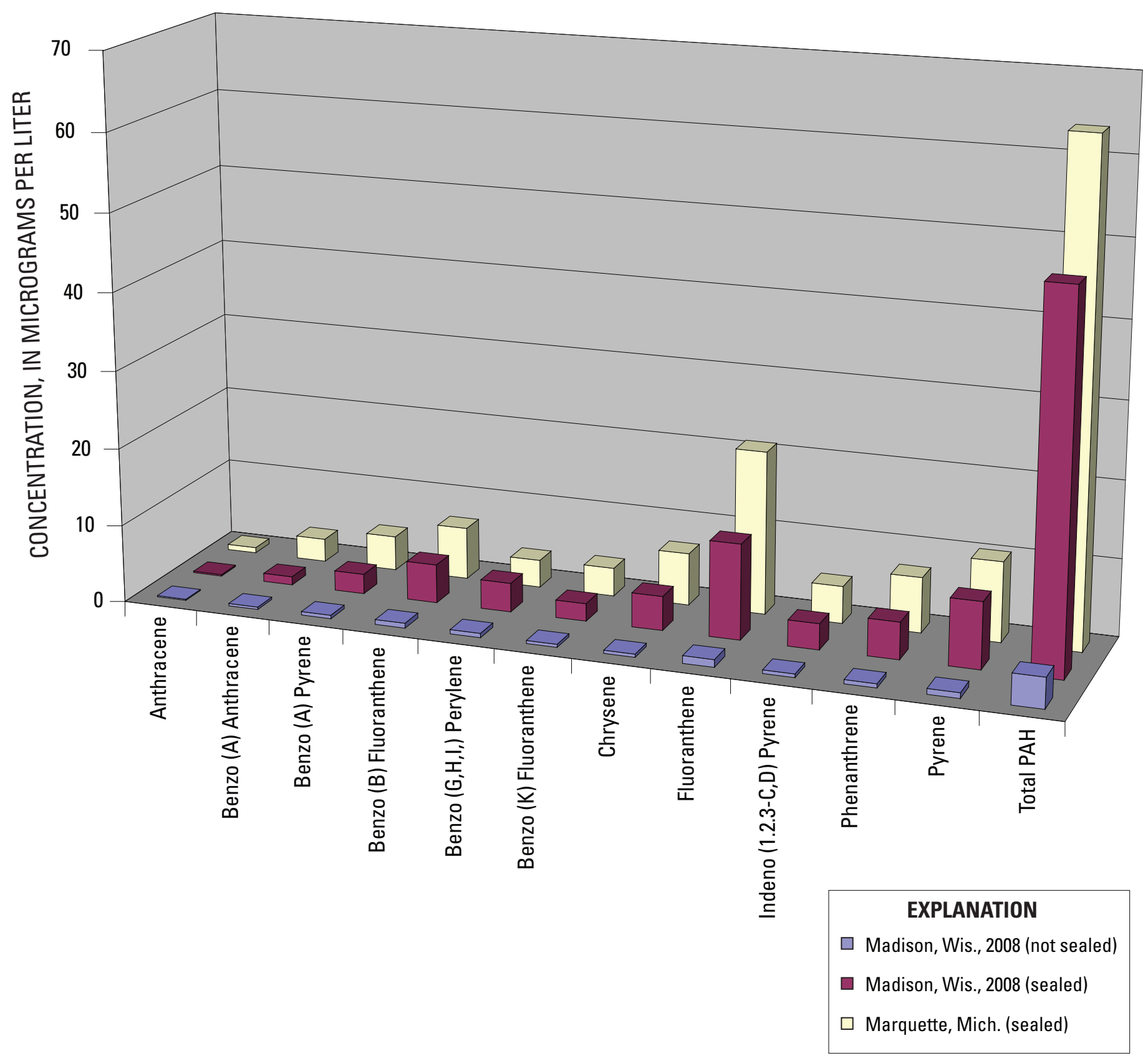

Figure 10A. Geometric mean concentrations of polycyclic aromatic hydrocarbons from parking lots in Madison, Wis., and Marquette, Mich.

Figures $10 \mathrm{~A}$ through $10 \mathrm{~F}$ compare geometric mean concentrations of select PAH compounds from this study to those from similar studies done in Marquette, Mich., and Madison, Wis. (Steuer and others, 1997) in 1993 and 1994, respectively. Source areas monitored as part of the Madison, Wis., study in 1994 included only feeder, collector, and arterial streets. In contrast to this study, Waschbusch and Steuer collected urban runoff with source-area-specific water-quality samplers rather than autosamplers placed at the basin outfall. Descriptions of each source-area sampler are detailed in Waschbusch (1999).
In general, the pattern of individual PAH compound concentrations were similar between studies for all source areas monitored. PAH concentrations for feeder-street runoff were similar in both Madison studies but tended to be lower in Marquette, Mich. (fig. 10C). Conversely, collector-street runoff had similar PAH concentrations for both Madison studies, but concentrations were higher in the Marquette runoff (fig. 10D). PAH concentrations for arterial street runoff were similar for all three studies (fig. 10E). 


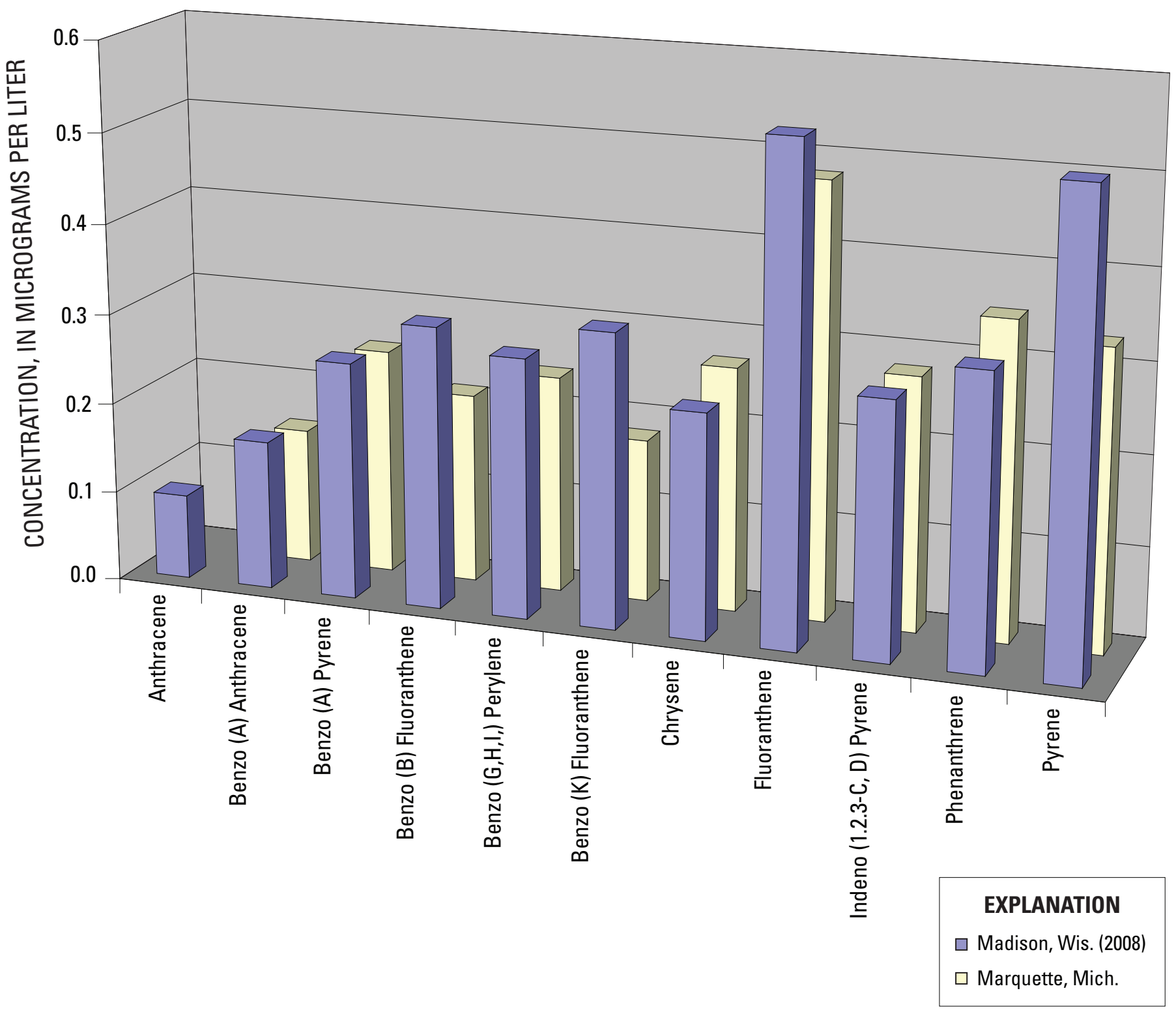

Figure 10B. Geometric mean concentrations of polycyclic aromatic hydrocarbons from commercial roofs in Madison, Wis., and Marquette, Mich.

Geometric mean concentrations for most individual PAH compounds were significantly greater for parking lots that were sealed than for those that were not sealed. Runoff from both of the coal-tar sealed parking lots that were monitored in Marquette, Mich., and Madison, Wis., had similar geometric mean concentrations despite the distance between locations and length of time between studies. These results are consistent with a similar study that examined PAH concentrations from coal-tar-sealed parking lots in Austin, Tex. (Van Metre and others, 2005). 


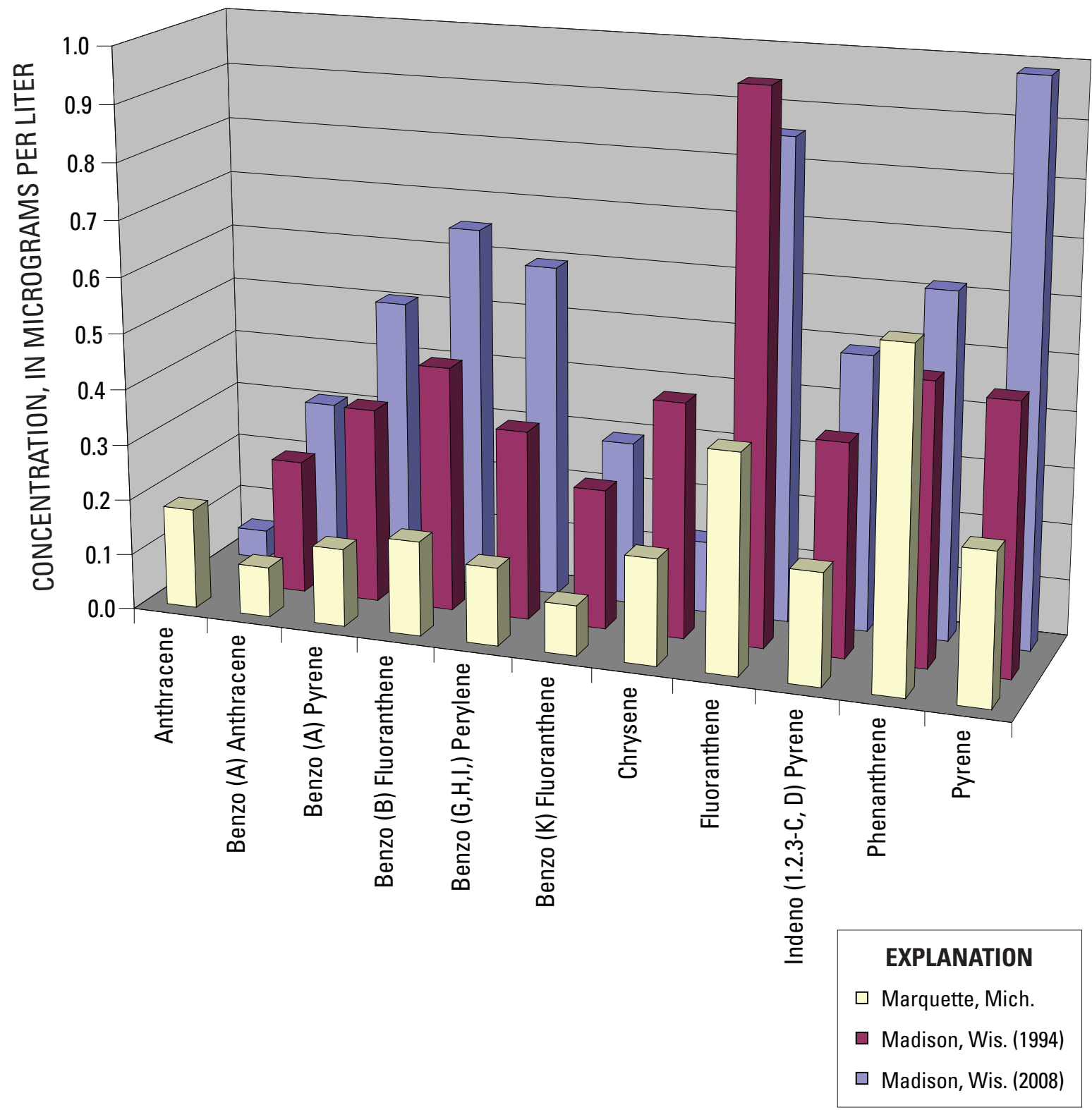

Figure 10C. Geometric mean concentrations of polycyclic aromatic hydrocarbons from feeder streets in Madison, Wis., and Marquette, Mich. 


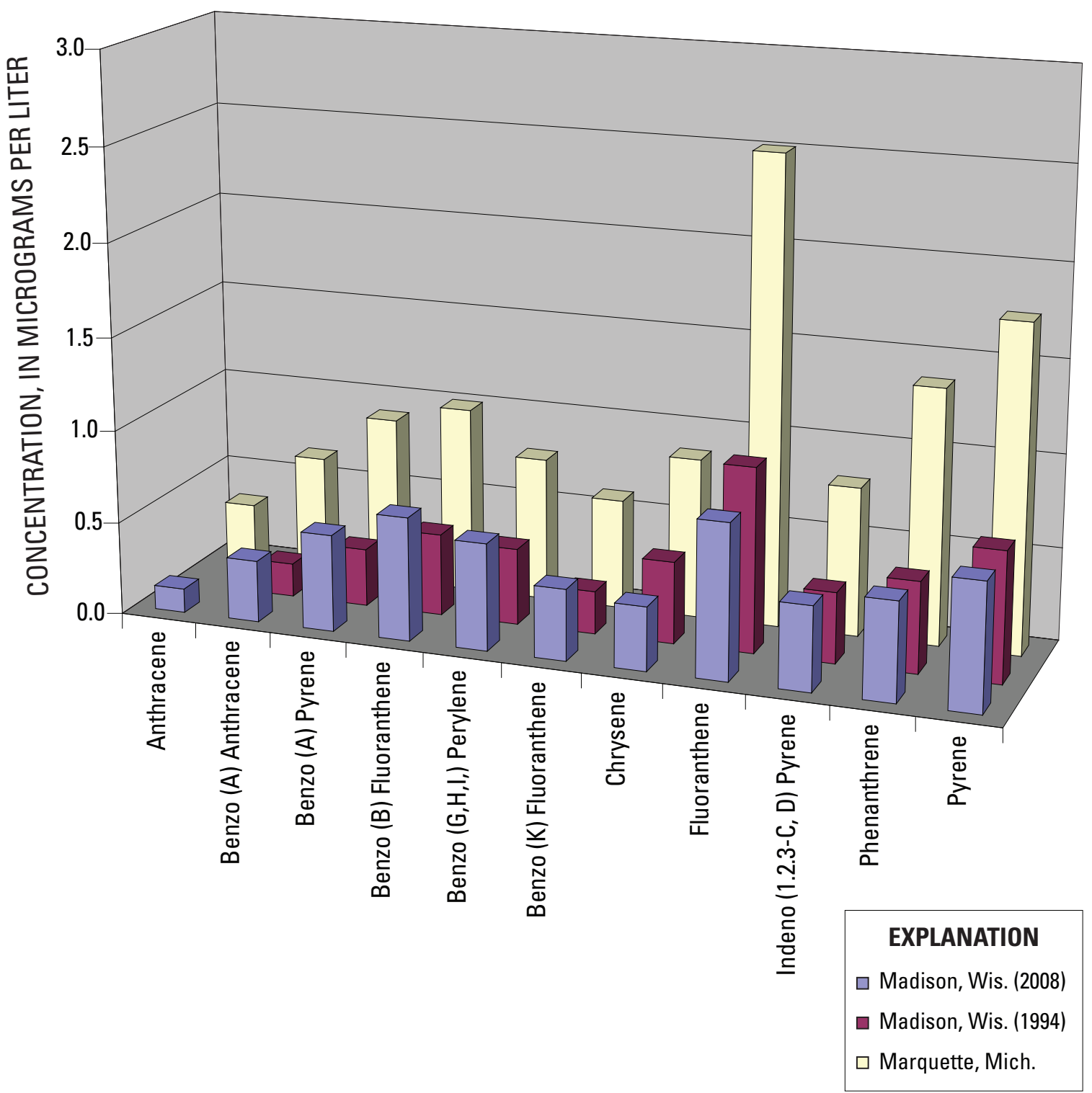

Figure 10D. Geometric mean concentrations of polycyclic aromatic hydrocarbons from collector streets in Madison, Wis., and Marquette, Mich. 


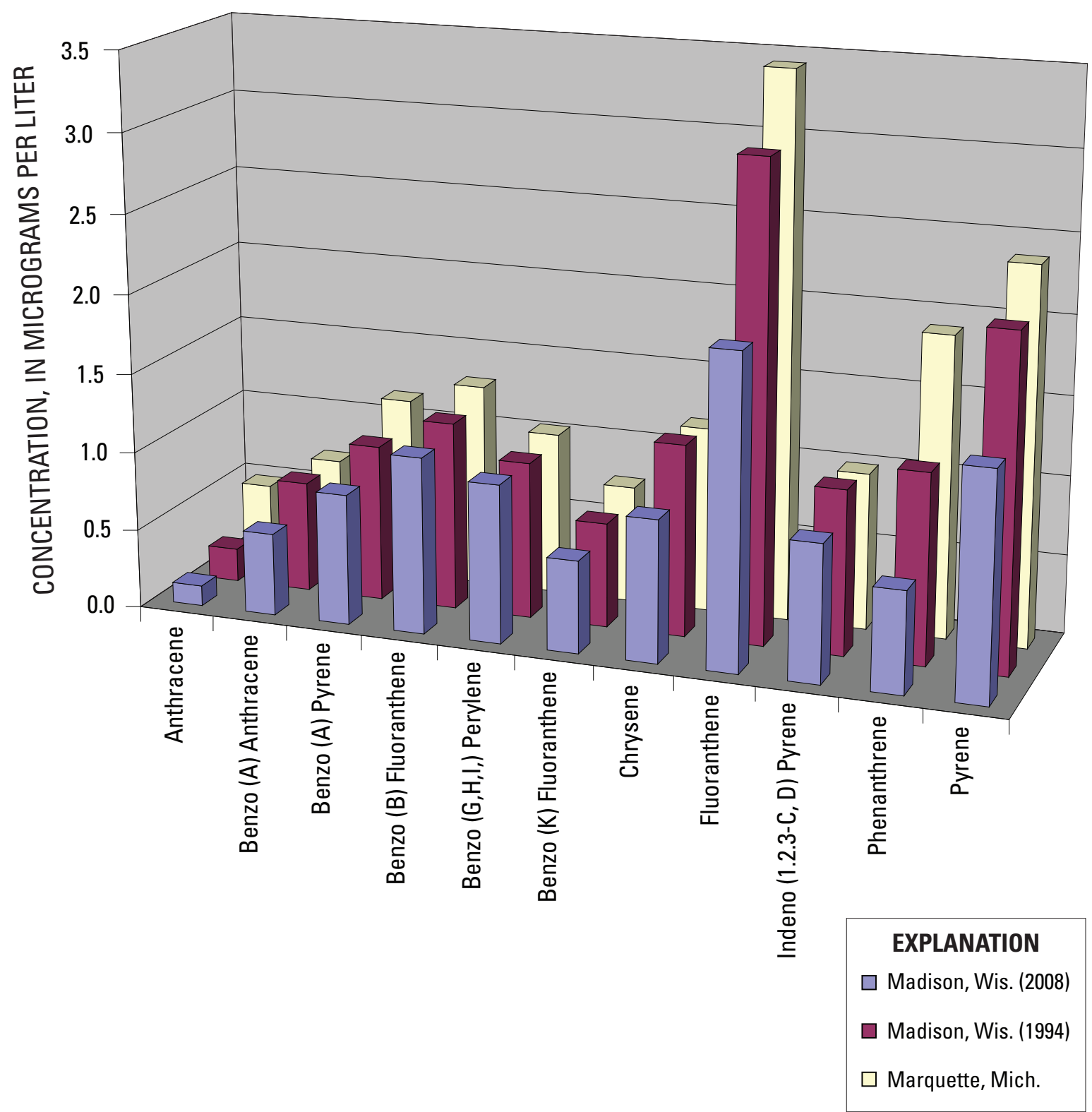

Figure 10E. Geometric mean concentrations of polycyclic aromatic hydrocarbons from arterial streets in Madison, Wis., and Marquette, Mich. 


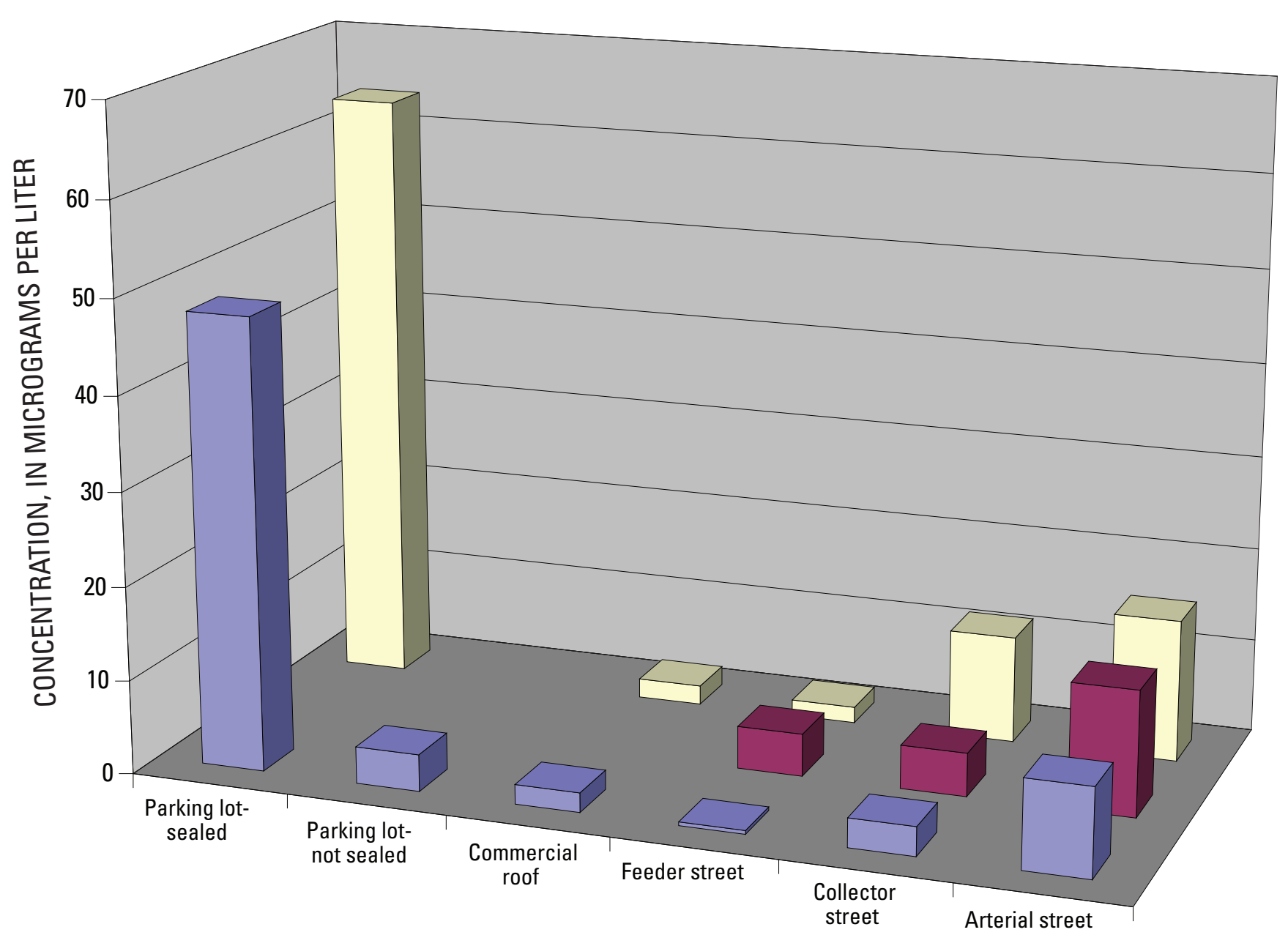

\begin{tabular}{|c|}
\hline EXPLANATION \\
$\square$ Madison, Wis. (2008) \\
$\square$ Madison, Wis. (1994) \\
$\square$ Marquette, Mich \\
\hline
\end{tabular}

Figure 10F. Geometric mean concentrations of total polycyclic aromatic hydrocarbons from source areas monitored in Madison, Wis., and Marquette, Mich. 


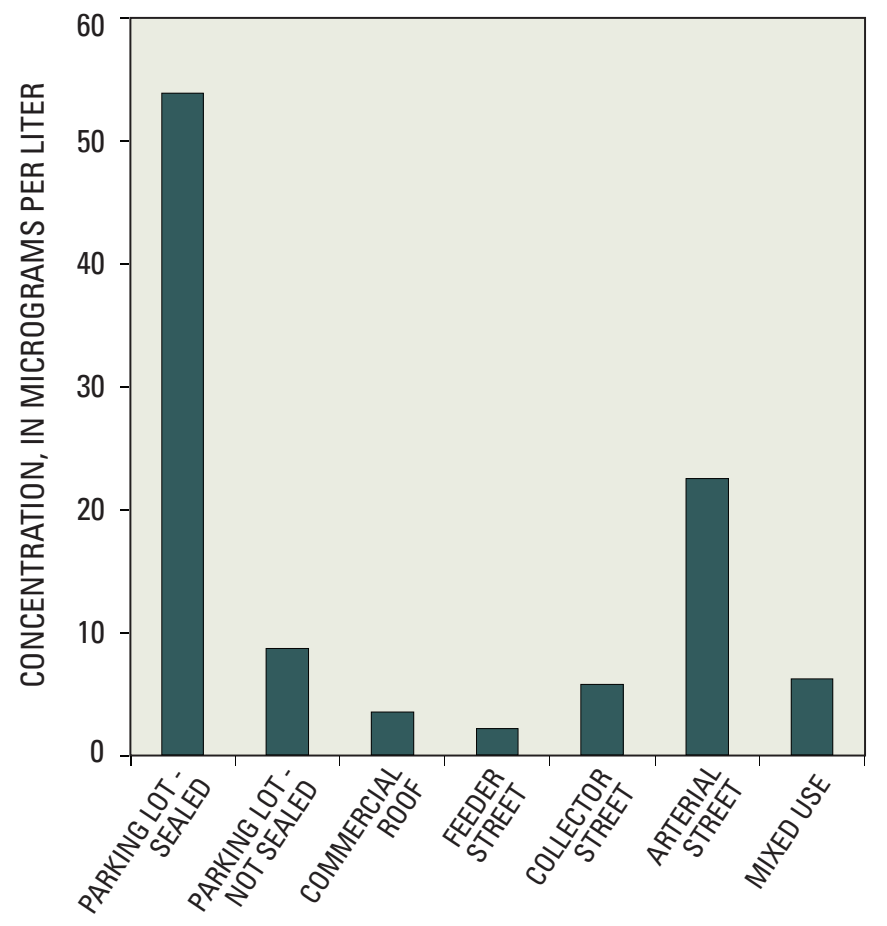

Figure 11. Mean concentration of total polycyclic aromatic hydrocarbons from source areas monitored in Madison, Wis. (2008).

Figure 11 shows the mean total PAH concentrations for the Madison, Wis., 2008 study. Runoff from the sealed parking lot had the largest concentration, followed by runoff from the unsealed parking lots, the arterial street, the mixed-use area (strip mall), the collector street, the commercial roof, and finally, the feeder street. Similar to the Madison 2008 study, geometric mean total PAH concentrations in the Marquette study were greatest for sealed parking lots followed by those for arterial, collector, and feeder streets (fig. 10F). Runoff from commercial roofs had the lowest total PAH geometric mean concentrations (fig. 10F).

\section{References}

Helsel, D.R., 2005, Nondetects and data analysis - Statistics for censored environmental data: Hoboken, N.J., John Wiley and Sons, $250 \mathrm{p}$.

Hoffman, E.J., 1985, Urban runoff pollutant inputs to Narragansett Bay - Comparison to point sources, in Proceedings from the Conference on Perspectives on Nonpoint Source Pollution: U.S. Environmental Protection Agency, EPA 440/5-85-001, p. 159-164.
Menzie, C.A., Hoeppner, S.S., Cura, J.J., Freshman, J.S., and LaFrey, E.N., 2002, Urban and suburban storm water runoff as a source of polycyclic aromatic hydrocarbons (PAHs) to Massachusetts estuarine and coastal environments: Estuaries, v. 25 , no. 2 , p. 165-176.

Stein, E.D., Tiefenthaler, L.L., and Schiff, K., 2006, Watershed-based sources of polycyclic aromatic hydrocarbons in urban storm water: Environmental Toxicology and Chemistry, v. 25, no. 2, p. 373-385.

Steuer, J.J., Selbig, W.R., and Hornewer, N.J., 1996, Contaminant concentration in stormwater from eight Lake Superior basin cities, 1993-94, U.S. Geological Survey Open-File Report 96-122, 16 p.

Steuer, J.J., Selbig, W.R., Hornewer, N.J., and Prey, Jeffrey, 1997, Sources of contamination in an urban basin in Marquette, Michigan and an analysis of concentrations, loads, and data quality: U.S. Geological Survey Water-Resources Investigations Report 97-4242, 25 p.

Van Metre, P.C.; Mahler, B.J.; Scoggins, Mateo; and Hamilton, P.A., 2005, Parking lot sealcoat-A major source of polycyclic aromatic hydrocarbons (PAHs) in urban and suburban environments: U.S. Geological Survey Fact Sheet 2005-3147, 4 p.

Waschbusch, R.J., Selbig, W.R., and Bannerman, R.T., 1999, Sources of phosphorus in stormwater and street dirt from two urban residential basins in Madison, Wisconsin, 199495, U.S. Geological Survey Water-Resources Investigations Report 99-4021, 47 p.

Prepared by the Wisconsin Water Science Center:

U.S. Geological Survey

Wisconsin Water Science Center

8505 Research Way

Middleton, WI 53562

tel: (608) 828-9901

fax: (608) 821-3817

This publication is available online at URL http://pubs.usgs.gov/ofr/2009/1077

Information regarding the Wisconsin Water Science Center is available at URL: http://wi.water.usgs.gov

Information regarding the Wisconsin Water Science Center's Lakes Team is available at URL: http://wi.water.usgs.gov/lakes 


\section{Appendix Tables 1-1 - 1-7}

1-1. Concentrations of PAH compounds and total PAH summation for parking lots

$$
1 \text { and } 2 \text {........ }
$$

1-2. Concentrations of PAH compounds and total PAH summation for parking lot $3 . . . . . . . . . . . . . . .32$

1-3. Concentrations of PAH compounds and total PAH summation for feeder street. ................35

1-4. Concentrations of PAH compounds and total PAH summation for collector street. ............37

1-5. Concentrations of PAH compounds and total PAH summation for arterial street...............40

1-6. Concentrations of PAH compounds and total PAH summation for commercial roof...........42

1-7. Concentrations of PAH compounds and total PAH summation for a mixed-

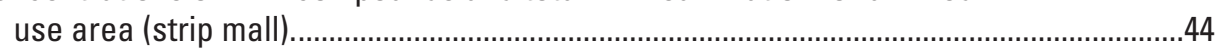


Table 1-1. Concentrations of PAH compounds and total PAH summation for parking lots 1 and 2.

$[<$, less than; all values expressed as micrograms per liter; chemical nomenclature is that of the Wisconsin State Laboratory of Hygiene]

\begin{tabular}{|c|c|c|c|c|c|c|c|c|c|c|c|}
\hline Sample ID & Date & $\begin{array}{l}\text { Acenaph- } \\
\text { thene }\end{array}$ & $\begin{array}{l}\text { Acenaph- } \\
\text { thylene }\end{array}$ & Anthracene & $\begin{array}{c}\text { Benzo (A) } \\
\text { Anthracene }\end{array}$ & $\begin{array}{c}\text { Benzo (A) } \\
\text { Pyrene }\end{array}$ & $\begin{array}{c}\text { Benzo (B) } \\
\text { Fluoran- } \\
\text { thene }\end{array}$ & $\begin{array}{c}\text { Benzo } \\
(\mathbf{G}, \mathbf{H}, \mathbf{I},) \\
\text { Perylene }\end{array}$ & $\begin{array}{c}\text { Benzo (K) } \\
\text { Fluoran- } \\
\text { thene }\end{array}$ & Chrysene & $\begin{array}{c}\text { Dibenzo (A, } \\
\text { H) Anthra- } \\
\text { cene }\end{array}$ \\
\hline $\begin{array}{l}\text { PARKING } \\
\text { LOT } 1 \text { - } 1\end{array}$ & 09/10/2006 & $<.064$ & $<.11$ & $<.031$ & $<.093$ & $<.16$ & $<.13$ & $<.14$ & $<.12$ & 0.04 & $<.034$ \\
\hline $\begin{array}{l}\text { PARKING } \\
\text { LOT } 1 \text { - } 2\end{array}$ & $10 / 10 / 2006$ & $<.064$ & $<.11$ & $<.031$ & $<.093$ & $<.16$ & 0.19 & 0.21 & $<.12$ & 0.14 & $<.034$ \\
\hline $\begin{array}{l}\text { PARKING } \\
\text { LOT } 1 \text { - } 3\end{array}$ & $10 / 16 / 2006$ & 0.20 & $<.11$ & $<.031$ & $<.093$ & 0.22 & 0.29 & 0.32 & $<.12$ & 0.21 & $<.034$ \\
\hline $\begin{array}{l}\text { PARKING } \\
\text { LOT } 1 \text { - } 4\end{array}$ & $10 / 21 / 2006$ & $<.064$ & $<.11$ & $<.031$ & $<.093$ & 0.26 & 0.36 & 0.38 & 0.16 & 0.28 & $<.034$ \\
\hline $\begin{array}{l}\text { PARKING } \\
\text { LOT } 1 \text { - } 5\end{array}$ & $04 / 02 / 2007$ & $<.064$ & $<.11$ & 0.19 & 0.75 & 1.20 & 1.80 & 1.60 & 0.81 & 1.50 & $<0.15$ \\
\hline $\begin{array}{l}\text { PARKING } \\
\text { LOT } 1 \text { - } 6\end{array}$ & $04 / 24 / 2007$ & $<.064$ & $<.11$ & $<.031$ & 0.22 & 0.40 & 0.67 & 0.59 & 0.30 & 0.55 & $<0.064$ \\
\hline $\begin{array}{l}\text { PARKING } \\
\text { LOT } 1 \text { - } 7\end{array}$ & $04 / 25 / 2007$ & $<.064$ & $<.11$ & 0.05 & 0.31 & 0.57 & 0.98 & 0.85 & 0.45 & 0.79 & 0.10 \\
\hline $\begin{array}{l}\text { PARKING } \\
\text { LOT } 1 \text { - } 8\end{array}$ & $05 / 24 / 2007$ & $<.064$ & $<.11$ & $<0.040$ & 0.31 & 0.67 & 1.30 & 1.10 & 0.56 & 0.98 & $<0.088$ \\
\hline $\begin{array}{l}\text { PARKING } \\
\text { LOT } 1 \text { - } 9\end{array}$ & $06 / 18 / 2007$ & $<.064$ & $<.11$ & $<.031$ & $<.093$ & 0.26 & 0.44 & 0.43 & 0.18 & 0.31 & $<.034$ \\
\hline $\begin{array}{l}\text { PARKING } \\
\quad \text { LOT } 1 \text { - } 10\end{array}$ & $07 / 26 / 2007$ & $<.064$ & $<.11$ & $<.031$ & 0.25 & 0.37 & 1.30 & 1.10 & 0.51 & 0.87 & $<0.093$ \\
\hline $\begin{array}{l}\text { PARKING } \\
\quad \text { LOT } 1 \text { - } 11\end{array}$ & $08 / 04 / 2007$ & $<.064$ & $<.11$ & $<.031$ & $<.093$ & $<.16$ & 0.14 & 0.16 & $<.12$ & 0.10 & $<.034$ \\
\hline $\begin{array}{l}\text { PARKING } \\
\quad \text { LOT } 1 \text { - } 12\end{array}$ & 08/06/2007 & $<.064$ & $<.11$ & $<.031$ & $<.093$ & $<.16$ & $<.13$ & 0.14 & $<.12$ & 0.08 & $<.034$ \\
\hline $\begin{array}{l}\text { PARKING } \\
\quad \text { LOT } 1-13\end{array}$ & $08 / 15 / 2007$ & $<.064$ & $<.11$ & $<.031$ & $<.093$ & $<.16$ & 0.21 & 0.23 & $<.12$ & 0.13 & $<.034$ \\
\hline
\end{tabular}


Table 1-1. Concentrations of PAH compounds and total PAH summation for parking lots 1 and 2-Continued.

$[<$, less than; all values expressed as micrograms per liter; chemical nomenclature is that of the Wisconsin State Laboratory of Hygiene]

\begin{tabular}{|c|c|c|c|c|c|c|c|c|c|c|}
\hline Sample ID & Date & $\begin{array}{l}\text { Fluoran- } \\
\text { thene }\end{array}$ & Fluorene & $\begin{array}{c}\text { Indeno } \\
(1.2 .3-C, D) \\
\text { Pyrene }\end{array}$ & $\begin{array}{c}\text { 1-Methyl- } \\
\text { naphthalene }\end{array}$ & $\begin{array}{c}\text { 2-Methyl- } \\
\text { naphthalene }\end{array}$ & Naphthalene & $\begin{array}{l}\text { Phenan- } \\
\text { threne }\end{array}$ & Pyrene & Total PAH \\
\hline $\begin{array}{l}\text { PARKING } \\
\text { LOT } 1 \text { - } 1\end{array}$ & 09/10/2006 & $<.11$ & $<.52$ & $<.093$ & $<.064$ & $<.049$ & $<.042$ & $<.093$ & $<.11$ & 0.04 \\
\hline $\begin{array}{l}\text { PARKING } \\
\text { LOT } 1 \text { - } 2\end{array}$ & $10 / 10 / 2006$ & 0.27 & $<.52$ & 0.15 & $<.064$ & $<.049$ & $<.042$ & $<.093$ & 0.20 & 1.16 \\
\hline $\begin{array}{l}\text { PARKING } \\
\text { LOT } 1 \text { - } 3\end{array}$ & $10 / 16 / 2006$ & 0.42 & $<.52$ & 0.25 & $<.064$ & $<.049$ & $<.042$ & 0.21 & 0.32 & 2.44 \\
\hline $\begin{array}{l}\text { PARKING } \\
\text { LOT } 1 \text { - } 4\end{array}$ & $10 / 21 / 2006$ & 0.52 & $<.52$ & 0.28 & $<.064$ & $<.049$ & $<.042$ & 0.14 & 0.40 & 2.78 \\
\hline $\begin{array}{l}\text { PARKING } \\
\text { LOT } 1 \text { - } 5\end{array}$ & $04 / 02 / 2007$ & 3.60 & $<.52$ & 1.40 & $<.064$ & $<.049$ & $<.042$ & 1.80 & 2.70 & 17.35 \\
\hline $\begin{array}{l}\text { PARKING } \\
\text { LOT } 1 \text { - } 6\end{array}$ & $04 / 24 / 2007$ & 1.40 & $<.52$ & 0.44 & $<.064$ & $<.049$ & $<.042$ & 0.37 & 0.94 & 5.88 \\
\hline $\begin{array}{l}\text { PARKING } \\
\text { LOT } 1 \text { - } 7\end{array}$ & $04 / 25 / 2007$ & 1.90 & $<.52$ & 0.64 & $<.064$ & $<.049$ & $<.042$ & 0.71 & 1.40 & 8.75 \\
\hline $\begin{array}{l}\text { PARKING } \\
\text { LOT } 1 \text { - } 8\end{array}$ & $05 / 24 / 2007$ & 2.20 & $<.52$ & 0.93 & $<.064$ & $<.049$ & $<.042$ & 0.81 & 1.50 & 10.36 \\
\hline $\begin{array}{l}\text { PARKING } \\
\text { LOT } 1 \text { - } 9\end{array}$ & $06 / 18 / 2007$ & 0.60 & $<.52$ & 0.33 & $<.064$ & $<.049$ & $<.042$ & 0.18 & 0.42 & 3.15 \\
\hline $\begin{array}{l}\text { PARKING } \\
\text { LOT } 1 \text { - } 10\end{array}$ & $07 / 26 / 2007$ & 1.70 & $<.52$ & 0.91 & $<.064$ & $<.049$ & $<.042$ & 0.57 & 1.30 & 8.88 \\
\hline $\begin{array}{l}\text { PARKING } \\
\quad \text { LOT } 1 \text { - } 11\end{array}$ & $08 / 04 / 2007$ & 0.18 & $<.52$ & 0.15 & $<.064$ & $<.049$ & $<.042$ & $<.093$ & 0.13 & 0.86 \\
\hline $\begin{array}{l}\text { PARKING } \\
\text { LOT } 1 \text { - } 12\end{array}$ & $08 / 06 / 2007$ & 0.16 & $<.52$ & 0.12 & $<.064$ & $<.049$ & $<.042$ & $<.093$ & 0.12 & 0.62 \\
\hline $\begin{array}{l}\text { PARKING } \\
\text { LOT } 1 \text { - } 13\end{array}$ & $08 / 15 / 2007$ & 0.25 & $<.52$ & 0.18 & $<.064$ & $<.049$ & $<.042$ & $<.093$ & 0.20 & 1.20 \\
\hline
\end{tabular}


Table 1-1. Concentrations of PAH compounds and total PAH summation for parking lots 1 and 2-Continued.

$[<$, less than; all values expressed as micrograms per liter; chemical nomenclature is that of the Wisconsin State Laboratory of Hygiene $]$

\begin{tabular}{|c|c|c|c|c|c|c|c|c|c|c|c|}
\hline Sample ID & Date & $\begin{array}{l}\text { Acenaph- } \\
\text { thene }\end{array}$ & $\begin{array}{l}\text { Acenaph- } \\
\text { thylene }\end{array}$ & Anthracene & $\begin{array}{c}\text { Benzo (A) } \\
\text { Anthracene }\end{array}$ & $\begin{array}{c}\text { Benzo (A) } \\
\text { Pyrene }\end{array}$ & $\begin{array}{c}\text { Benzo (B) } \\
\text { Fluoran- } \\
\text { thene }\end{array}$ & $\begin{array}{c}\text { Benzo } \\
(\mathrm{G}, \mathrm{H}, \mathrm{I},) \\
\text { Perylene }\end{array}$ & $\begin{array}{c}\text { Benzo (K) } \\
\text { Fluoran- } \\
\text { thene }\end{array}$ & Chrysene & $\begin{array}{l}\text { Dibenzo (A, } \\
\text { H) Anthra- } \\
\text { cene }\end{array}$ \\
\hline $\begin{array}{l}\text { PARKING } \\
\quad \text { LOT } 1 \text { - } 14\end{array}$ & $08 / 18 / 2007$ & $<.064$ & $<.11$ & $<.031$ & 0.25 & 0.50 & 0.83 & 0.80 & 0.37 & 0.59 & $<0.071$ \\
\hline $\begin{array}{l}\text { PARKING } \\
\quad \text { LOT } 1 \text { - } 15\end{array}$ & $09 / 21 / 2007$ & $<.064$ & $<.11$ & $<.031$ & 0.18 & 0.36 & 0.64 & 0.67 & 0.28 & 0.46 & $<0.059$ \\
\hline $\begin{array}{l}\text { PARKING } \\
\text { LOT } 2 \text { - } 1\end{array}$ & $08 / 23 / 2006$ & 0.30 & $<.11$ & 1.30 & 3.60 & 5.00 & 6.10 & 5.00 & 2.90 & 5.70 & $<0.50$ \\
\hline $\begin{array}{l}\text { PARKING } \\
\text { LOT } 2 \text { - } 2\end{array}$ & $09 / 10 / 2006$ & $<.064$ & $<.11$ & $<.031$ & $<.093$ & 0.16 & 0.22 & 0.23 & $<.12$ & 0.17 & $<.034$ \\
\hline $\begin{array}{l}\text { PARKING } \\
\text { LOT } 2 \text { - } 3\end{array}$ & $10 / 04 / 2006$ & $<.064$ & $<.11$ & 0.05 & 0.33 & 1.00 & 1.70 & 1.30 & 0.77 & 1.50 & $<0.12$ \\
\hline $\begin{array}{l}\text { PARKING } \\
\text { LOT } 2 \text { - } 4\end{array}$ & $10 / 16 / 2006$ & $<.064$ & $<.11$ & $<.031$ & $<.093$ & 0.16 & 0.17 & 0.18 & $<.12$ & 0.12 & $<.034$ \\
\hline $\begin{array}{l}\text { PARKING } \\
\text { LOT } 2 \text { - } 5\end{array}$ & 03/10/2007 & $<.064$ & $<.11$ & $<.031$ & 0.17 & 0.45 & 0.69 & 0.60 & 0.31 & 0.57 & $<0.050$ \\
\hline $\begin{array}{l}\text { PARKING } \\
\text { LOT } 2 \text { - } 6\end{array}$ & $03 / 11 / 2007$ & $<.064$ & $<.11$ & $<.031$ & 0.16 & 0.35 & 0.53 & 0.46 & 0.24 & 0.42 & $<0.036$ \\
\hline $\begin{array}{l}\text { PARKING } \\
\text { LOT } 2 \text { - } 7\end{array}$ & $03 / 12 / 2007$ & $<.064$ & $<.11$ & $<.031$ & 0.17 & 0.34 & 0.54 & 0.46 & 0.23 & 0.43 & $<0.038$ \\
\hline $\begin{array}{l}\text { PARKING } \\
\text { LOT } 2 \text { - } 8\end{array}$ & $03 / 13 / 2007$ & $<.064$ & $<.11$ & $<.031$ & 0.24 & 0.47 & 0.81 & 0.68 & 0.33 & 0.65 & $<0.057$ \\
\hline $\begin{array}{l}\text { PARKING } \\
\text { LOT } 2 \text { - } 9\end{array}$ & $03 / 31 / 2007$ & $<.064$ & $<.11$ & 0.19 & 1.20 & 2.00 & 2.90 & 2.50 & 1.40 & 2.50 & $<0.23$ \\
\hline $\begin{array}{l}\text { PARKING } \\
\text { LOT } 2 \text { - } 10\end{array}$ & $04 / 03 / 2007$ & $<.064$ & $<.11$ & 0.07 & 0.48 & 0.82 & 1.20 & 1.00 & 0.54 & 0.98 & $<0.098$ \\
\hline $\begin{array}{l}\text { PARKING } \\
\quad \text { LOT } 2 \text { - } 11\end{array}$ & $04 / 24 / 2007$ & $<.064$ & $<.11$ & $<.031$ & $<.093$ & 0.18 & 0.41 & 0.35 & 0.17 & 0.30 & $<.034$ \\
\hline $\begin{array}{l}\text { PARKING } \\
\text { LOT } 2-12\end{array}$ & $05 / 24 / 2007$ & $<.064$ & $<.11$ & $<.031$ & 0.11 & 0.25 & 0.44 & 0.41 & 0.20 & 0.34 & $<.034$ \\
\hline
\end{tabular}


Table 1-1. Concentrations of PAH compounds and total PAH summation for parking lots 1 and 2 - Continued.

$[<$, less than; all values expressed as micrograms per liter; chemical nomenclature is that of the Wisconsin State Laboratory of Hygiene]

\begin{tabular}{|c|c|c|c|c|c|c|c|c|c|c|}
\hline Sample ID & Date & $\begin{array}{c}\text { Fluoran- } \\
\text { thene }\end{array}$ & Fluorene & $\begin{array}{c}\text { Indeno } \\
(1.2 .3-C, D) \\
\text { Pyrene } \\
\end{array}$ & $\begin{array}{c}\text { 1-Methyl- } \\
\text { naphthalene }\end{array}$ & $\begin{array}{c}\text { 2-Methyl- } \\
\text { naphthalene }\end{array}$ & Naphthalene & $\begin{array}{c}\text { Phenan- } \\
\text { threne }\end{array}$ & Pyrene & Total PAH \\
\hline $\begin{array}{l}\text { PARKING } \\
\qquad \text { LOT } 1 \text { - } 14\end{array}$ & $08 / 18 / 2007$ & 1.10 & $<.52$ & 0.65 & $<.064$ & $<.049$ & $<.042$ & 0.36 & 0.88 & 6.33 \\
\hline $\begin{array}{l}\text { PARKING } \\
\text { LOT } 1 \text { - } 15\end{array}$ & $09 / 21 / 2007$ & 0.88 & $<.52$ & 0.52 & $<.064$ & $<.049$ & $<.042$ & 0.31 & 0.68 & 4.98 \\
\hline $\begin{array}{l}\text { PARKING } \\
\text { LOT } 2 \text { - } 1\end{array}$ & $08 / 23 / 2006$ & 16.00 & 0.65 & 4.00 & $<.064$ & $<.049$ & $<.042$ & 8.70 & 12.00 & 71.25 \\
\hline $\begin{array}{l}\text { PARKING } \\
\text { LOT } 2 \text { - } 2\end{array}$ & $09 / 10 / 2006$ & 0.29 & $<.52$ & 0.18 & $<.064$ & $<.049$ & $<.042$ & $<.093$ & 0.22 & 1.47 \\
\hline $\begin{array}{l}\text { PARKING } \\
\text { LOT } 2 \text { - } 3\end{array}$ & $10 / 04 / 2006$ & 3.50 & $<.52$ & 1.30 & $<.064$ & $<.049$ & $<.042$ & 1.20 & 2.60 & 15.25 \\
\hline $\begin{array}{l}\text { PARKING } \\
\text { LOT } 2 \text { - } 5\end{array}$ & 03/10/2007 & 1.40 & $<.52$ & 0.54 & $<.064$ & $<.049$ & $<.042$ & 0.39 & 1.00 & 6.12 \\
\hline $\begin{array}{l}\text { PARKING } \\
\text { LOT } 2 \text { - } 6\end{array}$ & $03 / 11 / 2007$ & 1.00 & $<.52$ & 0.41 & $<.064$ & $<.049$ & $<.042$ & 0.24 & 0.75 & 4.56 \\
\hline $\begin{array}{l}\text { PARKING } \\
\text { LOT } 2 \text { - } 7\end{array}$ & $03 / 12 / 2007$ & 1.10 & $<.52$ & 0.39 & $<.064$ & $<.049$ & $<.042$ & 0.32 & 0.78 & 4.76 \\
\hline $\begin{array}{l}\text { PARKING } \\
\text { LOT } 2 \text { - } 8\end{array}$ & $03 / 13 / 2007$ & 1.60 & $<.52$ & 0.61 & $<.064$ & $<.049$ & $<.042$ & 0.45 & 1.20 & 7.04 \\
\hline $\begin{array}{l}\text { PARKING } \\
\text { LOT } 2 \text { - } 9\end{array}$ & $03 / 31 / 2007$ & 6.10 & $<.52$ & 2.20 & $<.064$ & $<.049$ & $<.042$ & 2.50 & 4.50 & 27.99 \\
\hline $\begin{array}{l}\text { PARKING } \\
\text { LOT } 2 \text { - } 10\end{array}$ & $04 / 03 / 2007$ & 2.50 & $<.52$ & 0.93 & $<.064$ & $<.049$ & $<.042$ & 1.20 & 1.80 & 11.52 \\
\hline $\begin{array}{l}\text { PARKING } \\
\text { LOT } 2 \text { - } 11\end{array}$ & $04 / 24 / 2007$ & 0.65 & $<.52$ & 0.28 & $<.064$ & $<.049$ & $<.042$ & 0.20 & 0.43 & 2.97 \\
\hline $\begin{array}{l}\text { PARKING } \\
\text { LOT } 2 \text { - } 12\end{array}$ & $05 / 24 / 2007$ & 0.77 & $<.52$ & 0.32 & $<.064$ & $<.049$ & $<.042$ & 0.31 & 0.54 & 3.69 \\
\hline
\end{tabular}


Table 1-2. Concentrations of PAH compounds and total PAH summation for parking lot 3.

$[<$, less than; - , data not available; all values expressed as micrograms per liter; chemical nomenclature is that of the Wisconsin State Laboratory of Hygiene]

\begin{tabular}{|c|c|c|c|c|c|c|c|c|c|c|c|}
\hline Sample ID & Date & $\begin{array}{l}\text { Acenaph- } \\
\text { thene }\end{array}$ & $\begin{array}{l}\text { Acenaph- } \\
\text { thylene }\end{array}$ & Anthracene & $\begin{array}{c}\text { Benzo (A) } \\
\text { Anthracene }\end{array}$ & $\begin{array}{c}\text { Benzo (A) } \\
\text { Pyrene }\end{array}$ & $\begin{array}{c}\text { Benzo (B) } \\
\text { Fluoran- } \\
\text { thene }\end{array}$ & $\begin{array}{c}\text { Benzo } \\
(\mathrm{G}, \mathrm{H}, \mathrm{I},) \\
\text { Perylene }\end{array}$ & $\begin{array}{c}\text { Benzo (K) } \\
\text { Fluoran- } \\
\text { thene }\end{array}$ & Chrysene & $\begin{array}{c}\text { Dibenzo (A, } \\
\text { H) Anthra- } \\
\text { cene }\end{array}$ \\
\hline $\begin{array}{l}\text { PARKING } \\
\text { LOT } 3 \text { - } 1\end{array}$ & $04 / 29 / 2006$ & 0.08 & $<.11$ & 0.25 & 1.20 & 2.80 & 5.20 & 4.00 & 2.40 & 4.60 & $<.37$ \\
\hline $\begin{array}{l}\text { PARKING } \\
\text { LOT } 3 \text { - } 2\end{array}$ & $05 / 11 / 2006$ & $<.064$ & $<.11$ & 0.05 & 0.17 & 0.66 & 1.70 & 1.20 & 0.68 & 1.40 & $<.12$ \\
\hline $\begin{array}{l}\text { PARKING } \\
\text { LOT } 3 \text { - } 3\end{array}$ & $06 / 10 / 2006$ & $<.064$ & $<.11$ & 0.19 & $<.59$ & - & 4.00 & 3.00 & 1.70 & 3.60 & $<.28$ \\
\hline $\begin{array}{l}\text { PARKING } \\
\text { LOT } 3 \text { - } 4\end{array}$ & $06 / 25 / 2006$ & 0.16 & $<.11$ & - & $<1.0$ & 1.90 & 5.20 & 4.10 & 2.30 & 4.80 & $<.36$ \\
\hline $\begin{array}{l}\text { PARKING } \\
\text { LOT } 3 \text { - } 5\end{array}$ & $07 / 11 / 2006$ & $<.064$ & $<.11$ & 0.14 & $<.57$ & 0.78 & 3.40 & 2.60 & 1.50 & 3.10 & $<.23$ \\
\hline $\begin{array}{l}\text { PARKING } \\
\text { LOT } 3 \text { - } 6\end{array}$ & $07 / 20 / 2006$ & 0.09 & $<.11$ & - & 1.90 & - & 7.50 & 5.70 & 3.60 & 7.00 & $<.53$ \\
\hline $\begin{array}{l}\text { PARKING } \\
\text { LOT } 3 \text { - } 7\end{array}$ & $07 / 27 / 2006$ & 0.09 & $<.11$ & 0.30 & 2.00 & 3.80 & 5.80 & 4.80 & 2.70 & 5.20 & $<.47$ \\
\hline $\begin{array}{l}\text { PARKING } \\
\text { LOT } 3 \text { - } 8\end{array}$ & $08 / 23 / 2006$ & $<.064$ & $<.11$ & 0.30 & 1.80 & 5.50 & 8.10 & 6.30 & 3.70 & 7.10 & $<.60$ \\
\hline $\begin{array}{l}\text { PARKING } \\
\text { LOT } 3 \text { - } 9\end{array}$ & $08 / 24 / 2006$ & $<.064$ & $<.11$ & 0.24 & 1.50 & 3.90 & 5.40 & 4.30 & 2.50 & 4.70 & $<.45$ \\
\hline $\begin{array}{l}\text { PARKING } \\
\quad \text { LOT } 3 \text { - } 10\end{array}$ & $08 / 25 / 2006$ & $<.064$ & $<.11$ & 0.29 & 1.70 & 3.60 & 4.80 & 3.80 & 2.20 & 4.30 & $<.42$ \\
\hline $\begin{array}{l}\text { PARKING } \\
\quad \text { LOT } 3 \text { - } 11\end{array}$ & $04 / 23 / 2007$ & - & $<.11$ & 0.35 & 1.70 & 5.70 & 9.80 & 7.10 & 4.60 & 8.40 & $<.79$ \\
\hline $\begin{array}{l}\text { PARKING } \\
\text { LOT } 3 \text { - } 12\end{array}$ & $04 / 24 / 2007$ & $<.064$ & $<.11$ & 0.06 & 0.34 & 0.84 & 2.10 & 1.40 & 1.10 & 1.80 & $<.14$ \\
\hline
\end{tabular}


Table 1-2. Concentrations of PAH compounds and total PAH summation for parking lot 3-Continued.

$[<$, less than; - , data not available; all values expressed as micrograms per liter; chemical nomenclature is that of the Wisconsin State Laboratory of Hygiene]

\begin{tabular}{|c|c|c|c|c|c|c|c|c|c|c|}
\hline Sample ID & Date & $\begin{array}{c}\text { Fluoran- } \\
\text { thene }\end{array}$ & Fluorene & $\begin{array}{c}\text { Indeno } \\
(1.2 .3-C, D) \\
\text { Pyrene }\end{array}$ & $\begin{array}{c}\text { 1-Methyl- } \\
\text { naphthalene }\end{array}$ & $\begin{array}{c}\text { 2-Methyl- } \\
\text { naphthalene }\end{array}$ & Naphthalene & $\begin{array}{c}\text { Phenan- } \\
\text { threne }\end{array}$ & Pyrene & Total PAH \\
\hline $\begin{array}{l}\text { PARKING } \\
\text { LOT } 3 \text { - } 1\end{array}$ & $04 / 29 / 2006$ & 13.00 & $<.52$ & 3.80 & $<.064$ & $<.049$ & $<.042$ & 5.80 & 9.20 & 52.33 \\
\hline $\begin{array}{l}\text { PARKING } \\
\text { LOT } 3 \text { - } 2\end{array}$ & $05 / 11 / 2006$ & 3.70 & $<.52$ & 1.10 & $<.064$ & $<.049$ & $<.042$ & 1.40 & 2.50 & 14.56 \\
\hline $\begin{array}{l}\text { PARKING } \\
\text { LOT } 3 \text { - } 3\end{array}$ & $06 / 10 / 2006$ & 11.00 & $<.52$ & 2.80 & $<.064$ & $<.049$ & $<.042$ & 4.10 & 7.10 & 37.49 \\
\hline $\begin{array}{l}\text { PARKING } \\
\text { LOT } 3 \text { - } 4\end{array}$ & $06 / 25 / 2006$ & 15.00 & $<.52$ & 3.80 & $<.064$ & $<.049$ & $<.042$ & 7.30 & 10.00 & 54.56 \\
\hline $\begin{array}{l}\text { PARKING } \\
\text { LOT } 3 \text { - } 5\end{array}$ & $07 / 11 / 2006$ & 8.90 & $<.52$ & 2.40 & $<.064$ & $<.049$ & $<.042$ & 3.20 & 5.90 & 31.92 \\
\hline $\begin{array}{l}\text { PARKING } \\
\text { LOT } 3-6\end{array}$ & $07 / 20 / 2006$ & 19.00 & $<.52$ & 5.30 & $<.064$ & $<.049$ & $<.042$ & 7.20 & 14.00 & 71.29 \\
\hline $\begin{array}{l}\text { PARKING } \\
\text { LOT } 3-7\end{array}$ & $07 / 27 / 2006$ & 13.00 & $<.52$ & 4.30 & $<.064$ & $<.049$ & $<.042$ & 5.20 & 10.00 & 57.19 \\
\hline $\begin{array}{l}\text { PARKING } \\
\text { LOT } 3-8\end{array}$ & $08 / 23 / 2006$ & 18.00 & $<.52$ & 5.90 & $<.064$ & $<.049$ & $<.042$ & 6.30 & 13.00 & 76.00 \\
\hline $\begin{array}{l}\text { PARKING } \\
\text { LOT } 3 \text { - } 9\end{array}$ & $08 / 24 / 2006$ & 12.00 & $<.52$ & 4.10 & $<.064$ & $<.049$ & $<.042$ & 4.20 & 9.00 & 51.84 \\
\hline $\begin{array}{l}\text { PARKING } \\
\quad \text { LOT } 3 \text { - } 10\end{array}$ & $08 / 25 / 2006$ & 11.00 & $<.52$ & 3.50 & $<.064$ & $<.049$ & $<.042$ & 4.00 & 8.70 & 47.89 \\
\hline $\begin{array}{l}\text { PARKING } \\
\quad \text { LOT } 3 \text { - } 11\end{array}$ & $04 / 23 / 2007$ & 24.00 & $<.52$ & 5.80 & $<.064$ & 0.11 & $<.042$ & 11.00 & 17.00 & 95.56 \\
\hline $\begin{array}{l}\text { PARKING } \\
\text { LOT } 3-12\end{array}$ & $04 / 24 / 2007$ & 4.50 & $<.52$ & 1.20 & $<.064$ & $<.049$ & $<.042$ & 1.90 & 3.10 & 18.34 \\
\hline
\end{tabular}


Table 1-2. Concentrations of PAH compounds and total PAH summation for parking lot 3-Continued.

$[<$, less than; - , data not available; all values expressed as micrograms per liter; chemical nomenclature is that of the Wisconsin State Laboratory of Hygiene]

\begin{tabular}{|c|c|c|c|c|c|c|c|c|c|c|c|}
\hline Sample ID & Date & $\begin{array}{l}\text { Acenaph- } \\
\text { thene }\end{array}$ & $\begin{array}{l}\text { Acenaph- } \\
\text { thylene }\end{array}$ & Anthracene & $\begin{array}{c}\text { Benzo (A) } \\
\text { Anthracene }\end{array}$ & $\begin{array}{c}\text { Benzo (A) } \\
\text { Pyrene }\end{array}$ & $\begin{array}{c}\text { Benzo (B) } \\
\text { Fluoran- } \\
\text { thene }\end{array}$ & $\begin{array}{c}\text { Benzo } \\
(\mathbf{G}, \mathbf{H}, \mathbf{I},) \\
\text { Perylene }\end{array}$ & $\begin{array}{c}\text { Benzo (K) } \\
\text { Fluoran- } \\
\text { thene }\end{array}$ & Chrysene & $\begin{array}{l}\text { Dibenzo (A, } \\
\text { H) Anthra- } \\
\text { cene }\end{array}$ \\
\hline $\begin{array}{l}\text { PARKING } \\
\quad \text { LOT } 3 \text { - } 13\end{array}$ & $05 / 15 / 2007$ & 0.17 & $<.11$ & 0.25 & 1.10 & 3.70 & 6.40 & 4.40 & 2.80 & 5.50 & 0.47 \\
\hline $\begin{array}{l}\text { PARKING } \\
\quad \text { LOT } 3 \text { - } 14\end{array}$ & $05 / 24 / 2007$ & $<.064$ & $<.11$ & $<.28$ & - & 6.10 & 10.00 & 7.40 & 4.80 & 8.80 & $<.58$ \\
\hline $\begin{array}{l}\text { PARKING } \\
\text { LOT } 3-15\end{array}$ & 07/03/2007 & 0.11 & $<.11$ & 0.25 & 0.97 & 2.40 & 3.80 & 2.80 & 1.80 & 3.60 & $<.22$ \\
\hline
\end{tabular}

Table 1-2. Concentrations of PAH compounds and total PAH summation for parking lot 3-Continued.

$[<$, less than; - , data not available; all values expressed as micrograms per liter; chemical nomenclature is that of the Wisconsin State Laboratory of Hygiene]

\begin{tabular}{ccccccccccc}
\hline Sample ID & Date & $\begin{array}{c}\text { Fluoran- } \\
\text { thene }\end{array}$ & Fluorene & $\begin{array}{c}\text { Indeno } \\
(\mathbf{1 . 2 . 3 - C , D )} \\
\text { Pyrene }\end{array}$ & $\begin{array}{c}\text { 1-Methyl- } \\
\text { naphthalene }\end{array}$ & $\begin{array}{c}\text { 2-Methyl- } \\
\text { naphthalene }\end{array}$ & Naphthalene & $\begin{array}{c}\text { Phenan- } \\
\text { threne }\end{array}$ & Pyrene & Total PAH \\
\hline $\begin{array}{c}\text { PARKING } \\
\text { LOT 3 - 13 }\end{array}$ & $05 / 15 / 2007$ & 18.00 & $<.52$ & 3.60 & $<.064$ & 0.09 & $<.042$ & 6.60 & 11.00 & 64.08 \\
$\begin{array}{c}\text { PARKING } \\
\text { LOT 3 - 14 }\end{array}$ & $05 / 24 / 2007$ & 25.00 & $<.52$ & 6.20 & $<.064$ & 0.09 & $<.042$ & 8.80 & 17.00 & 94.19 \\
$\begin{array}{c}\text { PARKING } \\
\text { LOT 3 - 15 }\end{array}$ & $07 / 03 / 2007$ & 11.00 & $<.52$ & 2.40 & $<.064$ & 0.09 & $<.042$ & 4.10 & 7.30 & 40.62 \\
\hline
\end{tabular}


Table 1-3. Concentrations of PAH compounds and total PAH summation for feeder street.

$[<$, less than; - , data not available; all values expressed as micrograms per liter; chemical nomenclature is that of the Wisconsin State Laboratory of Hygiene]

\begin{tabular}{|c|c|c|c|c|c|c|c|c|c|c|c|}
\hline Sample ID & Date & $\begin{array}{l}\text { Acenaph- } \\
\text { thene }\end{array}$ & $\begin{array}{l}\text { Acenaph- } \\
\text { thylene }\end{array}$ & Anthracene & $\begin{array}{c}\text { Benzo (A) } \\
\text { Anthracene }\end{array}$ & $\begin{array}{l}\text { Benzo (A) } \\
\text { Pyrene }\end{array}$ & $\begin{array}{c}\text { Benzo (B) } \\
\text { Fluoran- } \\
\text { thene }\end{array}$ & $\begin{array}{c}\text { Benzo } \\
(\mathrm{G}, \mathrm{H}, \mathrm{I},) \\
\text { Perylene }\end{array}$ & $\begin{array}{c}\text { Benzo (K) } \\
\text { Fluoran- } \\
\text { thene }\end{array}$ & Chrysene & $\begin{array}{c}\text { Dibenzo (A, } \\
\text { H) Anthra- } \\
\text { cene }\end{array}$ \\
\hline FEEDER - 1 & 08/14/2007 & $<.064$ & $<.11$ & $<.031$ & $<.093$ & $<.16$ & $<.13$ & $<.14$ & $<.12$ & 0.04 & $<.034$ \\
\hline FEEDER - 2 & 08/18/2007 & $<.064$ & $<.11$ & $<.031$ & $<.093$ & $<.16$ & $<.13$ & $<.14$ & $<.12$ & 0.03 & $<.034$ \\
\hline FEEDER - 3 & 09/06/2007 & $<.064$ & $<.11$ & $<.031$ & $<.093$ & $<.16$ & $<.13$ & $<.14$ & $<.12$ & 0.06 & $<.034$ \\
\hline FEEDER - 4 & 09/21/2007 & $<.064$ & $<.11$ & $<.031$ & $<.093$ & $<.16$ & $<.13$ & - & $<.12$ & 0.08 & $<.034$ \\
\hline FEEDER - 5 & 09/25/2007 & $<.064$ & $<.11$ & $<.031$ & $<.093$ & $<.16$ & $<.13$ & $<.14$ & $<.12$ & 0.05 & $<.034$ \\
\hline FEEDER - 6 & $10 / 02 / 2007$ & $<.064$ & $<.11$ & $<.031$ & $<.093$ & $<.16$ & $<.13$ & $<.14$ & $<.12$ & $<.027$ & $<.034$ \\
\hline FEEDER - 7 & $10 / 15 / 2007$ & $<.064$ & $<.11$ & $<.031$ & $<.093$ & $<.16$ & $<.13$ & $<.14$ & $<.12$ & $<.027$ & $<.034$ \\
\hline FEEDER - 8 & $10 / 17 / 2007$ & $<.064$ & $<.11$ & $<.031$ & $<.093$ & $<.16$ & $<.13$ & $<.14$ & $<.12$ & $<.027$ & $<.034$ \\
\hline FEEDER - 9 & $04 / 10 / 2008$ & $<.064$ & $<.11$ & 0.05 & 0.30 & 0.50 & 0.65 & 0.57 & 0.32 & 0.53 & $<.080$ \\
\hline FEEDER - 10 & $04 / 24 / 2008$ & $<.064$ & $<.11$ & $<.15$ & 0.58 & 0.85 & 1.30 & 1.10 & 0.40 & 1.00 & $<.16$ \\
\hline FEEDER - 11 & $05 / 02 / 2008$ & $<.064$ & $<.11$ & $<.045$ & 0.28 & 0.45 & 0.65 & 0.59 & 0.24 & 0.55 & $<.080$ \\
\hline FEEDER - 12 & 05/06/2008 & $<.064$ & $<.11$ & $<.031$ & $<.093$ & $<.16$ & $<.13$ & $<.14$ & $<.12$ & 0.04 & $<.034$ \\
\hline FEEDER - 13 & 05/29/2008 & $<.064$ & $<.11$ & $<.031$ & $<.093$ & $<.16$ & $<.13$ & $<.14$ & $<.12$ & 0.06 & $<.034$ \\
\hline FEEDER - 14 & 06/05/2008 & $<.064$ & $<.11$ & $<.031$ & 0.40 & 0.70 & 0.80 & 0.82 & 0.24 & 0.73 & $<.12$ \\
\hline FEEDER - 15 & $06 / 12 / 2008$ & $<.064$ & $<.11$ & $<.031$ & 0.14 & 0.25 & 0.27 & 0.25 & $<.12$ & 0.19 & $<.035$ \\
\hline
\end{tabular}


Table 1-3. Concentrations of PAH compounds and total PAH summation for feeder street-Continued.

$[<$, less than; - , data not available; all values expressed as micrograms per liter; chemical nomenclature is that of the Wisconsin State Laboratory of Hygiene]

\begin{tabular}{|c|c|c|c|c|c|c|c|c|c|c|}
\hline Sample ID & Date & $\begin{array}{c}\text { Fluoran- } \\
\text { thene }\end{array}$ & Fluorene & $\begin{array}{c}\text { Indeno } \\
\text { (1.2.3-C,D) } \\
\text { Pyrene } \\
\end{array}$ & $\begin{array}{c}\text { 1-Methyl- } \\
\text { naphthalene }\end{array}$ & $\begin{array}{c}\text { 2-Methyl- } \\
\text { naphthalene }\end{array}$ & Naphthalene & $\begin{array}{l}\text { Phenan- } \\
\text { threne }\end{array}$ & Pyrene & Total PAH \\
\hline FEEDER - 1 & $08 / 14 / 2007$ & $<.11$ & $<.52$ & $<.093$ & $<.1$ & $<.049$ & $<.042$ & $<.093$ & $<.11$ & 0.04 \\
\hline FEEDER - 2 & $08 / 18 / 2007$ & $<.11$ & $<.52$ & $<.093$ & $<.1$ & $<.049$ & $<.042$ & $<.093$ & $<.11$ & 0.03 \\
\hline FEEDER - 3 & $09 / 06 / 2007$ & - & $<.52$ & $<.093$ & $<.1$ & $<.049$ & $<.042$ & $<.093$ & - & 0.06 \\
\hline FEEDER - 4 & $09 / 21 / 2007$ & - & $<.52$ & $<.14$ & $<.1$ & $<.049$ & $<.042$ & $<.093$ & - & 0.08 \\
\hline FEEDER - 5 & $09 / 25 / 2007$ & $<.11$ & $<.52$ & $<.093$ & $<.1$ & $<.049$ & $<.042$ & $<.093$ & $<.11$ & 0.05 \\
\hline FEEDER - 6 & $10 / 02 / 2007$ & $<.11$ & $<.52$ & $<.093$ & $<.1$ & $<.049$ & $<.042$ & $<.093$ & $<.11$ & - \\
\hline FEEDER - 7 & $10 / 15 / 2007$ & $<.11$ & $<.52$ & $<.093$ & $<.1$ & $<.049$ & $<.042$ & $<.093$ & $<.11$ & - \\
\hline FEEDER - 8 & $10 / 17 / 2007$ & $<.11$ & $<.52$ & $<.093$ & $<.1$ & $<.049$ & $<.042$ & $<.093$ & $<.11$ & - \\
\hline FEEDER - 9 & $04 / 10 / 2008$ & 1.40 & $<.52$ & 0.47 & $<.064$ & $<.049$ & $<.042$ & 0.62 & 1.00 & 6.41 \\
\hline FEEDER - 10 & $04 / 24 / 2008$ & 2.70 & $<.52$ & $<1.2$ & $<.064$ & $<.049$ & $<.042$ & 1.30 & 1.90 & 11.13 \\
\hline FEEDER - 11 & $05 / 02 / 2008$ & 1.20 & $<.52$ & 0.56 & $<.064$ & $<.049$ & $<.042$ & 0.51 & 0.91 & 5.94 \\
\hline FEEDER - 12 & $05 / 06 / 2008$ & $<.11$ & $<.52$ & $<.093$ & $<.064$ & $<.049$ & $<.042$ & $<.093$ & $<.11$ & 0.04 \\
\hline FEEDER - 13 & $05 / 29 / 2008$ & 0.12 & $<.52$ & $<.15$ & $<.064$ & $<.049$ & $<.042$ & $<.093$ & $<.11$ & 0.18 \\
\hline FEEDER - 14 & $06 / 05 / 2008$ & 1.60 & $<.52$ & 0.86 & $<.064$ & $<.049$ & $<.042$ & 0.99 & 1.40 & 8.54 \\
\hline FEEDER - 15 & $06 / 12 / 2008$ & 0.46 & $<.52$ & 0.26 & $<.064$ & $<.049$ & $<.042$ & 0.22 & 0.39 & 2.43 \\
\hline
\end{tabular}


Table 1-4. Concentrations of PAH compounds and total PAH summation for collector street.

$[<$, less than; - , data not available; all values expressed as micrograms per liter; chemical nomenclature is that of the Wisconsin State Laboratory of Hygiene]

\begin{tabular}{|c|c|c|c|c|c|c|c|c|c|c|c|}
\hline Sample ID & Date & $\begin{array}{l}\text { Acenaph- } \\
\text { thene }\end{array}$ & $\begin{array}{l}\text { Acenaph- } \\
\text { thylene }\end{array}$ & Anthracene & $\begin{array}{c}\text { Benzo (A) } \\
\text { Anthracene }\end{array}$ & $\begin{array}{c}\text { Benzo (A) } \\
\text { Pyrene }\end{array}$ & $\begin{array}{c}\text { Benzo (B) } \\
\text { Fluoran- } \\
\text { thene }\end{array}$ & $\begin{array}{c}\text { Benzo } \\
(\mathrm{G}, \mathrm{H}, \mathrm{I},) \\
\text { Perylene }\end{array}$ & $\begin{array}{c}\text { Benzo (K) } \\
\text { Fluoran- } \\
\text { thene }\end{array}$ & Chrysene & $\begin{array}{c}\text { Dibenzo (A, } \\
\text { H) Anthra- } \\
\text { cene }\end{array}$ \\
\hline COLLECTOR - 1 & $07 / 26 / 2007$ & $<.064$ & $<.11$ & $<.031$ & $<.093$ & $<.16$ & $<.13$ & $<.14$ & $<.12$ & 0.11 & $<.034$ \\
\hline COLLECTOR - 2 & 08/04/2007 & $<.064$ & $<.11$ & $<.031$ & $<.093$ & $<.16$ & $<.13$ & $<.14$ & $<.12$ & $<.027$ & $<.034$ \\
\hline COLLECTOR - 3 & $08 / 14 / 2007$ & $<.064$ & $<.11$ & $<.031$ & 0.21 & 0.31 & 0.43 & 0.36 & 0.21 & 0.39 & $<0.049$ \\
\hline COLLECTOR - 4 & 08/18/2007 & $<.064$ & $<.11$ & 0.07 & 0.29 & 0.36 & 0.42 & 0.38 & 0.20 & 0.39 & $<0.055$ \\
\hline COLLECTOR - 5 & $08 / 22 / 2007$ & $<.064$ & $<.11$ & $<.031$ & $<.093$ & $<.16$ & 0.29 & 0.26 & $<.12$ & 0.22 & $<0.035$ \\
\hline COLLECTOR - 6 & 08/27/2007 & $<.064$ & $<.11$ & $<.031$ & $<.093$ & $<.16$ & $<.13$ & $<.14$ & $<.12$ & 0.09 & $<.034$ \\
\hline COLLECTOR - 7 & 09/21/2007 & $<.064$ & $<.11$ & $<.031$ & 0.29 & 0.40 & 0.50 & 0.46 & 0.26 & 0.46 & $<0.056$ \\
\hline COLLECTOR - 8 & $10 / 02 / 2007$ & $<.064$ & $<.11$ & $<.031$ & 0.14 & 0.22 & 0.32 & 0.30 & $<.12$ & 0.27 & $<0.043$ \\
\hline COLLECTOR - 9 & $10 / 15 / 2007$ & $<.064$ & $<.11$ & $<.031$ & $<.093$ & $<.16$ & $<.13$ & $<.14$ & $<.12$ & 0.06 & $<.034$ \\
\hline COLLECTOR - 10 & $10 / 17 / 2007$ & $<.064$ & $<.11$ & $<.031$ & $<.093$ & $<.16$ & $<.13$ & $<.14$ & $<.12$ & 0.08 & $<.034$ \\
\hline COLLECTOR - 11 & $03 / 31 / 2008$ & 0.12 & $<.11$ & 0.42 & 1.60 & 2.90 & 4.50 & 3.60 & 2.10 & 3.70 & $<.50$ \\
\hline COLLECTOR - 12 & 04/08/2008 & $<.064$ & $<.11$ & $<.031$ & 0.13 & 0.29 & 0.56 & 0.47 & 0.24 & 0.41 & $<.071$ \\
\hline COLLECTOR - 13 & 04/10/2008 & $<.064$ & $<.11$ & 0.08 & 0.41 & 0.64 & 0.99 & 0.83 & 0.47 & 0.81 & $<.13$ \\
\hline COLLECTOR - 14 & $04 / 24 / 2008$ & 0.22 & $<.11$ & $<.50$ & 2.20 & 2.90 & 3.40 & 2.60 & 1.30 & 2.90 & $<.36$ \\
\hline
\end{tabular}


Table 1-4. Concentrations of PAH compounds and total PAH summation for collector street-Continued.

$[<$, less than; - , data not available; all values expressed as micrograms per liter; chemical nomenclature is that of the Wisconsin State Laboratory of Hygiene]

\begin{tabular}{|c|c|c|c|c|c|c|c|c|c|c|}
\hline Sample ID & Date & $\begin{array}{l}\text { Fluoran- } \\
\text { thene }\end{array}$ & Fluorene & $\begin{array}{c}\text { Indeno } \\
(1.2 .3-C, D) \\
\text { Pyrene }\end{array}$ & $\begin{array}{c}\text { 1-Methyl- } \\
\text { naphthalene }\end{array}$ & $\begin{array}{c}\text { 2-Methyl- } \\
\text { naphthalene }\end{array}$ & Naphthalene & $\begin{array}{l}\text { Phenan- } \\
\text { threne }\end{array}$ & Pyrene & Total PAH \\
\hline COLLECTOR - 1 & $07 / 26 / 2007$ & 0.25 & $<.52$ & $<.093$ & $<.064$ & $<.049$ & $<.042$ & $<.093$ & 0.15 & 0.51 \\
\hline COLLECTOR - 2 & 08/04/2007 & $<.11$ & $<.52$ & $<.093$ & $<.064$ & $<.049$ & $<.042$ & $<.093$ & $<.11$ & - \\
\hline COLLECTOR - 3 & $08 / 14 / 2007$ & 0.93 & $<.52$ & 0.31 & $<.064$ & $<.049$ & $<.042$ & 0.33 & 0.69 & 4.17 \\
\hline COLLECTOR - 4 & 08/18/2007 & 1.10 & $<.52$ & 0.33 & $<.064$ & $<.049$ & $<.042$ & 0.53 & 0.80 & 4.87 \\
\hline COLLECTOR - 5 & $08 / 22 / 2007$ & 0.44 & $<.52$ & 0.20 & $<.064$ & $<.049$ & $<.042$ & 0.11 & 0.31 & 1.83 \\
\hline COLLECTOR - 6 & $08 / 27 / 2007$ & 0.23 & $<.52$ & $<0.11$ & $<.064$ & $<.049$ & $<.042$ & $<.093$ & 0.16 & 0.48 \\
\hline COLLECTOR - 7 & $09 / 21 / 2007$ & 1.00 & $<.52$ & 0.36 & $<.064$ & $<.049$ & $<.042$ & 0.34 & 0.76 & 4.83 \\
\hline COLLECTOR - 8 & $10 / 02 / 2007$ & 0.64 & $<.52$ & 0.23 & $<.064$ & $<.049$ & $<.042$ & 0.23 & 0.48 & 2.83 \\
\hline COLLECTOR - 9 & $10 / 15 / 2007$ & 0.13 & $<.52$ & $<.093$ & $<.064$ & $<.049$ & $<.042$ & $<.093$ & $<.11$ & 0.19 \\
\hline COLLECTOR - 10 & $10 / 17 / 2007$ & 0.18 & $<.52$ & 0.12 & $<.064$ & $<.049$ & $<.042$ & $<.093$ & 0.14 & 0.52 \\
\hline COLLECTOR - 11 & $03 / 31 / 2008$ & 9.60 & $<.52$ & 2.90 & $<.064$ & 0.12 & 0.06 & 4.20 & 7.10 & 42.92 \\
\hline COLLECTOR - 12 & $04 / 08 / 2008$ & 1.00 & $<.52$ & 0.40 & $<.064$ & $<.049$ & $<.042$ & 0.42 & 0.69 & 4.61 \\
\hline COLLECTOR - 13 & $04 / 10 / 2008$ & 2.10 & $<.52$ & 0.65 & $<.064$ & $<.049$ & $<.042$ & 0.95 & 1.60 & 9.53 \\
\hline COLLECTOR - 14 & $04 / 24 / 2008$ & 8.40 & $<.52$ & 2.80 & $<.064$ & 0.07 & $<.042$ & 4.50 & 5.90 & 37.19 \\
\hline
\end{tabular}


Table 1-4. Concentrations of PAH compounds and total PAH summation for collector street-Continued.

$[<$, less than; - , data not available; all values expressed as micrograms per liter; chemical nomenclature is that of the Wisconsin State Laboratory of Hygiene]

\begin{tabular}{|c|c|c|c|c|c|c|c|c|c|c|c|}
\hline Sample ID & Date & $\begin{array}{l}\text { Acenaph- } \\
\text { thene }\end{array}$ & $\begin{array}{l}\text { Acenaph- } \\
\text { thylene }\end{array}$ & Anthracene & $\begin{array}{c}\text { Benzo (A) } \\
\text { Anthracene }\end{array}$ & $\begin{array}{c}\text { Benzo (A) } \\
\text { Pyrene }\end{array}$ & $\begin{array}{c}\text { Benzo (B) } \\
\text { Fluoran- } \\
\text { thene }\end{array}$ & $\begin{array}{c}\text { Benzo } \\
(\mathrm{G}, \mathrm{H}, \mathrm{I},) \\
\text { Perylene }\end{array}$ & $\begin{array}{c}\text { Benzo (K) } \\
\text { Fluoran- } \\
\text { thene }\end{array}$ & Chrysene & $\begin{array}{c}\text { Dibenzo (A, } \\
\text { H) Anthra- } \\
\text { cene }\end{array}$ \\
\hline COLLECTOR - 15 & $04 / 25 / 2008$ & $<.064$ & $<.11$ & $<.063$ & 0.35 & 0.49 & 0.69 & 0.58 & 0.27 & 0.59 & $<.078$ \\
\hline COLLECTOR - 16 & $05 / 30 / 2008$ & $<.064$ & $<.11$ & $<.031$ & 0.24 & 0.40 & 0.53 & 0.47 & 0.20 & 0.41 & $<0.065$ \\
\hline COLLECTOR - 17 & $06 / 05 / 2008$ & $<.064$ & $<.11$ & $<.031$ & 0.14 & 0.26 & 0.29 & 0.27 & $<.12$ & 0.23 & $<0.038$ \\
\hline
\end{tabular}

Table 1-4. Concentrations of PAH compounds and total PAH summation for collector street-Continued.

$[<$, less than; - - data not available; all values expressed as micrograms per liter; chemical nomenclature is that of the Wisconsin State Laboratory of Hygiene]

\begin{tabular}{|c|c|c|c|c|c|c|c|c|c|c|}
\hline Sample ID & Date & $\begin{array}{c}\text { Fluoran- } \\
\text { thene }\end{array}$ & Fluorene & $\begin{array}{c}\text { Indeno } \\
(1.2 .3-C, D) \\
\text { Pyrene }\end{array}$ & $\begin{array}{c}\text { 1-Methyl- } \\
\text { naphthalene }\end{array}$ & $\begin{array}{c}\text { 2-Methyl- } \\
\text { naphthalene }\end{array}$ & Naphthalene & $\begin{array}{c}\text { Phenan- } \\
\text { threne }\end{array}$ & Pyrene & Total PAH \\
\hline COLLECTOR - 15 & $04 / 25 / 2008$ & 1.50 & $<.52$ & 0.59 & $<.064$ & $<.049$ & $<.042$ & 0.68 & 1.10 & 6.84 \\
\hline COLLECTOR - 16 & $05 / 30 / 2008$ & 1.00 & $<.52$ & 0.48 & $<.064$ & $<.049$ & $<.042$ & 0.36 & 0.75 & 4.84 \\
\hline COLLECTOR - 17 & $06 / 05 / 2008$ & 0.54 & $<.52$ & 0.29 & $<.064$ & $<.049$ & $<.042$ & 0.18 & 0.41 & 2.61 \\
\hline
\end{tabular}


Table 1-5. Concentrations of PAH compounds and total PAH summation for arterial street.

$[<$, less than; all values expressed as micrograms per liter; chemical nomenclature is that of the Wisconsin State Laboratory of Hygiene]

\begin{tabular}{|c|c|c|c|c|c|c|c|c|c|c|c|}
\hline Sample ID & Date & $\begin{array}{l}\text { Acenaph- } \\
\text { thene }\end{array}$ & $\begin{array}{l}\text { Acenaph- } \\
\text { thylene }\end{array}$ & Anthracene & $\begin{array}{c}\text { Benzo (A) } \\
\text { Anthracene }\end{array}$ & $\begin{array}{c}\text { Benzo (A) } \\
\text { Pyrene }\end{array}$ & $\begin{array}{c}\text { Benzo (B) } \\
\text { Fluoran- } \\
\text { thene }\end{array}$ & $\begin{array}{c}\text { Benzo } \\
(\mathrm{G}, \mathrm{H}, \mathrm{I},) \\
\text { Perylene }\end{array}$ & $\begin{array}{c}\text { Benzo (K) } \\
\text { Fluoran- } \\
\text { thene }\end{array}$ & Chrysene & $\begin{array}{c}\text { Dibenzo (A, } \\
\text { H) Anthra- } \\
\text { cene }\end{array}$ \\
\hline ARTERIAL - 1 & $05 / 11 / 2005$ & $<.064$ & $<.11$ & $<.031$ & $<.093$ & 0.17 & 0.24 & 0.27 & $<.12$ & 0.20 & $<.060$ \\
\hline ARTERIAL - 2 & $05 / 19 / 2005$ & 0.16 & $<.11$ & 0.56 & 4.00 & 6.80 & 12.00 & 7.70 & 4.80 & 9.10 & $<1.2$ \\
\hline ARTERIAL - 3 & $07 / 20 / 2005$ & $<.064$ & $<.11$ & 0.31 & 1.90 & 3.70 & 5.10 & 4.20 & 2.40 & 4.30 & $<1.0$ \\
\hline ARTERIAL - 4 & $07 / 21 / 2005$ & $<.064$ & $<.11$ & 0.08 & 0.44 & 0.81 & 1.20 & 0.99 & 0.56 & 1.00 & $<.17$ \\
\hline ARTERIAL - 5 & $04 / 29 / 2006$ & $<.064$ & $<.11$ & 0.04 & 0.25 & 0.41 & 0.67 & 0.56 & 0.30 & 0.54 & $<.076$ \\
\hline ARTERIAL - 6 & $05 / 09 / 2006$ & $<.064$ & $<.11$ & 0.05 & 0.32 & 0.56 & 0.93 & 0.81 & 0.40 & 0.75 & $<.096$ \\
\hline ARTERIAL - 7 & $05 / 11 / 2006$ & $<.064$ & $<.11$ & $<.031$ & 0.14 & 0.32 & 0.48 & 0.47 & 0.23 & 0.40 & $<.064$ \\
\hline ARTERIAL - 8 & $05 / 24 / 2006$ & 0.13 & $<.11$ & 0.40 & 2.80 & 4.50 & 7.00 & 5.60 & 3.20 & 5.70 & $<.68$ \\
\hline ARTERIAL - 9 & $06 / 09 / 2006$ & $<.064$ & $<.11$ & $<.031$ & $<.093$ & - & 0.37 & 0.39 & 0.17 & 0.29 & $<.054$ \\
\hline ARTERIAL - 10 & $06 / 25 / 2006$ & $<.064$ & $<.11$ & $<.031$ & 0.12 & 0.28 & 0.44 & 0.46 & 0.19 & 0.33 & $<.081$ \\
\hline ARTERIAL - 11 & $07 / 11 / 2006$ & $<.064$ & $<.11$ & 0.05 & 0.23 & 0.47 & 0.56 & 0.55 & 0.25 & 0.44 & $<.058$ \\
\hline
\end{tabular}


Table 1-5. Concentrations of PAH compounds and total PAH summation for arterial street-Continued.

$[<$, less than; all values expressed as micrograms per liter; chemical nomenclature is that of the Wisconsin State Laboratory of Hygiene]

\begin{tabular}{|c|c|c|c|c|c|c|c|c|c|c|}
\hline Sample ID & Date & $\begin{array}{c}\text { Fluoran- } \\
\text { thene }\end{array}$ & Fluorene & $\begin{array}{c}\text { Indeno } \\
(1.2 .3-C, D) \\
\text { Pyrene }\end{array}$ & $\begin{array}{c}\text { 1-Methyl- } \\
\text { naphthalene }\end{array}$ & $\begin{array}{c}\text { 2-Methyl- } \\
\text { naphthalene }\end{array}$ & Naphthalene & $\begin{array}{l}\text { Phenan- } \\
\text { threne }\end{array}$ & Pyrene & Total PAH \\
\hline ARTERIAL - 1 & $05 / 11 / 2005$ & 0.49 & $<.52$ & 0.23 & $<.064$ & $<.049$ & $<.042$ & 0.12 & 0.33 & 2.05 \\
\hline ARTERIAL - 2 & $05 / 19 / 2005$ & 22.00 & $<.52$ & 7.30 & $<.064$ & $<.049$ & 0.04 & 8.50 & 16.00 & 98.96 \\
\hline ARTERIAL - 3 & $07 / 20 / 2005$ & 9.60 & $<.52$ & 3.80 & $<.064$ & $<.049$ & $<.042$ & 3.00 & 6.40 & 44.71 \\
\hline ARTERIAL - 4 & $07 / 21 / 2005$ & 2.20 & $<.52$ & 0.90 & $<.064$ & $<.049$ & $<.042$ & 0.64 & 1.50 & 10.32 \\
\hline ARTERIAL - 5 & $04 / 29 / 2006$ & 1.20 & $<.52$ & 0.51 & $<.064$ & $<.049$ & $<.042$ & 0.37 & 0.87 & 5.72 \\
\hline ARTERIAL - 6 & $05 / 09 / 2006$ & 1.60 & $<.52$ & 0.72 & $<.064$ & $<.049$ & $<.042$ & 0.42 & 1.20 & 7.76 \\
\hline ARTERIAL - 7 & $05 / 11 / 2006$ & 0.89 & $<.52$ & 0.38 & $<.064$ & $<.049$ & $<.042$ & 0.22 & 0.67 & 4.20 \\
\hline ARTERIAL - 8 & $05 / 24 / 2006$ & 13.00 & $<.52$ & 5.30 & $<.064$ & $<.049$ & 0.05 & 5.00 & 10.00 & 62.68 \\
\hline ARTERIAL - 9 & $06 / 09 / 2006$ & 0.59 & $<.52$ & 0.31 & $<.064$ & $<.049$ & $<.042$ & 0.24 & 0.40 & 2.76 \\
\hline ARTERIAL - 10 & $06 / 25 / 2006$ & 0.65 & $<.52$ & 0.36 & $<.064$ & $<.049$ & $<.042$ & 0.23 & 0.50 & 3.56 \\
\hline ARTERIAL - 11 & $07 / 11 / 2006$ & 0.88 & $<.52$ & 0.44 & $<.064$ & $<.049$ & $<.042$ & 0.41 & 0.69 & 4.97 \\
\hline
\end{tabular}


Table 1-6. Concentrations of PAH compounds and total PAH summation for commercial roof.

$[<$, less than; all values expressed as micrograms per liter; chemical nomenclature is that of the Wisconsin State Laboratory of Hygiene]

\begin{tabular}{|c|c|c|c|c|c|c|c|c|c|c|c|}
\hline Sample ID & Date & $\begin{array}{l}\text { Acenaph- } \\
\text { thene }\end{array}$ & $\begin{array}{l}\text { Acenaph- } \\
\text { thylene }\end{array}$ & Anthracene & $\begin{array}{c}\text { Benzo (A) } \\
\text { Anthracene }\end{array}$ & $\begin{array}{c}\text { Benzo (A) } \\
\text { Pyrene }\end{array}$ & $\begin{array}{c}\text { Benzo (B) } \\
\text { Fluoran- } \\
\text { thene }\end{array}$ & $\begin{array}{c}\text { Benzo } \\
(\mathbf{G}, \mathrm{H}, \mathrm{I},) \\
\text { Perylene }\end{array}$ & $\begin{array}{c}\text { Benzo (K) } \\
\text { Fluoran- } \\
\text { thene }\end{array}$ & Chrysene & $\begin{array}{l}\text { Dibenzo ( } A \\
\text { H) Anthra- } \\
\text { cene }\end{array}$ \\
\hline $\begin{array}{l}\text { COMMERCIAL } \\
\text { ROOF-1 }\end{array}$ & $08 / 17 / 2006$ & $<.064$ & $<.11$ & $<.031$ & $<.093$ & 0.19 & 0.22 & 0.26 & $<.12$ & 0.16 & $<.034$ \\
\hline $\begin{array}{l}\text { COMMERCIAL } \\
\text { ROOF-2 }\end{array}$ & $08 / 28 / 2006$ & $<.064$ & $<.11$ & $<.031$ & $<.093$ & $<.16$ & $<.13$ & $<.14$ & $<.12$ & $<0.031$ & $<.034$ \\
\hline $\begin{array}{l}\text { COMMERCIAL } \\
\text { ROOF-3 }\end{array}$ & $10 / 04 / 2006$ & $<.064$ & $<.11$ & $<.031$ & $<.093$ & 0.24 & 0.27 & 0.24 & $<.12$ & 0.21 & $<.034$ \\
\hline $\begin{array}{l}\text { COMMERCIAL } \\
\text { ROOF-4 }\end{array}$ & $10 / 10 / 2006$ & $<.064$ & $<.11$ & $<.031$ & 0.16 & 0.29 & 0.33 & 0.29 & $<.12$ & 0.27 & $<.034$ \\
\hline $\begin{array}{l}\text { COMMERCIAL } \\
\text { ROOF-5 }\end{array}$ & $10 / 16 / 2006$ & $<.064$ & $<.11$ & $<.031$ & 0.11 & 0.21 & 0.23 & 0.20 & $<.12$ & 0.17 & $<.034$ \\
\hline $\begin{array}{l}\text { COMMERCIAL } \\
\text { ROOF-6 }\end{array}$ & $10 / 21 / 2006$ & $<.064$ & $<.11$ & $<.031$ & $<.093$ & 0.18 & 0.20 & 0.17 & $<.12$ & 0.15 & $<.034$ \\
\hline $\begin{array}{l}\text { COMMERCIAL } \\
\text { ROOF-7 }\end{array}$ & $03 / 21 / 2007$ & $<.064$ & $<.11$ & 0.09 & 0.58 & 0.99 & 1.30 & 1.10 & 0.62 & 1.10 & $<0.12$ \\
\hline $\begin{array}{l}\text { COMMERCIAL } \\
\text { ROOF-8 }\end{array}$ & $04 / 02 / 2007$ & $<.064$ & $<.11$ & $<.031$ & 0.12 & 0.20 & 0.24 & 0.22 & $<.12$ & 0.19 & $<.034$ \\
\hline $\begin{array}{l}\text { COMMERCIAL } \\
\text { ROOF-9 }\end{array}$ & $04 / 22 / 2007$ & $<.064$ & $<.11$ & $<.031$ & 0.10 & 0.23 & 0.32 & 0.31 & 0.17 & 0.30 & $<.034$ \\
\hline
\end{tabular}


Table 1-6. Concentrations of PAH compounds and total PAH summation for commercial roof-Continued.

$[<$, less than; all values expressed as micrograms per liter; chemical nomenclature is that of the Wisconsin State Laboratory of Hygiene $]$

\begin{tabular}{|c|c|c|c|c|c|c|c|c|c|c|}
\hline Sample ID & Date & $\begin{array}{c}\text { Fluoran- } \\
\text { thene }\end{array}$ & Fluorene & $\begin{array}{c}\text { Indeno } \\
(1.2 .3-C, D) \\
\text { Pyrene } \\
\end{array}$ & $\begin{array}{c}\text { 1-Methyl- } \\
\text { naphthalene }\end{array}$ & $\begin{array}{l}\text { 2-Methyl- } \\
\text { naphthalene }\end{array}$ & Naphthalene & $\begin{array}{l}\text { Phenan- } \\
\text { threne }\end{array}$ & Pyrene & Total PAH \\
\hline $\begin{array}{l}\text { COMMERCIAL } \\
\text { ROOF-1 }\end{array}$ & 08/17/2006 & 0.38 & $<.52$ & 0.21 & $<.064$ & $<.049$ & $<.042$ & 0.15 & 0.31 & 1.88 \\
\hline $\begin{array}{l}\text { COMMERCIAL } \\
\text { ROOF-2 }\end{array}$ & 08/28/2006 & 0.12 & $<.52$ & $<.093$ & $<.064$ & $<.049$ & $<.042$ & $<.093$ & $<.11$ & 0.12 \\
\hline $\begin{array}{l}\text { COMMERCIAL } \\
\text { ROOF-3 }\end{array}$ & $10 / 04 / 2006$ & 0.54 & $<.52$ & 0.24 & $<.064$ & $<.049$ & $<.042$ & 0.23 & 0.43 & 2.40 \\
\hline $\begin{array}{l}\text { COMMERCIAL } \\
\text { ROOF-4 }\end{array}$ & $10 / 10 / 2006$ & 0.72 & $<.52$ & 0.27 & $<.064$ & $<.049$ & $<.042$ & 0.32 & 0.56 & 3.21 \\
\hline $\begin{array}{l}\text { COMMERCIAL } \\
\text { ROOF-5 }\end{array}$ & $10 / 16 / 2006$ & 0.46 & $<.52$ & 0.17 & $<.064$ & $<.049$ & $<.042$ & 0.23 & 0.37 & 2.15 \\
\hline $\begin{array}{l}\text { COMMERCIAL } \\
\text { ROOF-6 }\end{array}$ & $10 / 21 / 2006$ & 0.46 & $<.52$ & $<0.14$ & $<.064$ & $<.049$ & $<.042$ & 0.31 & 0.36 & 1.83 \\
\hline $\begin{array}{l}\text { COMMERCIAL } \\
\text { ROOF-7 }\end{array}$ & 03/21/2007 & 2.90 & $<.52$ & 1.00 & $<.064$ & $<.049$ & $<.042$ & 1.60 & 2.30 & 13.58 \\
\hline $\begin{array}{l}\text { COMMERCIAL } \\
\text { ROOF-8 }\end{array}$ & $04 / 02 / 2007$ & 0.53 & $<.52$ & 0.20 & $<.064$ & $<.049$ & $<.042$ & 0.28 & 0.42 & 2.40 \\
\hline $\begin{array}{l}\text { COMMERCIAL } \\
\text { ROOF-9 }\end{array}$ & $04 / 22 / 2007$ & 0.73 & $<.52$ & 0.31 & $<.064$ & $<.049$ & $<.042$ & 0.33 & 0.56 & 3.36 \\
\hline
\end{tabular}


Table 1-7. Concentrations of PAH compounds and total PAH summation for a mixed-use area (strip mall).

$[<$, less than; all values expressed as micrograms per liter; chemical nomenclature is that of the Wisconsin State Laboratory of Hygiene]

\begin{tabular}{|c|c|c|c|c|c|c|c|c|c|c|c|}
\hline Sample ID & Date & $\begin{array}{l}\text { Acenaph- } \\
\text { thene }\end{array}$ & $\begin{array}{l}\text { Acenaph- } \\
\text { thylene }\end{array}$ & Anthracene & $\begin{array}{c}\text { Benzo (A) } \\
\text { Anthracene }\end{array}$ & $\begin{array}{c}\text { Benzo (A) } \\
\text { Pyrene }\end{array}$ & $\begin{array}{c}\text { Benzo (B) } \\
\text { Fluoran- } \\
\text { thene }\end{array}$ & $\begin{array}{c}\text { Benzo } \\
(G, H, I,) \\
\text { Perylene }\end{array}$ & $\begin{array}{c}\text { Benzo (K) } \\
\text { Fluoran- } \\
\text { thene }\end{array}$ & Chrysene & $\begin{array}{l}\text { Dibenzo (A, } \\
\text { H) Anthra- } \\
\text { cene }\end{array}$ \\
\hline MIXED USE - 1 & $04 / 08 / 2008$ & $<.064$ & $<.11$ & $<.031$ & 0.22 & 0.49 & 1.10 & 1.00 & 0.49 & 0.82 & $<.15$ \\
\hline MIXED USE - 2 & 04/10/2008 & $<.064$ & $<.11$ & $<.094$ & 0.47 & 0.85 & 1.60 & 1.40 & 0.53 & 1.20 & $<.17$ \\
\hline MIXED USE - 3 & 05/29/2008 & $<.064$ & $<.11$ & $<.031$ & 0.09 & 0.18 & 0.25 & 0.25 & $<.12$ & 0.17 & $<.034$ \\
\hline MIXED USE - 4 & $06 / 05 / 2008$ & $<.064$ & $<.11$ & $<.031$ & 0.22 & 0.44 & 0.75 & 0.76 & 0.25 & 0.52 & $<.090$ \\
\hline MIXED USE - 5 & $06 / 12 / 2008$ & $<.064$ & $<.11$ & $<.031$ & 0.09 & 0.16 & 0.21 & 0.23 & $<.12$ & 0.15 & $<.034$ \\
\hline MIXED USE - 6 & $06 / 12 / 2008$ & $<.064$ & $<.11$ & $<.031$ & 0.09 & $<.16$ & 0.13 & $<.14$ & $<.12$ & 0.08 & $<.034$ \\
\hline MIXED USE - 7 & $06 / 22 / 2008$ & $<.064$ & $<.11$ & $<.031$ & 0.11 & 0.18 & 0.57 & 0.62 & 0.16 & 0.45 & $<.066$ \\
\hline MIXED USE - 8 & 07/07/2008 & $<.064$ & $<.11$ & $<.031$ & 0.09 & $<.16$ & 0.21 & 0.23 & $<.12$ & 0.15 & $<.034$ \\
\hline MIXED USE - 9 & 07/10/2008 & $<.064$ & $<.11$ & $<.031$ & 0.09 & $<.16$ & 0.21 & 0.23 & $<.12$ & 0.15 & $<.034$ \\
\hline MIXED USE - 10 & $07 / 11 / 2008$ & $<.064$ & $<.11$ & $<.031$ & 0.15 & 0.32 & 0.55 & 0.56 & 0.17 & 0.38 & $<.065$ \\
\hline MIXED USE - 11 & 07/19/2008 & $<.064$ & $<.11$ & $<.031$ & 0.09 & $<.16$ & $<.13$ & $<.14$ & $<.12$ & 0.04 & $<.034$ \\
\hline MIXED USE - 12 & 08/04/2008 & $<.064$ & $<.11$ & $<.060$ & 0.39 & 0.47 & 0.60 & 0.51 & 0.23 & 0.61 & $<.065$ \\
\hline MIXED USE - 13 & $08 / 13 / 2008$ & $<.064$ & $<.11$ & $<.031$ & 0.41 & 0.71 & 0.99 & 0.90 & 0.35 & 0.88 & $<.11$ \\
\hline MIXED USE - 14 & $08 / 08 / 2028$ & $<.064$ & $<.11$ & $<.031$ & 0.39 & 1.00 & 1.40 & 1.30 & 0.45 & 1.10 & $<.13$ \\
\hline MIXED USE - 15 & 09/04/2008 & $<.064$ & $<.11$ & $<.031$ & 0.45 & 0.91 & 1.60 & 1.40 & 0.51 & 1.40 & $<.16$ \\
\hline
\end{tabular}


Table 1-7. Concentrations of PAH compounds and total PAH summation for a mixed-use area (strip mall) —Continued.

$[<$, less than; all values expressed as micrograms per liter; chemical nomenclature is that of the Wisconsin State Laboratory of Hygiene]

\begin{tabular}{|c|c|c|c|c|c|c|c|c|c|c|}
\hline Sample ID & Date & $\begin{array}{c}\text { Fluoran- } \\
\text { thene }\end{array}$ & Fluorene & $\begin{array}{c}\text { Indeno } \\
\text { (1.2.3-C,D) } \\
\text { Pyrene }\end{array}$ & $\begin{array}{c}\text { 1-Methyl- } \\
\text { naphthalene }\end{array}$ & $\begin{array}{c}\text { 2-Methyl- } \\
\text { naphthalene }\end{array}$ & Naphthalene & $\begin{array}{c}\text { Phenan- } \\
\text { threne }\end{array}$ & Pyrene & Total PAH \\
\hline MIXED USE - 1 & $04 / 08 / 2008$ & 1.90 & $<.52$ & 0.83 & $<.064$ & $<.049$ & $<.042$ & 0.47 & 1.30 & 8.62 \\
\hline MIXED USE - 2 & $04 / 10 / 2008$ & 2.80 & $<.52$ & 1.40 & $<.064$ & $<.049$ & $<.042$ & 0.97 & 1.90 & 13.12 \\
\hline MIXED USE - 3 & $05 / 29 / 2008$ & 0.35 & $<.52$ & 0.23 & $<.064$ & $<.049$ & $<.042$ & $<.093$ & 0.24 & 1.76 \\
\hline MIXED USE - 4 & $06 / 05 / 2008$ & 1.10 & $<.52$ & 0.70 & $<.064$ & $<.049$ & $<.042$ & 0.36 & 0.82 & 5.92 \\
\hline MIXED USE - 5 & $06 / 12 / 2008$ & 0.31 & $<.52$ & 0.21 & $<.064$ & $<.049$ & $<.042$ & $<.093$ & 0.22 & 1.58 \\
\hline MIXED USE - 6 & $06 / 12 / 2008$ & 0.18 & $<.52$ & 0.13 & $<.064$ & $<.049$ & $<.042$ & $<.093$ & 0.13 & 0.74 \\
\hline MIXED USE - 7 & $06 / 22 / 2008$ & 0.79 & $<.52$ & 0.57 & $<.064$ & $<.049$ & $<.042$ & 0.26 & 0.50 & 4.21 \\
\hline MIXED USE - 8 & $07 / 07 / 2008$ & 0.28 & $<.52$ & 0.22 & $<.064$ & $<.049$ & $<.042$ & $<.093$ & 0.21 & 1.39 \\
\hline MIXED USE - 9 & $07 / 10 / 2008$ & 0.28 & $<.52$ & 0.22 & $<.064$ & $<.049$ & $<.042$ & $<.093$ & 0.21 & 1.39 \\
\hline MIXED USE - 10 & $07 / 11 / 2008$ & 0.72 & $<.52$ & 0.55 & $<.064$ & $<.049$ & $<.042$ & 0.25 & 0.53 & 4.18 \\
\hline MIXED USE - 11 & $07 / 19 / 2008$ & $<.11$ & $<.52$ & $<.095$ & $<.064$ & $<.049$ & $<.042$ & $<.093$ & $<.11$ & 0.14 \\
\hline MIXED USE - 12 & $08 / 04 / 2008$ & 2.20 & $<.52$ & 0.51 & $<.064$ & $<.049$ & $<.042$ & 0.52 & 1.50 & 7.54 \\
\hline MIXED USE - 13 & $08 / 13 / 2008$ & 2.50 & $<.52$ & 0.88 & $<.064$ & $<.049$ & $<.042$ & 0.82 & 1.70 & 10.14 \\
\hline MIXED USE - 14 & $08 / 08 / 2028$ & 2.50 & $<.52$ & 1.20 & $<.064$ & $<.049$ & $<.042$ & 0.52 & 1.80 & 11.66 \\
\hline MIXED USE - 15 & $09 / 04 / 2008$ & 3.70 & $<.52$ & 1.40 & $<.064$ & $<.049$ & $<.042$ & 1.20 & 2.20 & 14.77 \\
\hline
\end{tabular}


Table 1-7. Concentrations of PAH compounds and total PAH summation for a mixed-use area (strip mall)—Continued.

$[<$, less than; all values expressed as micrograms per liter; chemical nomenclature is that of the Wisconsin State Laboratory of Hygiene]

\begin{tabular}{|c|c|c|c|c|c|c|c|c|c|c|c|}
\hline Sample ID & Date & $\begin{array}{l}\text { Acenaph- } \\
\text { thene }\end{array}$ & $\begin{array}{l}\text { Acenaph- } \\
\text { thylene }\end{array}$ & Anthracene & $\begin{array}{c}\text { Benzo (A) } \\
\text { Anthracene }\end{array}$ & $\begin{array}{c}\text { Benzo (A) } \\
\text { Pyrene }\end{array}$ & $\begin{array}{c}\text { Benzo (B) } \\
\text { Fluoran- } \\
\text { thene }\end{array}$ & $\begin{array}{c}\text { Benzo } \\
(\mathrm{G}, \mathrm{H}, \mathrm{I},) \\
\text { Perylene }\end{array}$ & $\begin{array}{c}\text { Benzo (K) } \\
\text { Fluoran- } \\
\text { thene }\end{array}$ & Chrysene & $\begin{array}{c}\text { Dibenzo (A, } \\
\text { H) Anthra- } \\
\text { cene }\end{array}$ \\
\hline MIXED USE - 16 & $09 / 08 / 2008$ & $<.064$ & $<.11$ & $<.031$ & 0.12 & 0.30 & 0.54 & 0.46 & 0.18 & 0.47 & $<.056$ \\
\hline MIXED USE - 17 & $09 / 12 / 2008$ & $<.064$ & $<.11$ & $<.031$ & 0.13 & 0.28 & 0.63 & 0.49 & 0.20 & 0.62 & $<.059$ \\
\hline MIXED USE - 18 & $10 / 07 / 2008$ & $<.064$ & $<.11$ & $<.031$ & 0.38 & 1.20 & 1.70 & 1.70 & 0.52 & 1.30 & $<.16$ \\
\hline MIXED USE - 19 & $10 / 15 / 2008$ & $<.064$ & $<.11$ & $<.031$ & 0.15 & 0.56 & 0.80 & 0.78 & 0.25 & 0.65 & $<.078$ \\
\hline
\end{tabular}

Table 1-7. Concentrations of PAH compounds and total PAH summation for a mixed-use area (strip mall)—Continued.

$[<$, less than; all values expressed as micrograms per liter; chemical nomenclature is that of the Wisconsin State Laboratory of Hygiene]

\begin{tabular}{|c|c|c|c|c|c|c|c|c|c|c|}
\hline Sample ID & Date & $\begin{array}{c}\text { Fluoran- } \\
\text { thene }\end{array}$ & Fluorene & $\begin{array}{c}\text { Indeno } \\
(1.2 .3-C, D) \\
\text { Pyrene }\end{array}$ & $\begin{array}{c}\text { 1-Methyl- } \\
\text { naphthalene }\end{array}$ & $\begin{array}{c}\text { 2-Methyl- } \\
\text { naphthalene }\end{array}$ & Naphthalene & $\begin{array}{l}\text { Phenan- } \\
\text { threne }\end{array}$ & Pyrene & Total PAH \\
\hline MIXED USE - 16 & 09/08/2008 & 1.20 & $<.52$ & 0.47 & $<.064$ & $<.049$ & $<.042$ & 0.31 & $<.70$ & 4.05 \\
\hline MIXED USE - 17 & $09 / 12 / 2008$ & 1.50 & $<.52$ & 0.55 & $<.064$ & $<.049$ & $<.042$ & 0.48 & 0.84 & 5.72 \\
\hline MIXED USE - 18 & $10 / 07 / 2008$ & 3.10 & $<.52$ & 1.50 & $<.064$ & $<.049$ & $<.042$ & 0.82 & 2.00 & 14.22 \\
\hline MIXED USE - 19 & $10 / 15 / 2008$ & 1.50 & $<.52$ & 0.71 & $<.064$ & $<.049$ & $<.042$ & 0.47 & 0.91 & 6.78 \\
\hline
\end{tabular}



